\title{
A LONGITUDINAL ANALYSIS OF \\ PHYSICAL ACTIVITY AND OVERWEIGHT/OBESITY IN ADOLESCENTS IN SASKATOON
}

A Thesis Submitted to the College of Graduate Studies and Research

In Partial Fulfillment of the Requirements for the

Degree of Masters of Science in the

Department of Community Health and Epidemiology

University of Saskatchewan

Saskatoon

By

Hang T. K. Lai

(C) Copyright Hang T. K. Lai, April 2008. All Rights Reserved. 


\section{PERMISSION TO USE STATEMENT}

In presenting this thesis in partial fulfillment of the requirements for a Postgraduate degree from the University of Saskatchewan, I agree that the Libraries of this University make it freely available for inspection. I further agree that permission for copying of this thesis in any manner, in whole or in part, for scholarly purposes may be granted by the professor or professors who supervised my thesis work, or, in their absence, by the Head of the Department of the Dean of the College in which my thesis was done. It is understood that any copying or publication or use of this thesis or parts thereof for financial gain shall not be allowed without my written permission. It is also understood that due recognition shall be given to me and to the University of Saskatchewan in any scholarly use which may be made of any materials in my thesis.

Requests for permission to copy or to make use of material in this thesis in whole or part should be addressed to:

Head of the Department of Community Health \& Epidemiology

University of Saskatchewan

107 Wiggins Road

Saskatoon, Saskatchewan

S7N 5E5 


\begin{abstract}
Overweight and obesity, one of the most common public health problems in affluent societies, have become epidemic not only in Canada but also throughout the world. Obesity is also a major contributor to the global burden of chronic disease and disability such as diabetes, hypertension, and cardiovascular disorders.
\end{abstract}

Studies have demonstrated clearly that higher intake of cholesterol and saturated fats and generally higher intake of energy-dense food are a key determinant of increasing levels of obesity and overweight in children. Physical activity is also recognized as a major factor in preventing obesity among children. Environmental factors - by which we mean both social (such as social support, social networks) and physical environment (such as access to physical activity amenities, roads and trails, grocery stores) - in generally believed to have a powerful influence on either limiting or enhancing the effects of fundamental determinants (diet and physical activity) of obesity in children. This thesis focuses on one of the key determinants, physical activity, and in turn examines factors that are related to changing physical activity in children.

This research was designed to examine two major questions: (1) How do physical activity and overweigh/obesity change over time in a cohort of adolescents in Saskatoon? Are there differences in the patterns of change in overweight/obesity and physical activity between boys and girls? (2) What are the effects of family/friends and physical environments on the changing patterns of physical activity in this sample? 
The data used in this study was taken from the in motion studies' longitudinal data. Study participants include 837 adolescents from12-18 years of age from two high schools and five elementary schools from two diverse geographic areas in Saskatoon (low and high socioeconomic status). Physical activity patterns of adolescents were investigated over a five-month period (e.g., type, frequency, and duration). Participants were also asked to respond to questions on demographics, social support, perceived benefits and barriers of physical activity, and health practices.

The results of this study indicated that overweight/obesity increased with age, while physical activity decreased with age for both boys and girls. Boys overall were more likely to be physically active than were girls. Adolescents who received greater direct support from family members were $21 \%$ more likely to sustain their physical activity levels (relative odds $1.21 ; 95 \%$ CI 1.17, 1.24); in contrast, the more the family's indirect support the 5.4\% less sustaining were the adolescents' physical activity (relative odds $0.94 ; 95 \%$ CI $0.91,0.98)$. Home environments which were 'rich' in resources relevant to physical activity had $4 \%$ greater influence on adolescents' physical activity levels, and this relationship was stronger than that of the influence of living in certain neighbourhoods (relative odds 1.04; 95\% CI 1.03, 1.05).

This research shed some greater understanding of the impact of family's support and physical environment factors on adolescents' continued physical activity levels. The implications of results for further research, targeted programs, and social policy is discussed in the thesis. 


\section{ACKNOWLEDGEMENTS}

I would like to acknowledge and express my gratitude to the people who contributed to the successful completion of this research. First and foremost, I would like to express my deepest appreciation and gratitude to my supervisor—Dr. Nazeem Muhajarine — for his encouragement and support to me throughout this study program, and for his constant guidance, helpful feedback and patience throughout the research program.

I also would like to acknowledge the contributions of committee members-Dr. Karen Chad, and Dr. Bonnie Janzen—for their comments during committee meetings and during the revision of this thesis. I would like to especially thank Dr. Karen Chad for her helpful comments on my thesis, for her encouragement and support to complete my thesis.

I would like to thank the external examiner-Dr. Adam Baxter-Jones—-for his helpful comments and careful review to significantly improve the quality of my thesis.

I would also like to thank all faculty members, secretaries and friends in the Department of Community Health and Epidemiology for their help, support and friendship.

Finally, I wish to express a depth of gratitude to my family and friends who were patient and supportive of my return to university. To my beloved husband-Hai Phamwho is always there for me to love, encourage, and support during my program. To my son-Anh Pham — who always love and help me to relieve stress during my studies. To

my parents and sisters who provided much needed support. And to my friend— $-\mathrm{Lan} \mathrm{Vu}-$ for her help, understanding and encouragement. 
This thesis research was supported through a strategic training award from the Community and Population Health Research (CPHR) Training Program (a CIHR Strategic Training in Health Research program), courtesy of the Saskatchewan Population Health Evaluation Research Unit (SPHERU). This source of financial support is gratefully acknowledged. 


\section{TABLE OF CONTENTS}

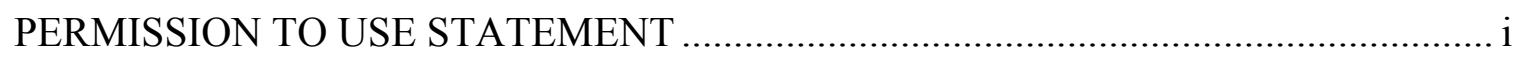

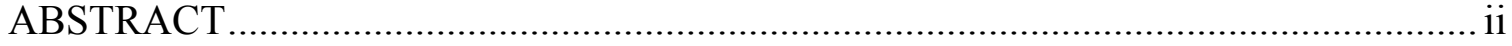

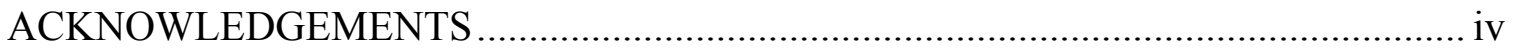

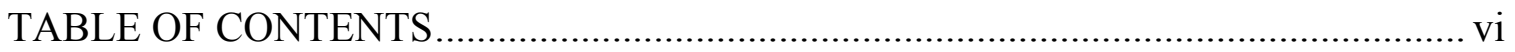

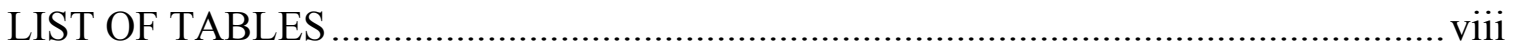

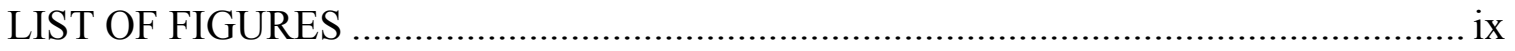

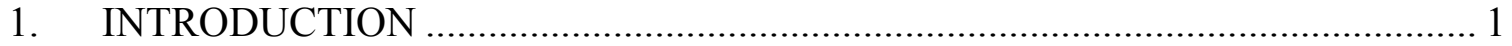

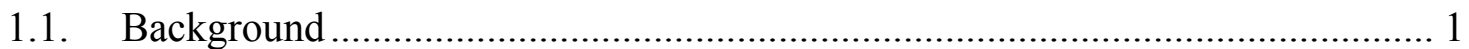

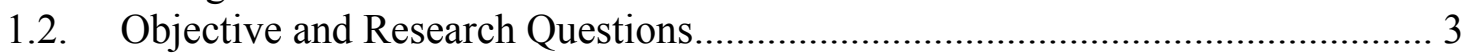

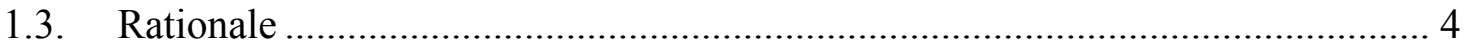

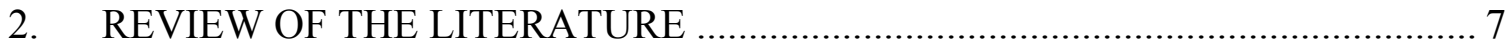

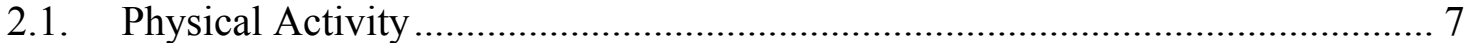

2.1.1. Definition of Physical Activity ............................................................... 7

2.1.2. Indicators Used to Measure Physical Activity .............................................. 7

2.1.3. Benefits of Physical Activity .................................................................. 8

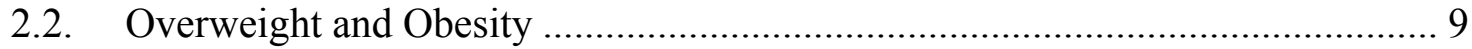

2.2.1. Definition of Overweight and Obesity in Children...................................... 9

2.2.2. Measures and International Standards for Childhood Overweight and

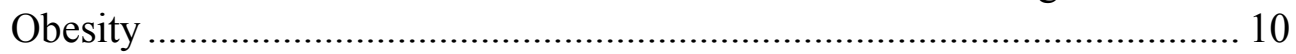

2.2.3. Prevalence of Childhood Overweight and Obesity ...................................... 12

2.3. Determinants of Physical Activity and Overweight/Obesity among

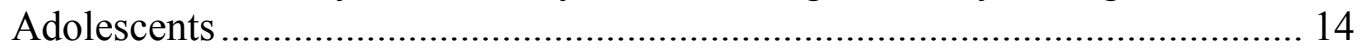

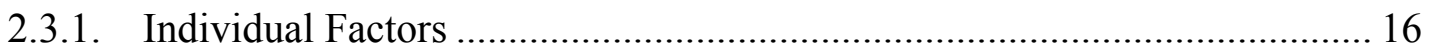

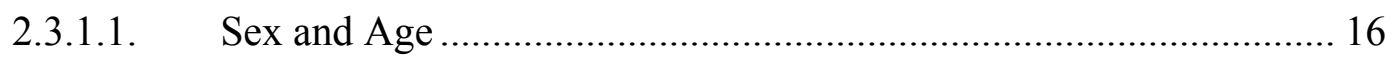

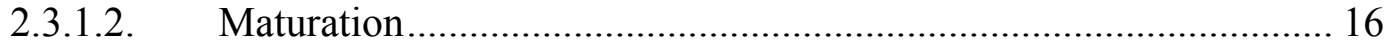

2.3.1.3. Attitudes/beliefs ...................................................................... 17

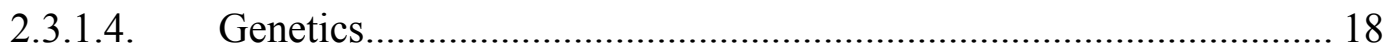

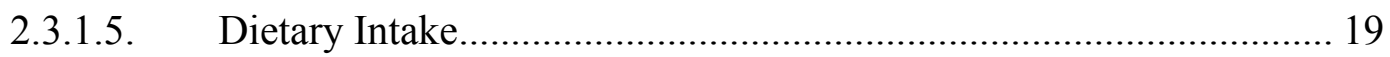

2.3.1.6. Socio-demographic Background...................................................... 20

2.3.1.7. Sedentary Behaviors and Physical Inactivity.................................... 22

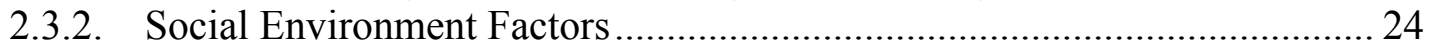

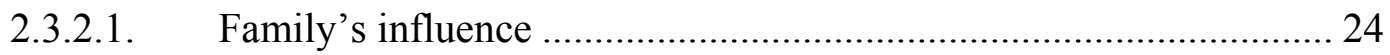

2.3.2.2. Support from Parents and Peers ......................................................... 26

2.3.3. Physical Environment Factors …………………..................................... 27

2.3.3.1. Home Environment .................................................................. 28

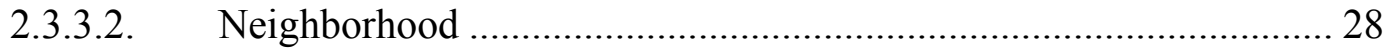

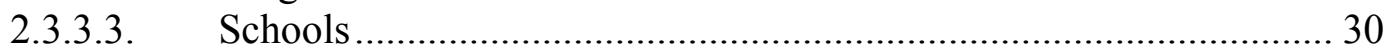

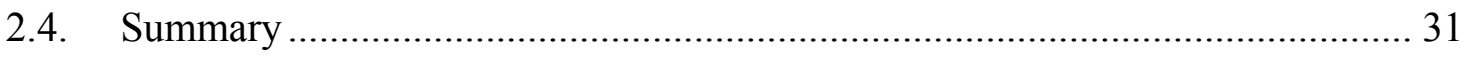

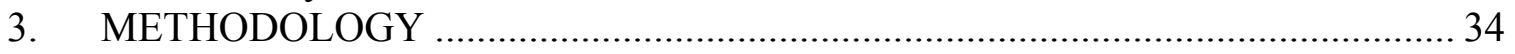

3.1. Study Design ...................................................................................... 34

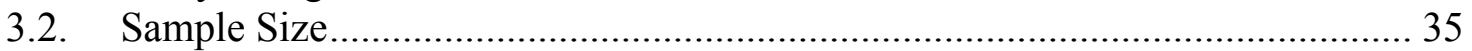

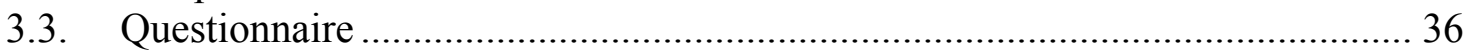

3.3.1. Physical Activity Questionnaire ............................................................... 36 
3.3.2. Physical Activity Determinants Questionnaire .............................................. 36

3.4. Ethics Approval and Confidentiality ………………....................................... 37

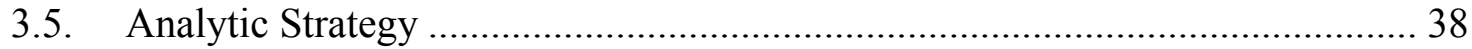

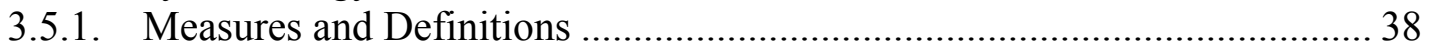

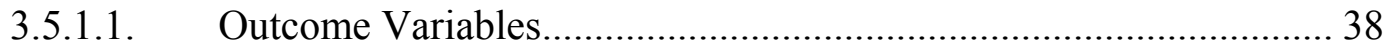

3.5.1.2. Independent Variables ....................................................................... 39

3.5.2. Methods of Analysis ................................................................................. 44

3.5.2.1. Characteristics of the Study Population ........................................... 44

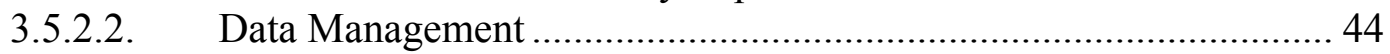

3.5.2.3. Statistical Analysis..................................................................... 45

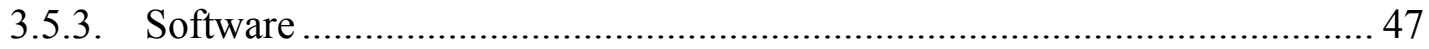

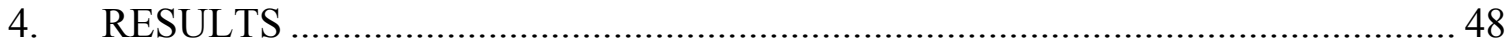

4.1. Characteristics of the Study Population ............................................................ 48

4.2. Derived Variable Constructs......................................................................... 50

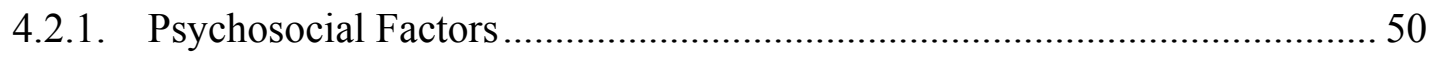

4.2.2. Benefits of and Barriers to Physical Activity ............................................ 52

4.2.3. Support from Family and Friends ............................................................ 55

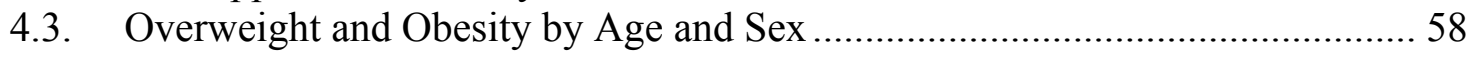

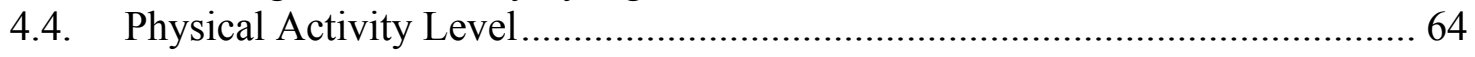

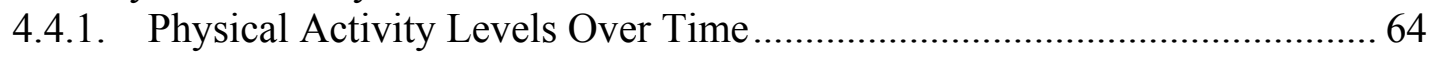

4.4.2. Physical Activity Trends by Age and Sex ................................................. 65

4.4.3. Distribution of the Total Daily Energy Expenditure by Sex over Five Time

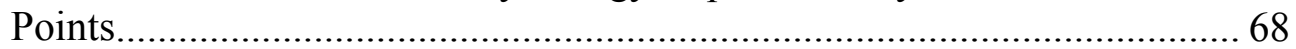

4.5. Bivariate Associations: Physical Activity and Independent Variables .............. 70

4.6. Determinants of Changing Physical Activity Patterns..................................... 74

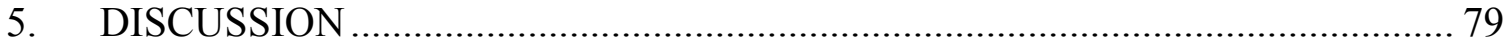

5.1. Physical Activity, Overweight/Obesity Patterns Over Time, and by Sex ......... 79

5.2. Determinants of Changing Physical Activity Patterns........................................ 84

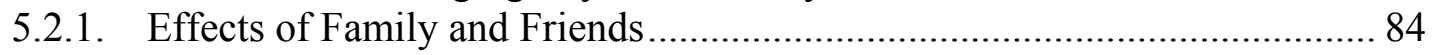

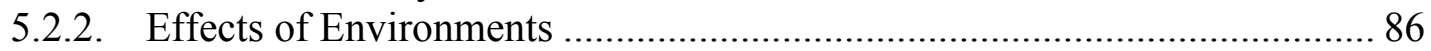

5.2.3. Implications for Physical Activity Intervention.......................................... 87

5.3. Methodological Issues: Strengths and Limitations ............................................. 88

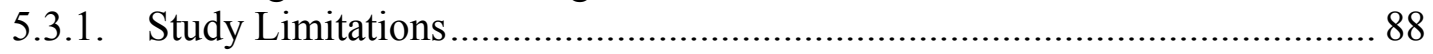

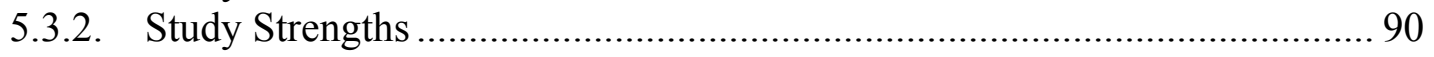

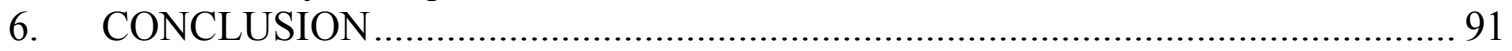

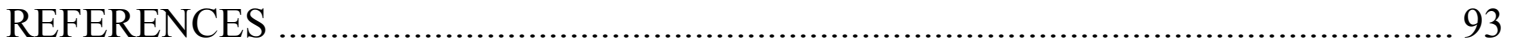

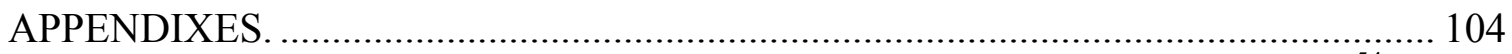

Appendix A. BMI Values for Overweight and Obesity Proposed by Cole et al. $.^{54} \ldots . .104$

Appendix B. Physical Activity Questionnaire ………………………...................... 105

Appendix C. Physical Activity Determinants Questionnaire. …….............................. 109

Appendix D. Ethical Approval ........................................................................... 121 


\section{LIST OF TABLES}

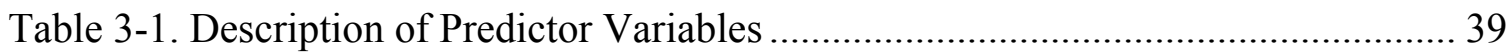

Table 4-1. Demographic Characteristics of the Study Population.................................. 48

Table 4-2. Factor Analysis Results for Psychosocial domain........................................ 51

Table 4-3. Factor Analysis Results for Benefits of and Barriers to Physical Activity ..... 54

Table 4-4. Factor Analysis Results for Family's Support and Friends' Support .............. 57

Table 4-5. Mean BMI and Proportion of Overweight/Obesity by Age and Sex at Time 1

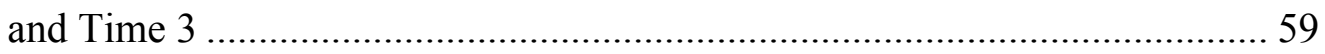

Table 4-6a \& b. Comparison of BMI between Age groups for girls and boys................ 61

Table 4-7a \& b. Chi-square test results for Overweight/Obesity status by Sex and Age

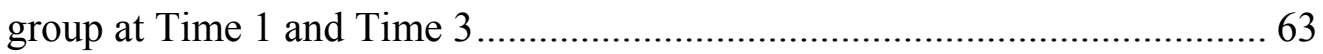

Table 4-8. Proportion (\%) of Adolescents' Physical Activity Levels at Five Time Points64

Table 4-9. Proportion (\%) of Adolescents with Low, Moderate and High Physical

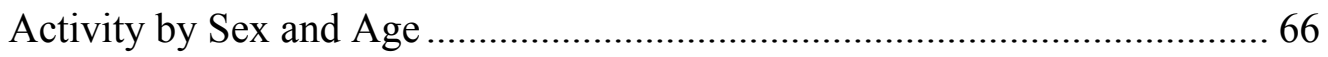

Table 4-10. Total Energy Expenditure (Mean KKD) by Sex at Five Time Points........... 68

Table 4-11. Comparison of Total Energy Expenditure Scores Between Boys and Girls (ttest) Over Five Time Points

Table 4-12. Bivariate Analysis Results Examining Association Between Physical Activity and Predictor Variables

Table 4-13. Factors Associated with High Level of Physical Activity Over Time in Adolescents in Saskatoon 75

Table 4-14. Final Main Effect Model Examining Factors Associated with High Physical Activity Over Time in Adolescents in Saskatoon....................................... 78

Table 5-1. Prevalence of Overweight and Obesity in the 1978/79 CHS, 2004 CCHS and the Current Study 80 


\section{LIST OF FIGURES}

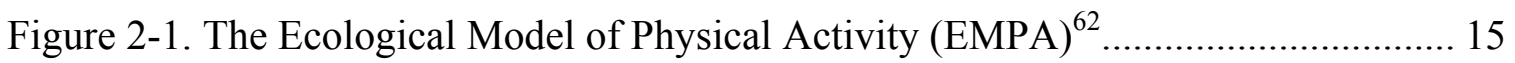

Figure 3-1. Description of the Study Design ............................................................. 35

Figure 4-1. Distribution of Overweight/Obesity at Time 1 and Time 3 ......................... 60

Figure 4-2. Proportion (\%) of Adolescents' Physical Activity Levels at Five Time Points

Figures 4-3a-c. Distribution of Low, Moderate, and High Physical Activity Among Adolescents By Sex and Age Group.......................................................6 67

Figure 4-4. Distribution of Total Energy Expenditure (KKD) Over Five Time Points.... 69 


\section{INTRODUCTION}

\subsection{Background}

Overweight and obesity, one of the most common public health problems in affluent societies, have become epidemic not only in Canada but also throughout the world. The prevalence of obesity is also increasing rapidly in many developing nations worldwide. It is estimated that over 1 billion adults are overweight in the world and at least 300 million of them are obese. ${ }^{1}$ There are 22 million children under five years old who are overweight worldwide. ${ }^{1}$

The National Population Health Survey of Canada in 1994-1995 indicated that $30.5 \%$ of those aged 20-64 years are obese. ${ }^{2}$ Between 1970 and 1992, among Canadians between the ages of 20 and 69 those were classified as obese (defined as BMI $\geq 30$ $\mathrm{kg} / \mathrm{m}^{2}$ ) increased from $8 \%$ to $13 \%$ in men and $13 \%$ to $15 \%$ in women. ${ }^{3}$ Over the same period, the prevalence of overweight (defined as BMI $25-29.9 \mathrm{~kg} / \mathrm{m}^{2}$ ) Canadians in the same age group increased from $47 \%$ to $58 \%$ in men and from $34 \%$ to $41 \%$ in women. ${ }^{3}$ In $1978-1979$, only $3 \%$ of children aged 2 to 17 were obese. By 2004 , this proportion increased to $8 \%$ (an estimated 500,000 children). ${ }^{4}$

Obesity is also a major contributor to the global burden of chronic disease and disability such as diabetes, hypertension, and cardiovascular disorders. ${ }^{1,5}$ More importantly, there is increasing evidence that childhood obesity, particularly in adolescence, is a risk factor for adult obesity. ${ }^{6}$ Obesity and its associated metabolic 
consequences are major impediments to quality of life. ${ }^{7}$ For all these reasons, obesity must be considered an important public health issue facing Canadians today.

Obesity is defined as a state of imbalance between calories ingested versus calories expended which would lead to excessive or abnormal fat accumulation. ${ }^{8}$ Studies have indicated that obesity is caused by a complex set of interactions involving genetic, diet, activity levels and environmental factors. ${ }^{9}{ }^{10}$ However, when one considers the genetic pool, it has not change dramatically within one or two generations, ${ }^{11}$ leading some to assert that at a population level, changes in diet, physical activity and environment are likely the key factors that have contributed to an increase in overweight and obesity prevalence seen in recent years. ${ }^{12-14}$

Studies have demonstrated clearly that higher intake of cholesterol and saturated fats and generally higher intake of energy-dense food are a key determinant of increasing levels of obesity and overweight in children. ${ }^{15,16}$ Physical activity is also recognized as a major factor in preventing obesity among children. ${ }^{17,}{ }^{18}$ Environmental factors—by which we mean both social (such as social support, social networks) and physical environment (such as access to physical activity amenities, roads and trails, grocery stores) - in generally believed to have a powerful influence on either limiting or enhancing the effects of fundamental determinants (diet and physical activity) of obesity in children. This thesis focuses on one of the key determinants, physical activity, and in turn examines factors that are related to changing physical activity in children. It does not however focus on dietary behaviour in children which is outside the scope of this particular investigation. 


\subsection{Objective and Research Questions}

The primary objective of this study was to examine the relationship between physical activity over time and: a) adolescent's overweight/obesity, b) intrapersonal factors, social and physical environment factors. The research will address the following questions:

1) How do physical activity and overweigh/obesity change over time in a cohort of adolescents in Saskatoon? Are there differences in the patterns of change in overweight/obesity and physical activity between boys and girls?

Hypothesis (1a): Among adolescents, increases in physical activity and overweight/obesity will be similar among boys and girls.

Hypothesis (1b): Trends will be different for various age groups from 12 to 18 years of age among boys and girls.

2) What are the effects of socio demographic, psychosocial, family/friends and physical environments on the changing patterns of physical activity in this sample?

Hypothesis (2a): Socio demographic and psychosocial have effects on the changing patterns of physical activity in adolescents in this study.

Hypothesis (2b): Family/friends have effects on the changing patterns of physical activity in adolescents in this survey. 
Hypothesis (2c): Physical environments have effects on the changing patterns of physical activity in adolescents in this survey.

The following approaches were used to answer the research questions:

1) Calculate the proportion of physical activity levels and prevalence of overweight and obesity among adolescents in this study sample. Identify the differences in the patterns of change in overweight/obesity and physical activity between boys and girls over time.

2) Build multivariate model to examine the association between physical activity levels among adolescents and intrapersonal level, social and physical environment.

\subsection{Rationale}

The prevalence of obesity among adults, children and adolescents is increasing in industrial countries and has serious negative medical and psychosocial consequences. ${ }^{19}$ The rising prevalence of childhood obesity has been attributed to increased caloric content of the diet, decreased levels of physical activity, and increasingly sedentary lifestyles. ${ }^{5}$

Studies have also suggested that environmental factors such as family, school, and neighborhood may play an important role in shaping individual behavior and lifestyle choice, which in turn have impact on childhood obesity. Environmental factors are considered as one of the most important contributors to the rapid increase in the prevalence of overweight. ${ }^{12}$ According to the World Health Organization (WHO), "the 
fundamental causes of the obesity epidemic are societal, resulting from an environment that promote sedentary lifestyles and the consumption of high-fat, energy-dense diets. ${ }^{20}$ Physical and social environments shape child and adolescent behaviors because most children spend a large part of their day in settings that are susceptible to change such as home, school, transportation between home and school, and after-school programs. ${ }^{21}$ There is general agreement that the obesity epidemic is largely associated with an environment that promotes excessive food intake and discourages physical activity. ${ }^{22}$ However, there remains a great need to understand how environmental factors can affect behaviors and eventually body weight regulation. ${ }^{11,22}$

One's family and peer are also said to be critically important in the development of children's involvement in physical activity and other health-related behaviours. ${ }^{23}$ The home environment is a critical factor in the development of childhood obesity. Family members are a major source of influence that affects the behavior and lifestyle of children. ${ }^{24-26}$ Studies show that there is a strong correlation between the health behaviors of parents and those of their children. Several studies report the influence of parents and peers on physical activity in young adolescents. The Butcher's study showed that encouragement from significant others was consistently associated with participation in various kinds of physical activity among adolescent girls. ${ }^{27}$ Other studies have found that the effects from parents and friends were the most important socialization agents toward participation in physical activity in adolescents. ${ }^{28,29}$

Since obesity is caused by complex interactions among genetic endowment, diet, behavior, activity level and environment, ${ }^{9}$ there is a need to understand the relationships between physical activity and physical environment factors more specifically, and 
family/friends' influence on the risk of overweight and obesity in adolescents. Many studies have identified factors that may influence the physical activity levels of children, ${ }^{30-32}$ however knowledge in this area is still rudimentary. Furthermore, there are gaps in research on the role of environment factor to the development of childhood obesity and the relationships between physical activity levels and childhood obesity. ${ }^{33}$

Therefore, more studies are necessary to provide in-depth information about the mechanism of environmental factors on childhood physical activity, the relationships between physical activity and weight status in children. 


\section{REVIEW OF THE LITERATURE}

\subsection{Physical Activity}

\subsubsection{Definition of Physical Activity}

Physical activity has been defined as "any bodily movement produced by skeletal muscles that result in an expenditure of energy". ${ }^{34}$ Physical activity can be categorized

depending on type, intensity, and purpose. ${ }^{34}$ Physical activity is closely related to exercise and physical fitness, and sometimes are used interchangeably, but they have distinct definitions. Exercise is defined as "planned, structured, and repetitive bodily movement done to improve or maintain one or more components of physical fitness. ${ }^{, 34}$ Physical fitness is "a set of attributes that people have or achieve that relates to the ability to perform physical activity.",34

\subsubsection{Indicators Used to Measure Physical Activity}

According to the Canadian Fitness and Lifestyle Research Institute, the classification of physical activity levels of adults and youth was based on energy expenditure in all non-work, non-chore activity. ${ }^{35}$ A classification of active represents an average daily energy expenditure of at least 3 kilocalories per kilogram (KKD) of body weight during the previous 12 months. Moderately active represents average energyexpenditure values that are greater than 1.5 and less than 3.0 KKD. Inactive corresponds to average energy-expenditure values of less than or equal to $1.5 .^{35}$ In 1994 , Corbin et al., had suggested an energy expenditure level of 6-8 KKD as the range in which youth and adolescents will achieve health benefits. ${ }^{36}$ 
In this study, the in motion chose to use the more conservative criterion of greater than $8 \mathrm{KKD}$ for two reasons. First, the use of a more conservative cut point compensates for potential errors in over-reporting that may occur in self-reporting of physical activity $^{37}$ and second, it is in keeping with national standards for reporting physical activity for health benefits among youth and adolescents. ${ }^{38}$

\subsubsection{Benefits of Physical Activity}

Epidemiologic studies have shown that low level of physical activity are associated with markedly increased all-cause mortality rates. ${ }^{39-41}$ The US Surgeon General's Report on Physical Activity and Health (1996) confirmed that the higher levels of regular physical activity are associated with lower mortality rates for both older and younger adults. ${ }^{34}$ Physical activity has been associated with the wide range of beneficial health outcomes, including halving the risk of developing or dying from coronary heart disease, colon cancer; reducing the risk of type 2 diabetes, osteoporosis, and high blood pressure; and improving lipid profile and mental health. ${ }^{34}$ Physical activity can also improve musculoskeletal health, control body weight, and reduce symptoms of depression. $^{42}$

\section{- Economic Benefits of Physical Activity}

The economic benefits of physical activity include reducing health care costs, improving physical and social environments. According to $\mathrm{WHO}$ and $\mathrm{CDC}$, an investment of US\$1 on time and equipment for physical activity leads to saving of US\$3.2 in medical cost. ${ }^{43}$ The average annual direct medical costs are US\$1,019 for 
those who are regularly physically active compared with US\$1,349 for those who report being physically inactive. ${ }^{44}$

\section{- Economic Cost of Physical Inactivity}

The financial burden of physical inactivity is considerable. According to Katzmarzyk et al, ${ }^{39}$ a $10 \%$ reduction in the prevalence of physical inactivity in Canada has the potential to reduce direct health care expenditures by $\$ 150$ million each year.

In 1995 , the costs associated with inactivity and obesity accounted for $9.4 \%$ of the national USA health expenditure. In 2000, inactivity accounts for about $\$ 75$ billion of US medical costs, and in Canada physical inactivity has contributed to $6 \%$ of total health care costs. $^{42}$ In 1999 about 2.1 billion or $2.5 \%$ of total direct medical costs in Canada (i.e. hospital care, drugs, and research) were attributed to physical inactivity. ${ }^{39}$ In 2001 , the economic burden of physical inactivity was $\$ 5.3$ billion, of this $\$ 1.6$ billion on direct costs and $\$ 3.7$ billion on indirect costs. ${ }^{45}$

\subsection{Overweight and Obesity}

\subsubsection{Definition of Overweight and Obesity in Children}

According to Centers for Disease Control and Prevention "Overweight and obesity result from an energy imbalance, which involves eating too many calories and not getting enough physical activity". 46 The terms "overweight" and "obesity" refer to a person with an excess of body weight. Overweight is having extra body weight from muscle, bone, and fat. Obesity is having a high amount of extra body fat. ${ }^{47,48}$

Body Max Index (BMI) is used as the most useful measure to determine if a person is overweight or obese. If adults have a BMI of 25-29.9, they are considered 
overweight and are at an increased risk of developing health problems. Adults with a BMI of 30 or more are considered obese and are at a high to extremely high risk of developing health problems. ${ }^{49}$

\subsubsection{Measures and International Standards for Childhood Overweight and Obesity}

Body Max Index (BMI) was developed by Lambert Adolphe Jacques Quetelet, a Belgian mathematician, in the last century.${ }^{50}$ It is calculated as the weight in kilograms divided by the square of the height in meters $(\mathrm{kg} / \mathrm{m} 2)$. Currently, this anthropometry method, based on weight and height measures, is one of the commonly used tools to

screen for obesity and detect people at higher risk for nutritional or health disorders. ${ }^{51}$

In this tool, weight is considered one indicator of fatness. However children of the same weight but at different on development height can have widely different levels of adiposity. BMI, therefore, adjusts for varying heights. ${ }^{52}$ Thus, BMI is not a perfect measure in children because it covaries with height, but it was selected because it is an easy measure of body fat that is reproducible and valid. ${ }^{53}$

BMI is calculated using the same formula for children and adolescents. But in children the thresholds for BMI are not the same as in adults, and vary by the age and sex of the child. In 2000, through an international survey conducted by Cole and colleagues, the BMI cut-off values for overweight and obesity were calculated on the basis of height and weight measurements for about 100,000 children in six large countries: Brazil, Great Britain, Hong Kong, the Netherlands, Singapore and the United States. ${ }^{54}$ Childhood 
obesity standards limit by sex and age proposed by Cole et al. are commonly referred to as the international standards (Appendix A).

Another common reference that is currently used for evaluating the risk of overweight and obesity in children is a set of growth charts developed by the US Centers for Disease Control and Prevention (CDC). By using this standard, overweight and obese status in children is defined on the basis of age-specific percentiles of BMI. Therefore, it is important to use a BMI calculator especially for kids, and also use what is called the BMI percentile chart. The classification using CDC-BMI measure for children is as follows:

- BMI at or below the 5th percentile: Underweight

- BMI between 5th and 85th percentile: Healthy Weight

- BMI at or above the 85th percentile: Overweight

- BMI at or above the 95th percentile: Obesity

In this study, overweight and obesity status were defined using the international age- and sex-specific cutoffs developed by Cole et al. ${ }^{54}$ This proposed cutoff points are less arbitrary and more internationally based than other alternatives, and it also provides internationally comparable prevalence rates of overweight and obesity in children. ${ }^{54}$

Although BMI is a useful tool to monitor people's overweight/obese status, it also has its limitations. BMI measures total body weight, not the actual amount of fat a person is carrying. Some people have a BMI that is in the overweight category, but in fact much of their weight is due to muscle mass or a heavier bone structure rather than excess fat. Conversely, some athletes may be classified as underweight according to their 
BMI. This is due to low percentage of body fat, which may develop naturally as a result of their metabolic levels or particular activities they participate in. Those with a BMI which falls within the normal range does not necessarily indicate that they are in perfect health. They may be carrying more body fat than is good for them. One of the limitations of BMI is it may overestimate the risk of individuals with greater lean muscles mass and underestimate risk of individuals with less lean muscles mass. ${ }^{55}$ Therefore, BMI is not a good measure of body fat. It is reasonably good measure of overweight/obesity at a population level but is not a good measure in clinical settings.

\subsubsection{Prevalence of Childhood Overweight and Obesity}

In the past few decades, the prevalence of overweight and obesity have reached epidemic levels in many developed countries. ${ }^{56}$ In Canada, there is consistence evidence that the prevalence of childhood overweight and obesity have increased dramatically over the past two decades. ${ }^{57,58}$ Since 1981, the BMI of Canadian children has increased with the rate of almost $0.1 \mathrm{~kg} / \mathrm{m}^{2}$ per year for both sexes and most ages, indicating a consistent increased trend in BMI among children. ${ }^{58}$

Between 1981 and 1996, the prevalence of overweight among boys from 7 to 13 years old increased from $15 \%$ to $28.8 \%$; and among girls of the same age the prevalence rose from $15 \%$ to $23.6 \%{ }^{58}$ Over that period, the prevalence of obesity in children of the same age increased from 5\% to $13.5 \%$ for boys and $11.8 \%$ for girls. ${ }^{58}$ In 1996 the reported prevalence of overweight in Canadian children aged 7 to 13 ranged from $23 \%$ to $36 \%$, and in every province the rate has at least doubled since $1981.57,59$ 
In 1994-1995, 16\% of Canadian children aged 2 to 11 were considered obese, by $1998-1999$, this prevalence increased to $18 \%{ }^{60}$ According to the National Longitudinal Survey of Children and Youth (NLSCY) in 1994-1999, approximately 25\% of children aged 2 to 5 years were obese, compared with $10 \%$ of children aged 8 to 11 years; more than one-third of Canadian children aged 2 to 11 years were overweight in 1998-1999, and about half of those were considered obese. ${ }^{60}$ According to the data from the 1981 Canada Fitness Survey and the 1996 National Longitudinal Survey of Children and Youth, the prevalence of overweight and obesity among Canadian boys and girls ages 7 to 13 years were $11.9 \%$ in 1981 and $25.7 \%$ in $1996 .{ }^{59}$

\section{- Medical costs attributable to obesity in Canada}

In Canada, in 1997, the total direct cost due to obesity was over $\$ 1.8$ billion, equivalent to $2.4 \%$ of the total health care expenditure for all diseases for that year. ${ }^{61}$ In 2001 , the direct medical costs attributable to adult obesity was $\$ 1.6$ billion, whereas the indirect medical costs was $\$ 2.7$ billion. ${ }^{45}$ Therefore the total impact of obesity on the Canadian economy was $\$ 4.3$ billion in 2001, representing 2.2\% of the total health care expenditures (\$201.3 billion). ${ }^{3,45}$ 


\subsection{Determinants of Physical Activity and Overweight/Obesity among Adolescents}

According to the ecological model of physical activity (Figure 2-1) developed by Spence and Lee ${ }^{62}$, physical activity is influenced by three domains: intrapersonal (e.g., genetics, behavioral influence), social (e.g., family, friends, influence of others' beliefs and practices) and environmental (e.g., facilities, neighborhoods). On the congressional briefing of the United States Government Accountability Office in 2006, the factors affecting physical activity are grouped into three categories as well: demographic factors (SES, and race/ethnicity), cognitive and behavioral factors (attitudes, beliefs, and perceptions, family and social influences, and sedentary behaviors), and community factors (safety, built environment, and physical activity facilities). ${ }^{63}$ 


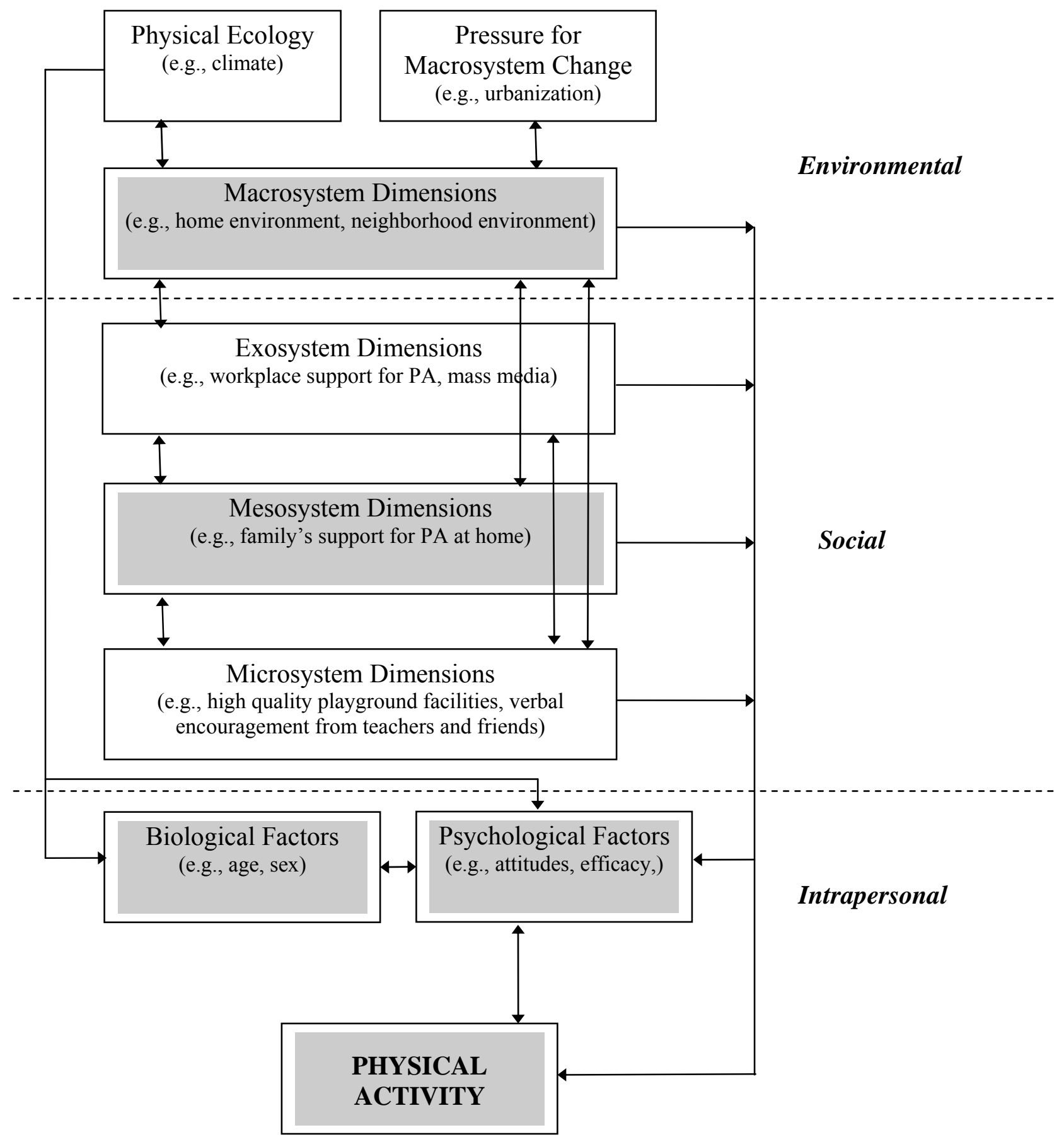

Figure 2-1. The Ecological Model of Physical Activity (EMPA) ${ }^{62}$

(Domains that were measured in this study are shaded.) 
The remainder of this review, which focuses on determinants of physical activity and obesity, is organized into three parts : individual factors, social environment and physical environment factors.

\subsubsection{Individual Factors}

\subsubsection{Sex and Age}

Epidemiological studies on youth physical activity have consistently revealed that males are more active than females, ${ }^{64-67}$ and that age is inversely associated with physical activity. ${ }^{64,65,67,68}$ The declines throughout youth have been reported in both self-report and objective measure of physical activity. ${ }^{64}$ The studies reported that the annual rate of decline is much greater during adolescence than during adulthood. ${ }^{66,69}$ Through the summary across studies, the age of greatest decline in physical activity levels were 13-18 years of age in both boys and girls, ${ }^{66,69-71}$ however, the declines were different between sexs. The decline in physical activity levels in boys was greater than girls. ${ }^{69,70,72}$ Although boys are decreasing most in physical activity, boys are more active than girls during the teen years. ${ }^{65-67}$

\subsubsection{Maturation}

Studies of physical activity have shown that physical activity declines with age, particularly the decline is greatest during the adolescent years in both boys and girls. ${ }^{67,73}$ Studies have shown consistent findings that boys are more active than girls at all ages. ${ }^{64}$, ${ }^{65,67,74-78}$ Other studies have reported that the lower level of physical activity reported in girls when compared with boys was attributed to the maturational difference between boys and girls of the same chronological age. ${ }^{67,78,79}$. The findings of Thompson et al ${ }^{78}$ 
and Sherar et al. ${ }^{67}$ demonstrated that the sex differences in physical activity were no longer apparent when aligned on a biological age. On average, girls mature approximately 2 year earlier than boys. ${ }^{67,78,79}$ For example, on average, girls reach peak height velocity (PHV) — a somatic indicator of physical maturity—at approximately 12 year of age, whereas boys, on average, reach the same maturity milestone at approximately 14 year of age.

PHV is an indicator of somatic maturity and reflects the age at maximum growth rate in stature during adolescence. ${ }^{67}$ The Saskatchewan Childhood Growth and Development (SCGD) research group has developed sex specific multiple-regression equation that predict how far an individual is from this maturational milestone (year from age at PHV). ${ }^{80}$ The prediction of how far an individual is from their Age of Peak Height Velocity (APHV) is based on the differential growth and timing of leg length and sitting height. To predict the years from APHV the following variables are required: sex, date of birth, date of measurement, height, sitting height and weight. Accuracy of the measurements is of vital importance, as any errors especially in sitting height will dramatically alter the precision of the prediction. ${ }^{81}$

\subsubsection{Attitudes/beliefs}

The attitudes and beliefs of individuals — as described in the Heath Belief Model (HBM) — are psychological models that explain and predict health behaviors. ${ }^{82}$ This includes perceived benefits (one's belief in the efficacy of the advised action to reduce risk or seriousness of impact), perceived barriers (one's opinion of the tangible and psychological costs of the advised action) and perceived self-efficacy (confidence in 
one's ability to achieve a certain behavior in particular circumstances). ${ }^{83}$ According to the HBM, if people's perceived benefits of participation in physical activity outweigh the costs, they are more likely to become active and maintain activity. They also are more likely to remain active if they engage in activities that they feel confident in and feel enjoyable doing. ${ }^{38}$

Ferguson et al. indicated that adolescents who had positive attitudes about physical activity were more likely to plan and maintain physical activity in the future. ${ }^{84}$ The result of Ferguson's study also suggested that promoting positive attitudes toward physical education could influence motivation to participate in physical activity, especially among students who are not active very much. ${ }^{84}$ Research has found that the most common reason for adolescents participating in physical activity is enjoyment. ${ }^{85}$ Self-esteem also showed positive and significant correlations with physical activity behavior. ${ }^{84}$ The perceived benefits of exercise, self-esteem, attitudes about physical education and belief in one's ability to maintain commitments to physical activity have positive relationship with exercise intent. ${ }^{84}$

\subsubsection{Genetics}

Genes, which is the DNA that children inherit from their parents, is a biologic determinant of the susceptibility of children to suffer from overweight and obesity. Some evidence demonstrate that genetic factor may play an important role in high levels of BMI. ${ }^{86}$ It is estimated that genetics contribute from $20 \%$ to $75 \%$ of variability in body weight and composition within a population. ${ }^{87}$ Because of genes, some people burn 
calories faster or slower than others. ${ }^{88}$ It is noted that obesity would not be possible if humans did not have the genes for it. ${ }^{22}$

However, the prevalence of childhood obesity has dramatically increased over the past several decades, while the genetic composition of the population did not change quickly. ${ }^{11}$ It seems unlikely that the increased global prevalence of obesity has been driven by a dramatic change in human genetics. Therefore, the large increase in the prevalence of obesity must reflect major changes of non-genetic factors.

\subsubsection{Dietary Intake}

Obesity is not only the result of low levels of physical activity but also arises from a long-term energy imbalance in which energy intake exceeds energy expenditure. ${ }^{89}$ Obesity has been associated with consumption of a greater proportion of dietary fat. With the development of the food industry, the availability of fast foods with high fat, salt and sugar contents, (i.e. soda instead of juice, water or milk as beverage of choice everywhere (at school, and public areas)) have created more chance for people, and especially for children, to gain weight.

The most striking behavioral changes that have occurred have been an increased reliance on high-fat and energy-dense fast foods, with larger portion sizes, combined with an ever-increasing sedentary lifestyle. ${ }^{90}$ Currently, it is hard for children to stay lean when portions keep growing.

Furthermore, various social and environmental factors are thought to contribute to the development of dietary habits among children, including television viewing, game playing, and the availability of high-fat and high-sugar foods. The marketing of food and 
beverages on television frequently targets teens and focuses on products with high sugar contents and saturated fats. ${ }^{91}$ These factors have indirectly affected children's eating habits with the obvious consequence of a significant increase in the consumption of unhealthy fast foods and beverages (e.g. hamburger, snack, and soda) rather than other healthy meals (e.g. fruit, vegetable, milk or water).

In addition, there is evidence showing a relationship between eating while watching TV and weight gain. ${ }^{92}$ Evidence showed that TV viewing is inversely proportional with ingestion of fruits and vegetables among adolescents. These associations may be a result of the replacement of fruits and vegetables in youths' diets by foods highly advertised on television. ${ }^{93} \mathrm{TV}$ viewing encourages unhealthy eating and activity behaviors by creating opportunities for teens to sit idle while consuming their favorite snack for several hours each day. ${ }^{91}$

\subsubsection{Socio-demographic Background}

Socioeconomic status (SES) is a broad concept, including economic status (e.g. income), social status (e.g. measured by education) and work status (e.g. assessed by occupation) ${ }^{94}$ Socio-economic status is related to a variety of health outcome in Canadian childhood. ${ }^{95}$ Studies have indicated that a low SES is associated with lower levels of physical activity, ${ }^{96}$ and is a risk factor for obesity. ${ }^{59,97}$

Physical inactivity is much influenced by socio-demographic factors. Higher socioeconomic status measured by parental education and family income has a substantial impact on likelihood of engaging in inactivity. Some studies have reported that the prevalence of unhealthy behaviors including inactive lifestyle is higher among poorer 
population areas (i.e., lower concentration of university-educated persons, or lower average family income). ${ }^{98-100}$ According to Canadian Fitness and Lifestyle Research Institute, most sedentary Canadians have a secondary education or less. ${ }^{101}$ The National Population Health Survey (NPHS) 1998-1999 showed that about 62\% of persons without a high school education are inactive whereas $49 \%$ of persons with post-secondary education are inactive. ${ }^{102}$ About $62 \%$ of persons with a household income of $\$ 20,000$ or less are inactive versus $44 \%$ of persons with a household income equal to or greater than $\$ 80,000$ are inactive. ${ }^{102}$

Besides, people living on a low income are faced with poor living conditions, consequently they have less chance to access recreational facilities as well as physical activity settings. ${ }^{97,}{ }^{103}$ Studies show that low SES neighborhoods have less healthy social and physical environments, leading people have less opportunity to participate in physical activity to maintain a healthy bodyweight. ${ }^{104}$ Another study determined that neighborhoods with lower safety and greater social disorder were associated with less physical activity among children age from 11-16 year olds. ${ }^{105}$

Although the prevalence of inactivity has decreased significantly since $1981^{106}$ it is the case that the social disparities associated with physical inactivity have not decreased. The prevalence of inactivity has decreased only slightly in socio-economically disadvantaged groups but it has decreased dramatically among groups with higher income and education. ${ }^{102}$

Studies indicated that the rate of overweight and obese children decreased when the family income increased, ${ }^{107}$ and the development of overweight and obesity is more 
likely to occur in the lower-income group than the higher-income counterpart. ${ }^{108}$ The 1998-1999 NLSCY found that among children aged 2 to 11, those who lived in families with incomes below the low-income cut-off (LICO) were more likely to be obese (25\%) than those living in families with incomes above the LICO $(16 \%) .{ }^{107}$

In Canadian adults, there is an converse relationship between level of education and prevalence of overweight, ${ }^{59}$ and this will indirectly affect to the likelihood of their children being overweight and obesity. Findings from a research study from the Canadian National Longitudinal Survey of Children and Youth (NLSCY) indicated that the risk of childhood overweight is low in higher SES families and higher educated parents. ${ }^{59}$

Recently, higher SES groups have been recognized to have a tendency toward healthier diets than lower SES groups. ${ }^{94}$ Studies determined that there is an association between obesity development and low SES neighborhoods. Poorer neighborhoods tend to have a high concentration of fast-food restaurants ${ }^{97}$, therefore these neighborhoods promote the consumption of energy dense foods and also discourage physical activity participation. ${ }^{97}$ People in low SES also have less probability to afford healthy foods (e.g., diet foods) that would help them maintain a normal body weight. ${ }^{97}$

As a result, children in lower SES groups are more likely to choose unhealthy and inappropriate foods, less likely to access recreation facilities, less likely to be involved in physical activities, and therefore they are more likely to become obese.

\subsubsection{Sedentary Behaviors and Physical Inactivity}

In contrast to physical activity, inactivity is defined as the amount of time spent in sedentary behavior and when body movement is minimal. ${ }^{109}$ Physical inactivity 
contributes to deterioration in body composition by decreasing the amount of metabolically active tissues. The metabolic rate decreases significantly with a sedentary lifestyle, making less active individuals more likely to gain unhealthy weight, as a result significant reductions in total energy expenditure play a key role in the development of obesity. ${ }^{91}$ The common types of sedentary activities include watching television, playing video game, reading, surfing the Internet, and using computer. ${ }^{110-112}$

Physical inactivity has been considered as a significant public health problem not only in Canada but also in many other industrial countries. ${ }^{113,114}$ There is a number of studies confirmed that the increase in spending time in sedentary behaviors may result in decrease energy expenditure, increased risk of chronic disease (i.e. heart disease, diabetes, and hypertension) that lower the quality of life. ${ }^{114,115}$ Especially, physical inactivity has been identified as an important changeable risk factor for obesity. ${ }^{116}$

Studies have revealed that physical activity is a protective effect against obesity. ${ }^{87}$ Evidence from the Canadian epidemiological studies shows that physical activity among children aged 7 to 11 is negatively associated with overweight and obesity, while TV viewing and video game use is a risk factor contributed to increase body weight. ${ }^{117}$ Obese children tend to be more likely to be inactive than non-obese children. In 1998-1999 NLSCY, the overall inactivity levels among obese children was 38\% compared with 30\% among non-obese children. ${ }^{60}$

According to a survey carried out in $1997,62 \%$ of Canadians are physically inactive. ${ }^{38}$ Estimates from the 1998-1999 National Population Health Survey (NPHS) indicate that the majority of Canadian are insufficiently active for health benefits, about 
$55 \%$ of Canadians are inactive. ${ }^{102}$ The Physical Activity Monitor (PAM) performed in 2001 by the Canadian Fitness and Lifestyle Research Institute shows that $57 \%$ of Canadians are either inactive or moderately active. ${ }^{102}$

Among children, the 2000-2001 Canadian Community Health Survey (CCHS)—a survey basing on self- or parental-reported levels of physical activity—revealed that $27.7 \%$ of Canadian youth aged 12 to 19 are physically inactive, and only $38.4 \%$ are physically active. ${ }^{22}$ In 2003 , Canadian children age 2 to 11 spent an average of 14 hours per week watching television, while Saskatchewan children of the same age spent an average of 14.6 hours per week watching television. ${ }^{118}$ Over $80 \%$ of Canadian households with children under 18 had access to the Internet in the same year. ${ }^{119}$

\subsubsection{Social Environment Factors}

\subsubsection{Family's influence}

Family is the major source of influence that affects the behavior and lifestyle of children. Involvement of the family led to better development in health behaviors in nutrition and physical activity in children. Parental habits, such as physical activity, and eating habits, are associated with those of their children. Since parents often prepare family meals, their children are more likely to have eating habits as their parents. ${ }^{120}$ If the parents consume fruits and vegetables less frequently than fast foods, or prefer sedentary activities over physically active entertainment, their children are more likely to mirror these behaviors. In contrast, children of parents with good nutritional knowledge are more likely to eat healthy meals. The eating behaviors of people around children will 
influence the children's regime, therefore contributing to an increase or decrease in the probability of becoming obese.

Parental overweight and obesity is the most important risk factor for obesity in children. ${ }^{24-26}$ Children who have two obese parents are at the highest risk of becoming obese due to the inheritance of obesity genes from their parents. ${ }^{121}$ Among children who live with an obese parent, $10 \%$ of girls were obese and $12 \%$ of boys were obese. ${ }^{122}$ Whitaker et $\mathrm{al}^{123}$ have also reported that a twofold to threefold increase in childhood obesity at all age when parents are obese. Similarly Locard and colleagues ${ }^{124}$ have reported that both parental overweight increased the risk of childhood obesity by threefold. There seem to be a strong correlation between the health behaviors of parents and those of their children.

In addition, children of obese parents also demonstrate decreased physical activity. ${ }^{125,}{ }^{126}$ In the families with both active parents, the children were more likely to be active than children of two inactive parents. This influence of parents' physical activity levels on children's activity levels can be explained that the active parents serve as role models, enhance and support their child to participate in physical activity, and transmit genetic factors that predispose the child to increase levels of physical activity. ${ }^{127}$ Some studies found that activity levels were highest in children with two active parents, slightly lower in children with one active parent, and lowest in children with no active parent. ${ }^{127-}$ 130 


\subsubsection{Support from Parents and Peers}

Social support is considered one of the most well-established determinants in supporting physical activity. ${ }^{131}$ Both parents and peers play a critical role in creating an important cue for physical activity in youth. ${ }^{23,68,132-134}$ Parents serve as the most important behavioral role models from early childhood to teen age of children, while the role of peers influence is supposed to increase with age. ${ }^{135}$ Peers exert their influence on adolescent behavior through imitation and social reinforcement. ${ }^{136}$

The Social support for physical activity include instrumental and direct support (e.g., provide transportation to physical activity settings, pay for equipment or the physical activity program, participate in physical activity with children); motivational support (e.g., encourage children to stick with physical activity); and observational support (e.g., watch children participate in physical sports, model physical activity to children). ${ }^{137}$

Findings from a study on youth sport participation indicated that both peers and parents have important influences on sport selection. ${ }^{138}$ Another study on parent-youth association indicated that parent have been shown to have strong influences on physical activity. ${ }^{139,140}$ Parental encouragement of activity is positively associated with physical activity among youth. ${ }^{139,140}$ More active parents have been shown to have more active children. ${ }^{126,140,141}$ Being role models-parents who are physically active-will help children to establish positive behaviors for physical activity and provide support in remaining active. ${ }^{142}$ The study of Tergerson et al. has found that 'having a friend to exercise with' was the most helpful motivation to participating in physical activity for 
both males and females. ${ }^{143}$ This study also found that the encouragement from friends has stronger influence on females than males. ${ }^{143}$

\subsubsection{Physical Environment Factors}

According to the World Health Organization (WHO), "the fundamental causes of the obesity epidemic are societal, resulting from an environment that promote sedentary lifestyles and the consumption of high-fat, energy-dense diets" ${ }^{20}$ There is general agreement that the obesity epidemic is largely associated with an environment that promotes excessive food intake and discourages physical activity. ${ }^{22}$ The physical environment has also been defined as a modifiable factor that directly influences the opportunity to engage in physical activity ${ }^{96}$ The most common environmental factors that impact on physical inactivity are related to facilities and safety. These environmental areas include the home, the school, the public place, the neighborhood and transportation.

In current society, the modern environment is one in which technological advances have created many opportunities for sedentary lifestyle and many reasons for reducing physical activity on a daily basis. This has lead to an increased trend towards overweight and obesity.

Some studies support the ecological hypothesis that there is a relationship between environmental variables and physical activity. ${ }^{125,144}$ Modern life constantly encourages people to sit down and seek a comfortable life that avoids all physical effort. The more sedentary lifestyle is also caused by an increased reliance on technology and labor-saving devices. Examples of energy-saving devices that have resulted in a steady decline in physical activity include: increased use of automated transport just to travel a 
few hundred meters rather than walking or biking; use of automated equipment (such as washing machines) in the household; increased use of television and computers for entertainment and leisure activities; and using elevators to go up - or even down instead of stairs..$^{90}$

\subsubsection{Home Environment}

The home environment is a critical factor in the development of childhood obesity. ${ }^{145}$ Children today are engaging more and more in sedentary activities requiring little energy expenditure for entertainment (such as TV, videogames, DVD, and computers) than active leisure activities (e.g. playing outsides or riding bicycle). ${ }^{58,91} \mathrm{~A}$ number of studies found that TV viewing and playing computer games for longer periods of time, or not participating in sports outside have been shown as major contributors to the development of obesity in children and adolescents. ${ }^{13,21,24,91,146}$ Findings from study of Dietz et al. suggested that the prevalence of obesity increase by approximately $2 \%$ for each additional hour of television viewing per day. ${ }^{147}$

\subsubsection{Neighborhood}

Besides the impact of modern technologies on the reduction of physical activity in children, the neighborhood is also an independent contributor to children's sedentary lifestyle. The characteristics of the neighborhood where people live are important elements that affect residents' daily activities. Neighborhoods—where unsafe or unavailable of physical activity settings - contribute to the lack of motivation for increasing physical activity are considered one of the risk of development of overweight and obesity in children. Safety issues in the community are a very important factor that 
effects the residents' participation in physical activity. For instance, concerns about neighborhood safety may be a barrier to physical activity. ${ }^{22,34}$ Neighborhoods that lack safe areas for physical activity such as free of crime and traffic may hinder children from outdoor playing and contribute to increasing physical inactivity. The threat of crime or unsafe traffic problems makes people afraid to go outside and discourage them from being active. Parents in those areas frequently state their reluctance to allow their children to play outside for fear of exposure to violence, crime, and illicit drug use and therefore they often keep their children indoors rather than let them play outside. ${ }^{148}$ This limits the amount of physical activity among these children, and consequently increases the likelihood that they will spend their time sitting in front of the TV and snacking. ${ }^{149}$ Thus, parents are more likely to prefer having their children watch television at home rather than play outside because they are then able to keep an eye on their children while doing their chores. ${ }^{150}$ As a result children who live in dangerous neighborhoods are more likely to be involved in sedentary and more likely to be obese than those who live in safer environments. The study of Molnar et al. determined that neighborhoods with lower safety and greater social disorder were associated with less physical activity among children age from 11-16 year olds. ${ }^{105}$

There is evidence showing a correlation between the built environment and human behavior, particularly physical activity. The built environment embraces urban design, land use, and the transportation system, and includes patterns of human activity within the physical environment. ${ }^{151}$ Poorly built environments-those that do not contain adequate schools or shops (which can be reached by walking), or that lack safe playing grounds/parks, or adequate bike trails or pedestrian walkways ${ }^{90,91}$-do not motivate active 
living among residents and especially among children in those areas. These characteristics will create opportunities for children not to be physically active and rely more heavily on the use of vehicles to go to schools or shops, and spending more time on passive recreation in leisure time instead of engaging in outside activities.

\subsubsection{Schools}

Besides home and neighborhood, school—where most children spent most of their daytime to attend - is a logical environment for establishing and promoting children physical activity and eating behaviors. Since children eat at least one meal per day in school, the school cafeteria may have influence to eating patterns in children. ${ }^{152}$ the consumption of high-fat foods among children is strongly correlated with the availability of these items in school environment. In many schools, food and beverage vending machines with high-fat and high-sugar ingredients are common. ${ }^{22}$ Children in schools are now faced with a massive range of high-fat and high-calories foods, while lacking guideline on choosing healthy foods. ${ }^{22}$ Therefore the food service that provides low proportion of high energy density foods, fruits and vegetables in school can help children to learn healthful eating behaviors and influence the eating habits of children.

In school, children are also provided necessary facilities, such as gyms, physical activity equipment, outdoor playing fields, and physical education programs. In Canada, however, physical education becomes optional. While in Quebec physical education is required in school curriculum until graduation, in all other provinces physical education is becoming an option as early as Grade $8 .{ }^{153}$ 


\subsection{Summary}

In summary, this review of the literature showed that there are a variety of factors that affect physical activity and overweight/obesity in children. These are categorized into three main domains: intrapersonal factors, social environment factors and physical environment factors.

Among intrapersonal factors, age — an important biological factor-has had inverse association with physical activity. ${ }^{64,65,67,68}$ Other studies showed that the decline in physical activity levels in boys was greater than girls; ${ }^{69,70,72}$ however other studies have shown that boys are always more active than girls during the teen ages. ${ }^{65-67}$ Some studies have demonstrated that when biological age was aligned between girls and boys, there were no differences in physical activity between sexes. ${ }^{67,78}$ On average, girls mature approximately 2 year earlier than boys. ${ }^{67,78,79}$ Another biological factor is genes - the DNA that children inherit from their parent — which has been demonstrated that it plays an important role in high levels of BMI. ${ }^{86}$ Studies have also indicated that adolescents who had positive beliefs and attitudes about physical activity were more likely to maintain physical activity in future. ${ }^{84}$ Studies have also indicated that a low SES status is associated with lower levels of physical activity, ${ }^{96}$ and is a risk factor for obesity. $^{59,97}$

Adolescent behaviors and lifestyles (such as dietary intake, sedentary behaviors) are also important factors among intrapersonal domain. Obesity is not only the result of low levels of physical activity but also arises from a long-term energy imbalance in which energy intake exceeds energy expenditure. ${ }^{89}$ Physical inactivity has been identified 
as an important changeable risk factor for obesity. ${ }^{116}$ In 2003, Canadian children age 2 to 11 spent an average of 14 hours per week watching television, while Saskatchewan children of the same age spent an average of 14.6 hours per week watching television. ${ }^{118}$

Family and friends are important factors in social environment domain. Family is the major source of influence that affects the behavior and lifestyle of children. Involvement of the family in children's lives play an important role in developing health behaviors in nutrition and physical activity in children. Besides that, social support from family and peers are considered one of the most well-established determinants in supporting physical activity. ${ }^{131}$

Home, neighborhood and schools are the main factors among physical environment domain. A study indicated that home environment is a critical factor in the development of childhood obesity. ${ }^{145}$ At home, children today are engaging in more and more in sedentary activities with little energy expenditure, such as playing video games and computers than being active and playing outside. ${ }^{58,91}$ The neighborhood where children live is also an independent contributor to children's sedentary lifestyle. The characteristics of the neighborhood where people live are important elements that affect residents' daily activities. The study of Molnar et al. determined that neighborhoods with lower safety and greater social disorder were associated with less physical activity among children age from 11-16 year olds. ${ }^{105}$ Furthermore, schools - where most children spent most of their daytime - is a natural environment for establishing and promoting children's physical activity and healthy eating behaviors. 
In this study the main objective is to examine the relationship between physical activity and adolescent's overweight/obesity, intrapersonal factors, social and physical environment factors. 


\section{METHODOLOGY}

\subsection{Study Design}

The data for answering the research questions for this study was obtained from Saskatoon in motion research, an initiative funded by Canadian Institutes of Health Research Community Alliances for Health Research (CAHR) program. Specifically, data were obtained from a five-month long longitudinal study of in motion research. The intent of the longitudinal study was to draw a sample that is representative of all youth in Saskatoon between the ages 12 to 18 years, specifically across the socioeconomic spectrum. The sample was recruited from two participating high schools and five elementary schools from two socio-economically diverse geographic areas in Saskatoon (low and high socioeconomic status). The Saskatoon Public School Division facilitated the recruitment of student participants into the study.

Study protocols were approved by the University of Saskatchewan Behavioral Research Ethics Board in 2002. All students enrolled in the selected classes were invited to participate. A written informed consent was obtained from the parents and guardians to indicate their willingness to have their children participate in the study. The study also obtained permission from the Executive Director of the School Boards (Public and Catholic), as well as the Principal and classroom teachers of each participating school.

Questionnaires were administered by trained research personnel during a class period to those students who had returned a written informed consent completed by students and their parents or guardians. From February to June 2003, the survey was distributed through the schools to students. 


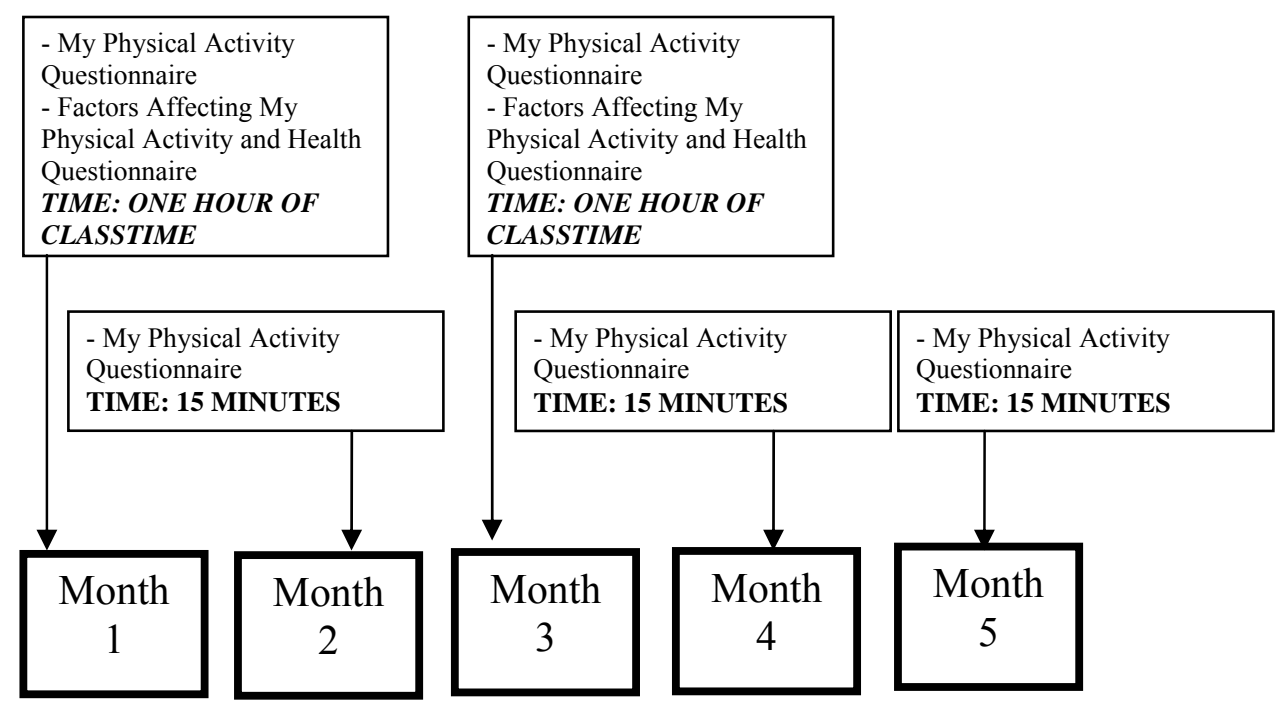

Figure 3-1. Description of the Study Design

\subsection{Sample Size}

In total, 835 adolescents from grade 7 to grade 12 were enrolled into the study. The adolescents were recruited from seven schools in Saskatoon: Bedford Road Collegiate: 325; Evan Hardy Collegiate: 244; St. Egnatoff School: 148; King George School: 35; Caswell Hill School: 39; Westmount School: 15 and Mayfair School: 29.

Among adolescents who participated in 'My Physical Activity Questionnaire', 480 students completed 5 rounds of data collection, 552 students completed round 1 to 4 , 620 students participated in round 1 to round 3 , and 683 students completed the first two rounds. 


\subsection{Questionnaire}

\subsubsection{Physical Activity Questionnaire}

Physical activity levels were assessed using the 'My Physical Activity' Questionnaire (Modifiable Activity Questionnaire for Adolescents ${ }^{154}$ - MAQ-A) (Appendix B). The MAQ-A is a self-report measure of physical activity designed for use with youth and adolescents. In previous studies, this instrument has been demonstrated to be a reliable and valid measure of self-report physical activity in youth and adolescents. ${ }^{154,155}$ The MAQ-A questionnaire used in this study asks participants to report physical activity that they had engaged in over the last four weeks. The original version required participants to report their physical activities over the past 12 months.

The questionnaire was administered to all students once per month for a total of five consecutive months from February to June 2003. Data were collected on the frequency, duration, type, location and intensity of the individual's physical activity done over this period. The level of overall physical activity was measured by asking respondents questions about 'How often' and 'How many hours' each week they participated in sports or other physical activities.

\subsubsection{Physical Activity Determinants Questionnaire}

To assess physical activity determinants, the 'Factors Affecting My Physical Activity’ questionnaire (Appendix C) was used. This questionnaire was administered in month one and three (February and April 2003) to all participating students. Students were asked to report on a comprehensive array of questions on the intrapersonal, social, 
environmental, and health determinants of physical activity. Height and weight of adolescents were also collected through self-report.

The questionnaire was composed of six parts: Part A included questions about the child's perception on physical activity; Part B had questions about the child's expectation about the benefit of physical activity; Part $\mathbf{C}$ included questions about factors contributing to inactive lifestyle or about barriers to physical activity; Part D included questions about students' perceptions of level of participation in physical activity of their family and friends; Part E focused on the child's environment; Part F included general questions about the child's health and family circumstances.

\subsection{Ethics Approval and Confidentiality}

Ethics approval for this data analysis was obtained from the University of Saskatchewan Behavioral Research Ethics Board in December 2002 (BEH \# 688). All information was to be kept confidential and used only for research purposes. All personal identifiers, kept under lock and key of the principal investigator, were not available to the author. Data will be kept by the principal investigator for a minimum of five years after the study has been completed. A copied of the certificate of approval is found in Appendix D. 


\subsection{Analytic Strategy}

\subsubsection{Measures and Definitions}

\subsubsection{Outcome Variables}

Physical activity: To assess physical activity levels, the Modified Activity Questionnaire for Adolescents ${ }^{154}$ (MAQ-A) was used. This measure provides an indication of participants' total daily energy expenditure. Level of energy expenditure resulting from time spent in physical activity was calculated and reported as kilocalories per kilogram of body weight per day (KKD). For each activity listed by participants, the product of metabolic cost (METS), average duration in minutes, and number of times participated in physical activity during the month was calculated, and then divided by the number of days (28 days) in four weeks, and then divided by $60(1 \mathrm{KKD}=60$ METS $\min /$ day). The value of each activity listed was summed to yield a total KKD value for each participant. This continuous variable was then used to create three categories of physical activity: Low (defined as energy expenditure equivalent to less than $2 \mathrm{KKD}$ ), Moderate (2-8 KKD), or High activity levels (greater than $8 \mathrm{KKD}$ ). These categories reflect the suggested levels of activity that are sufficient to achieve minimal, moderate and maximal health benefits among adolescents. ${ }^{156}$ Youth or adolescents having a KKD value greater than 8 is considered to enough physical activity to achieve health benefits, while those having a value less than $2 \mathrm{KKD}$ is considered sedentary. 


\subsubsection{Independent Variables}

Table 3-1. Description of Predictor Variables

\begin{tabular}{|c|c|c|}
\hline Name of variable & $\begin{array}{l}\text { No. of } \\
\text { items }\end{array}$ & Description \\
\hline \multicolumn{3}{|l|}{ Individual factors } \\
\hline Sex & 1 & Two values, ' 1 ' for "female" and '2' for "male". \\
\hline Age & 1 & $\begin{array}{l}\text { Age of the adolescent is a count variable which } \\
\text { ranged from } 12 \text { years to } 18 \text { years. }\end{array}$ \\
\hline Height & 1 & in centimeters \\
\hline Weight & 1 & in kilograms \\
\hline Body max index & 1 & $\begin{array}{l}\text { Body max index is calculated as the weight in } \\
\text { kilograms divided by the square of the height in } \\
\text { meters }\left(\mathrm{kg} / \mathrm{m}^{2}\right) \text {. It is often used as an indicator of } \\
\text { overweight or obesity in population based research. }\end{array}$ \\
\hline Overweight/Obesity status & 1 & $\begin{array}{l}\text { Using BMI and a classification developed by Cole } \\
\text { et al. } .^{54} \text { a new variable indicating overweight or } \\
\text { obesity status was derived. Each participant was } \\
\text { grouped into one of the following three categories: } \\
\text { ' } 1 \text { ' for children with "Healthy weight", '2' for } \\
\text { "Overweight", and '3' for "Obese". }\end{array}$ \\
\hline Weight perception & 1 & $\begin{array}{l}\text { This categorical variable measured children's } \\
\text { weight perception: ' } 1 \text { ' if perceived as being } \\
\text { "overweight" (by about } 5 \text { pounds or more), ' } 2 \text { ' if } \\
\text { perceived as "underweight" (by about } 5 \text { pounds or } \\
\text { more), or " } 3 \text { " if perceived "weight is okay". }\end{array}$ \\
\hline
\end{tabular}




\begin{tabular}{|c|c|c|}
\hline Name of variable & $\begin{array}{l}\text { No. of } \\
\text { items }\end{array}$ & Description \\
\hline Self-efficacy & 6 & $\begin{array}{l}\text { Six items measured how confident children are } \\
\text { regarding scheduling time for physical activity, and } \\
\text { how they believe that they can be active even if } \\
\text { they feel tired, or in bad mood, or don't have the } \\
\text { time. These questions used four scales to measure } \\
\text { the confident levels: '0' for "Not confident at all", } \\
\text { '3' for "Somewhat Confident", ' } 7 \text { ' for "Confident", } \\
\text { and ' } 9 \text { ' for "Very Confident". }\end{array}$ \\
\hline Self esteem & 9 & $\begin{array}{l}\text { This measure included } 9 \text { items that measured how } \\
\text { children feel about themselves and about their } \\
\text { future. These items were scored on a five-point } \\
\text { Likert scales: ' } 1 \text { ' for 'Never", ' } 2 \text { ' for 'Seldom", ' } 3 \text { ' } \\
\text { for "Sometimes", ' } 4 \text { ' for "Often", and ' } 5 \text { ' for } \\
\text { "Always". }\end{array}$ \\
\hline Self rated health & 1 & $\begin{array}{l}\text { This variable indicates the respondent's health } \\
\text { status based on their own judgment. This variable } \\
\text { was scored on a five-point Likert scale with } \\
\text { endpoints comprising "1" for "Excellent health", } \\
\text { and "5" for "Poor health". }\end{array}$ \\
\hline Neighborhood SES & 1 & $\begin{array}{l}\text { This categorical variable indicated the level of } \\
\text { socioeconomic status of the neighborhood where } \\
\text { children live: '1' indicated "High SES", '2' } \\
\text { indicated "Medium SES", and '3' "Low SES". The } \\
\text { neighborhood SES measure was obtained from the } \\
\text { analysis of individual postal codes. }\end{array}$ \\
\hline
\end{tabular}




\begin{tabular}{|c|c|c|}
\hline Name of variable & $\begin{array}{l}\text { No. of } \\
\text { items }\end{array}$ & Description \\
\hline Family's financial situation & 1 & $\begin{array}{l}\text { This variable indicated the respondents' family } \\
\text { income: '7' for "Wealthy", '6' for "Well-off", '5' } \\
\text { for "Comfortable", '4' for “Adequate", '3' for } \\
\text { "Difficult", '2' for "Poor" and '1' for "Don't } \\
\text { Know". }\end{array}$ \\
\hline Academic performance & 1 & $\begin{array}{l}\text { This variable indicated the level of self-reported } \\
\text { academic achievement accomplished by the } \\
\text { respondent. This is a categorical variable with three } \\
\text { values, '1' for "Academic achievement below } \\
\text { average", '2' for "Academic achievement at } \\
\text { average", and '3' for "Academic achievement } \\
\text { above average". }\end{array}$ \\
\hline \multicolumn{3}{|l|}{ Social environmental factors } \\
\hline Parental work & 2 & $\begin{array}{l}\text { This variable indicated if parents work full-time or } \\
\text { part-time. This variable is a categorical variable } \\
\text { with } 3 \text { values, ' } 1 \text { ' for "Working full time", ' } 2 \text { ' for } \\
\text { "Working part time", and ' } 3 \text { ' for "Other". }\end{array}$ \\
\hline Parental education & 2 & $\begin{array}{l}\text { These variables indicated the level of education } \\
\text { acquired by their parents. This variable is a } \\
\text { categorical variable with four values, ' } 1 \text { ' for } \\
\text { parental education less than high school, '2' for } \\
\text { parental education finished high school or trade } \\
\text { school, ' } 3 \text { ' for parental education finished } \\
\text { university, ' } 4 \text { ' for other. }\end{array}$ \\
\hline
\end{tabular}




\begin{tabular}{|c|c|c|}
\hline Name of variable & $\begin{array}{l}\text { No. of } \\
\text { items }\end{array}$ & Description \\
\hline Family's support & 11 & $\begin{array}{l}\text { This measure includes } 11 \text { questions which measure } \\
\text { children's perceptions on level of support from } \\
\text { their family on physical activity. These questions } \\
\text { use five-point Likert scales to measure support } \\
\text { level from adolescents' families. The endpoints of } \\
\text { these scales were } 1 \text { for "Never" and } 5 \text { for "Very } \\
\text { Often". }\end{array}$ \\
\hline Friend's support & 9 & $\begin{array}{l}\text { This variable measured } 9 \text { questions on children's } \\
\text { perceptions on the level of support from their } \\
\text { friends on physical activity. These questions use } \\
\text { five-point Likert scales to measure support level } \\
\text { from adolescents' friends with endpoints "1" for } \\
\text { "Never" and "5" for "Very Often". }\end{array}$ \\
\hline Benefits of physical activity & 17 & $\begin{array}{l}\text { This measure included } 17 \text { questions about } \\
\text { expectation of adolescents on the benefits of } \\
\text { physical activity. These questions use five-point } \\
\text { Likert scales to measure how important these } \\
\text { benefits are to adolescents when they are active. } \\
\text { The endpoints of these scales were " } 1 \text { " for "Not } \\
\text { important", and " } 5 \text { " for "Very Important". }\end{array}$ \\
\hline Barriers to physical activity & 15 & $\begin{array}{l}\text { This component includes } 15 \text { questions about } \\
\text { barriers that contribute to adolescents not being } \\
\text { active. These questions use three scales to measure } \\
\text { how important these barriers contribute to inactive } \\
\text { status in adolescents. The endpoints of these scales } \\
\text { were } 1 \text { for "Not important", and } 5 \text { for "Very } \\
\text { Important". }\end{array}$ \\
\hline
\end{tabular}




\begin{tabular}{|l|c|l|}
\hline \multicolumn{1}{|c|}{ Name of variable } & \multicolumn{1}{|c|}{$\begin{array}{c}\text { No. of } \\
\text { items }\end{array}$} & \multicolumn{1}{|c|}{ Description } \\
\hline Physical environmental factors & 1 & $\begin{array}{l}\text { This variable measured the number of items (14 } \\
\text { items in total) available at home which supports } \\
\text { physical activity in children. This is a continuous } \\
\text { variable with lowest value of '0' and highest value } \\
\text { of'14'. }\end{array}$ \\
\hline Home environment & 1 & $\begin{array}{l}\text { This variable measured the number of items (8 } \\
\text { items in total) available in the neighborhoods where } \\
\text { children live that support physical activity. This } \\
\text { variable is a continuous variable with lowest value } \\
\text { of '0' and highest value of '8'. }\end{array}$ \\
\hline Neighborhood environment & 1 & $\begin{array}{l}\text { This variable measured children's own sense of } \\
\text { safety walking in their neighborhoods. This } \\
\text { categorical variable was scored on five-point Likert } \\
\text { scales with endpoints of '1' for "Very Unsafe" and } \\
\text { '5' for 'Very Safe". }\end{array}$ \\
\hline Neighborhood safety & 1 & $\begin{array}{l}\text { This variable measures a specific aspect of safety. } \\
\text { That is, whether getting to and from the physical } \\
\text { activity or program. This variable was scored on } \\
\text { five-point Likert scales. The endpoints of this scale } \\
\text { were '1' for "Very Unsafe" and '5' for "Very } \\
\text { Safe". }\end{array}$ \\
\hline Travel safety & $\begin{array}{l}\text { This variable measured the number of physical } \\
\text { activity facilities (among 12 items in total) } \\
\text { available on a frequently traveled route or within a } \\
5 \text {-min drive from their home or school. This } \\
\text { variable is a continuous variable with the lowest } \\
\text { value of '0' and highest value of '12'. }\end{array}$ \\
\hline
\end{tabular}




\subsubsection{Methods of Analysis}

\subsubsection{Characteristics of the Study Population}

Graphical and tabular techniques were used to describe the main characteristics of this study population. The overview of the characteristics for this study includes proportion of physical activity level, BMI, neighborhood socio-economic status, financial situation, age and sex of adolescents.

\subsubsection{Data Management}

Data collected through five time points from My Physical Activity Questionnaire were merged to create a longitudinal data file for the analysis—called dataset 1.

Although the data collected from the "Factors Affecting My Physical Activity" questionnaire was available for Time One (February 2003) and Time Three (April 2003) only, they were also used to create a longitudinal file with five time points - called dataset 2 - that correspondents with the five time points of physical activity questionnaire. The data collected from Month One (February 2003) was also used as the data for Month Two (March 2003), and the data collected from Month Three (April 2003) was also used as the data for Month Four and Five (May and June 2003).

Then these two data sets (dataset 1 and dataset 2) were merged to create a five time point longitudinal data including both data colleted from the "My Physical Activity" and "Factors Affecting My Physical Activity" questionnaires. This final data were used to conduct all statistical analyses in this study.

To keep consistent timelines in the following parts of this thesis, time points to collect physical activity data are called Time 1, Time 2, Time 3, Time 4 and Time 5 
correspond with month One to month Five (February to June 2003). To fit with the timelines in collecting physical activity data, time points to collect data of physical activity determinants are called Time 1 and Time 3 respectively with month One and Three (February and April 2003).

All subjects' information which was not identified or missed was coded as missing in the data set for further analysis.

\subsubsection{Statistical Analysis}

\section{- Factor Analysis:}

In this study, the "Factors Affecting My Physical Activity" questionnaires included the large number of ordinal-scaled items in each domain. The factor analyses were applied to reduce large sets of data into smaller subsets of measurement variables. Then the factor scores of subsets provide individual's scores on these subsets of measures.

A principal components analysis with orthogonal and oblique rotations was used to determine whether the domains of self-efficacy, perceived benefits of physical activity, perceived barriers to physical activity, family's supports, friend's supports and selfesteem could be categorized into meaningful subsets. The criteria for acceptable factors in each analysis were to extract only those factors whose eigenvalues exceeded 1. All factor loadings were reported. The criteria for inclusion of an item on any given subscale were 0.40 or higher. To determine the reliability of the scales, internal consistency was calculated for each of the resulting factors using Cronbach's alpha coefficient. 


\section{- Bivariate and Multivariate Analysis}

The analytical portion of this study proceeded in two steps. First, descriptive and correlational analyses were done to generate information about the study participants and distribution of some basic information such as physical activity. Following this descriptive step multivariable analysis was conducted to understand associations between physical activity and predictor variables. To address the research questions, we build a multivariable model which included the sets of variables that were significantly related to the dependent variable, while demonstrating a 'good fit' to the data.

All of the independent variables were first tested for a relationship with the dependent variable. All significant independent variables (including biological variables such as age, and sex) at the bivariate analysis stage were included in subsequent multivariate models. All variables that were not statistically significant in the multivariate analysis were excluded, creating a main-effects model that included only the variables that were significantly related to the dependent variable.

I used Generalized Estimating Equations (GEE) logistic regression technique to build a model for physical activity level (1= Low physical activity; $2=$ Moderate physical activity; $3=$ High physical activity).

Given that the study involved a longitudinal design (i.e., repeated measures of physical activity for the same subject over 5 time points) and an 'unbalanced' data set (i.e., there are missing data), classic statistical techniques such as repeated measures analysis of variance is not appropriate. The GEE approach is a method designed specifically to fit mathematical models to data involving repeated measurements on the 
same subject or cluster. ${ }^{157,158}$ This method allows the user to account for intra-subject correlations, which in some other standard technique are treated as nuisance parameters, or in other words repeated measurements on the same subject. Different subjects can have different numbers of repeated measurements. This method estimates model parameters by iteratively solving a system of equations based on quasi-likelihood distributional assumptions.

\subsubsection{Software}

All data analyses for this study were performed using SPSS version 15. Alpha was set as $\mathrm{p}<0.05$. The initial sorting of data and transformation of some variables was performed using SPSS version 15, and Microsoft Excel for windows. 


\section{RESULTS}

\subsection{Characteristics of the Study Population}

The main characteristics of the study population are shown in Table 4-1.

Participants ranged from 12 to 18 years and comprised roughly equal proportions of males $(48.2 \%, \mathrm{n}=406)$ and females $(50.9 \%, \mathrm{n}=429)$. The sample had a mean age (at next birthday) of 15.5 years $(\mathrm{SD}=1.58)$, and included participants drawn from six different school grade levels $\left(\mathrm{n}_{\text {grade } 7}=146(17.3 \%), \mathrm{n}_{\text {grade8 }}=120(14.2 \%), \mathrm{n}_{\text {grade9 }}=191(22.7 \%)\right.$, $\left.\mathrm{n}_{\text {grade } 10}=170(20.2 \%), \mathrm{n}_{\text {grade } 11}=105(12.5 \%), \mathrm{n}_{\text {grade } 12}=103(12.2 \%)\right)$

When classified into three neighborhood types, $26.6 \%$ of adolescents lived in low SES neighborhoods, $20.8 \%$ in middle SES neighborhoods, and 39.3\% in high SES neighborhoods; $13.4 \%$ could not be classified into a specific neighborhood type.

Table 4-1. Demographic Characteristics of the Study Population

\begin{tabular}{|l|l|c|c|r|r|}
\hline \multicolumn{2}{|c|}{ Variable } & Mean & SD & \multicolumn{1}{c|}{ n } & \multicolumn{1}{c|}{ \% } \\
\hline Sex & Males & - & - & 406 & 48.2 \\
& Females & - & - & 429 & 50.9 \\
& Missing & - & - & 8 & 0.9 \\
\hline Age at next birthday & & 15.46 & 1.58 & 834 & - \\
\hline Age (years) & 12 & - & - & 6 & 0.7 \\
& 13 & - & - & 105 & 12.5 \\
& 14 & - & - & 141 & 16.7 \\
& 15 & - & - & 173 & 20.5 \\
& 16 & - & - & 166 & 19.7 \\
& 17 & - & - & 143 & 17 \\
& 18 & - & - & 100 & 11.9 \\
& Missing & - & - & 9 & 1.1 \\
\hline
\end{tabular}




\begin{tabular}{|c|c|c|c|c|c|}
\hline \multicolumn{2}{|c|}{ Variable } & Mean & SD & $\mathbf{n}$ & $\%$ \\
\hline \multirow[t]{8}{*}{ School Grade } & 7 & - & - & 146 & 17.3 \\
\hline & 8 & - & - & 120 & 14.2 \\
\hline & 9 & - & - & 191 & 22.7 \\
\hline & 10 & - & - & 170 & 20.2 \\
\hline & 11 & - & - & 105 & 12.5 \\
\hline & 12 & - & - & 103 & 12.2 \\
\hline & Total & - & - & 835 & 99.1 \\
\hline & Missing & - & - & 8 & 0.9 \\
\hline \multirow[t]{9}{*}{ School } & Bedford & - & - & 325 & 38.6 \\
\hline & Evan Hardy & - & - & 244 & 28.9 \\
\hline & Egnatoff & - & - & 148 & 17.6 \\
\hline & King George & - & - & 35 & 4.2 \\
\hline & Caswell & - & - & 39 & 4.6 \\
\hline & Westmount & - & - & 15 & 1.8 \\
\hline & Mayfair & - & - & 29 & 3.4 \\
\hline & Total & - & - & 835 & 99.1 \\
\hline & Missing & - & - & 8 & 0.9 \\
\hline \multirow{4}{*}{$\begin{array}{l}\text { Academic } \\
\text { performance }\end{array}$} & Above average & - & - & 58 & 6.9 \\
\hline & Average & - & - & 470 & 55.8 \\
\hline & Below average & - & - & 242 & 28.7 \\
\hline & Missing & - & - & 73 & 8.7 \\
\hline \multirow[t]{4}{*}{ Neighborhood SES } & High & - & - & 331 & 39.3 \\
\hline & Mid & - & - & 175 & 20.8 \\
\hline & Low & - & - & 224 & 26.6 \\
\hline & Missing & - & - & 113 & 13.4 \\
\hline \multirow{8}{*}{$\begin{array}{l}\text { Family Financial } \\
\text { Situation }\end{array}$} & Wealthy & - & - & 71 & 8.4 \\
\hline & Well-off & - & - & 246 & 29.2 \\
\hline & Comfortable & - & - & 284 & 33.7 \\
\hline & Adequate & - & - & 89 & 10.6 \\
\hline & Difficult & - & - & 36 & 4.3 \\
\hline & Poor & - & - & 2 & .2 \\
\hline & Unclassified & - & - & 34 & 4 \\
\hline & Missing & - & - & 81 & 9.6 \\
\hline \multirow[t]{6}{*}{ Self rated health } & Excellent & - & - & 173 & 20.5 \\
\hline & Very good & - & - & 290 & 34.4 \\
\hline & Good & - & - & 235 & 27.9 \\
\hline & Fair & - & - & 63 & 7.5 \\
\hline & Poor & - & - & 9 & 1.1 \\
\hline & Missing & - & - & 73 & 8.7 \\
\hline \multirow[t]{3}{*}{ Weight perception } & Overweight & - & - & 307 & 36.4 \\
\hline & Underweight & - & - & 448 & 53.1 \\
\hline & Missing & - & - & 88 & 10.4 \\
\hline
\end{tabular}

Note: The total of percentage may not sum to 100.0 due to rounding. 


\subsection{Derived Variable Constructs}

Principal components analysis (PCA) with oblique rotation was used to explore the factor structure of Self-efficacy, Self-esteem, Benefit of physical activity, Barriers to physical activity, Family's support, and Friend's support items. Oblique rotation, which allows the factors to be correlated, was used because the factors underlying these domains were expected to be correlated. Results from this analysis were saved as factor scores and used in the subsequent analysis of the relationship between each domain and participation in physical activity among adolescents. Factor names were derived to encompass the wording and the content making up the relevant items included in for each factor. Factor scores were derived by averaging the score of corresponding items.

\subsubsection{Psychosocial Factors}

The results of factor analysis for Self-efficacy and Self-esteem domains are presented in Table 4-2.

Factor Structure for Self-efficacy: The principal components analysis for expected outcomes yielded one factor with eigenvalues greater than 1 , accounting for $56.7 \%$ of the total variance. The factor was labeled Self efficacy, which contained six items. Cronbach's alpha reliability coefficient for the six items was 0.84 , indicating strong associations among the items.

Factor structure for Self-esteem: This domain included 9 items, with Cronbach's alpha reliability coefficient at 0.74 . The principal component analysis yielded two factors with eigenvalues greater than 1 , accounting for $49 \%$ of the total variance. The new derived factors were named: Diffidence and Self-confidence. 
Diffidence Factor included 5 items related to factors that demonstrated that adolescents were not confident about themselves and had a low self-regard: 'worry about what others think of', 'be too hard on oneself when make mistakes', 'feel like an outsider', 'wish to be someone else', and 'have trouble making decisions'. Selfconfidence Factor included 4 items: 'feel hopeful about future', 'like themselves', 'believe they can work things out if having a problem', and 'like how they look'. The Cronbach's alpha reliability coefficient for these factors were 0.67 and 0.65 , respectively.

Table 4-2. Factor Analysis Results for Psychosocial domain

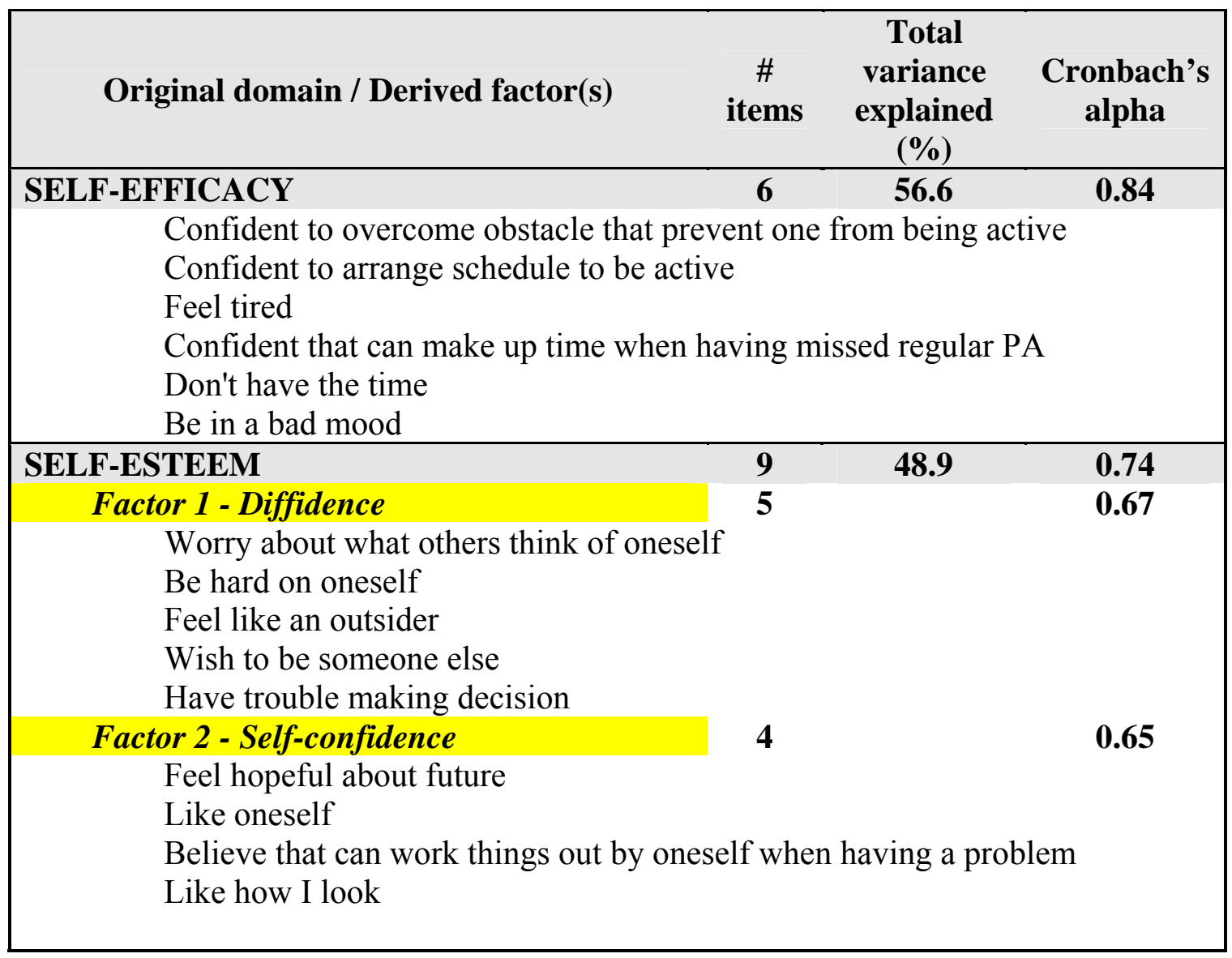




\subsubsection{Benefits of and Barriers to Physical Activity}

The results of factor analysis for Benefits of and Barriers to Physical Activity domains are presented in Table 4-3.

Factor structure of Benefits of Physical Activity: The Benefits of Physical Activity domain included 17 items and the Cronbach's alpha reliability coefficient was 0.82 , indicating strong associations among the items. Two items (physical activity is 'Competitive' and 'Easy'), however, were excluded because they had Corrected ItemTotal Correlation less than 3.5. Therefore, the principal component analysis was conducted in 15 items within the Benefits of Physical Activity domain. The principal component analysis yielded 4 factors with eigenvalues greater than 1 , accounting for $61.4 \%$ of the total variance. The four new derived factors were named: Improve Health, Improve Mental Health, Improve Social Relationship, and Improve Appearance.

Improve Health Factor included 4 items that indicate physical activity brings about benefits for health: 'improve fitness', 'improve health', 'get into shape', and ‘improve skills'. Improve Mental Health Factor included 6 items such as physical activity 'help to relieve boredom', 'give time to think', 'reduce worries', 'help to keep busy', 'make feel good', and 'be fun'. Improve Social Relationship Factor included 3 items, indicating physical activity help participants 'to be a part of a team/group', 'meet new people', and 'be with friends'. Improve Appearance Factor was composed of 2 items that indicate physical activity brings about appearance benefits for participants: 'improve appearance', and 'make look cool'. Cronbach's alpha reliability coefficient for Improve Health Factor was 0.85 , for Improve Mental Health Factor was 0.73 , for Improve Social 
Relationship Factor was 0.75, and for Improve Appearance Factor was 0.61, indicating good internal consistency among the items.

Factor Structure of Barriers to Physical Activity: The Barriers to Physical Activity domain includes 15 items, with Cronbach's alpha reliability coefficient was 0.83 , indicating good internal consistency. The principal component analysis for Barriers to Physical Activity domain yielded 4 factors with eigenvalues greater than 1, accounting for $56.5 \%$ of the total variance. Four factors were named: External Barriers, Motivational Barriers, Instrumental Barriers and Time Barriers.

External Barriers Factor included 5 items related primarily to barriers to physical activity such as 'unsafe environment', 'broken equipment', 'being obligated by family', 'physical activity settings were too crowded', and 'being injured by participating in physical activity'. Motivational Barriers Factor included 3 items related to factors that reduce the motivation to participate in physical activity in adolescents: 'didn't feel like', 'felt lazy', and 'interferes with social life'. Instrumental Barriers Factor included 3 items that indicate tangible barriers such as 'physical settings were not close to participants' home', 'couldn't get a ride' or 'didn't have money for physical activity'. Time Barriers include 2 items that indicate lacking of time for physical activity: 'didn't have enough time' and 'have too much homework to do'. Internal consistency within the 4 derived factors was good (Cronbach's alpha $=0.77$ for External Barriers Factor, 0.68 for Motivational Barriers Factor, 0.72 for Instrumental Barriers Factor and 0.6 for Time Barriers Factor). 
Table 4-3. Factor Analysis Results for Benefits of and Barriers to Physical Activity

\begin{tabular}{|c|c|c|c|}
\hline Original domain / Derived factor(s) & $\begin{array}{c}\# \\
\text { items }\end{array}$ & $\begin{array}{c}\text { Total } \\
\text { variance } \\
\text { explained } \\
(\%) \\
\end{array}$ & $\begin{array}{c}\text { Cronbach's } \\
\text { alpha }\end{array}$ \\
\hline \multirow{2}{*}{$\begin{array}{l}\text { BENEFITS OF PHYSICAL ACTIVITY (PA) } \\
\text { Factor } 1 \text { - Improve Health }\end{array}$} & 17 & 61.4 & 0.82 \\
\hline & 4 & & 0.85 \\
\hline \multicolumn{4}{|l|}{ PA improves fitness } \\
\hline \multicolumn{4}{|l|}{ PA improves health } \\
\hline \multicolumn{4}{|l|}{ PA gets into shape } \\
\hline \multicolumn{4}{|l|}{ PA help to improve kills } \\
\hline Factor 2 - Improve Mental Health & 6 & & 0.73 \\
\hline \multicolumn{4}{|l|}{ PA helps to relieve boredom } \\
\hline \multicolumn{4}{|l|}{ PA gives time to think } \\
\hline \multicolumn{4}{|l|}{ PA takes away worries } \\
\hline \multicolumn{4}{|l|}{ PA helps to keep busy } \\
\hline \multicolumn{4}{|l|}{ PA makes one feel good } \\
\hline \multicolumn{4}{|l|}{$\begin{array}{l}\text { PA is fun } \\
\text { Factor } 3 \text { - Improve Social Relationship }\end{array}$} \\
\hline Factor 3 - Improve Social Relationship & 3 & & 0.75 \\
\hline \multicolumn{4}{|l|}{ PA allows one to be part of a team } \\
\hline \multicolumn{4}{|l|}{ PA allows to meet new people } \\
\hline \multicolumn{4}{|l|}{ PA allows to be with friends } \\
\hline \multicolumn{4}{|l|}{$\begin{array}{c}\text { Factor } 4 \text { - Improve Appearance } \\
\text { PA makes one look cool }\end{array}$} \\
\hline \multirow{2}{*}{\multicolumn{4}{|c|}{$\begin{array}{l}\text { PA makes one look cool } \\
\text { PA improve appearance }\end{array}$}} \\
\hline & & & \\
\hline \multicolumn{4}{|l|}{ Variables not included in PCA } \\
\hline \multicolumn{4}{|l|}{ PA is competition } \\
\hline \multicolumn{4}{|l|}{ PA is easy } \\
\hline BARRIERS TO PHYSICAL ACTIVITY & 15 & 56.5 & 0.83 \\
\hline Factor 1 - External Barriers & 5 & & 0.77 \\
\hline \multicolumn{4}{|l|}{ PA area was not safe } \\
\hline \multicolumn{4}{|l|}{ Equipment was broken } \\
\hline \multicolumn{4}{|l|}{ Family obligates to participate in PA } \\
\hline \multicolumn{4}{|l|}{ Participants were injured } \\
\hline \multicolumn{4}{|l|}{ PA settings was too crowded } \\
\hline Factor 2 - Motivational Barriers & 3 & & 0.68 \\
\hline \multirow{2}{*}{\multicolumn{4}{|c|}{ Didn't feel like }} \\
\hline & & & \\
\hline \multicolumn{4}{|l|}{$\begin{array}{l}\text { Felt lazy } \\
\text { PA interferes social life }\end{array}$} \\
\hline \multicolumn{4}{|l|}{ Factor 3 - Instrumental Barriers } \\
\hline \multicolumn{4}{|l|}{ Activity is not close to one's home } \\
\hline No ride to PA settings & & & \\
\hline No money for PA & & & \\
\hline
\end{tabular}




\begin{tabular}{|c|c|c|c|}
\hline Original domain / Derived factor(s) & $\begin{array}{c}\# \\
\text { items }\end{array}$ & $\begin{array}{c}\text { Total } \\
\text { variance } \\
\text { explained } \\
(\%)\end{array}$ & $\begin{array}{c}\text { Cronbach's } \\
\text { alpha }\end{array}$ \\
\hline Factor 4 - Time Barriers & 2 & & 0.6 \\
\hline \multicolumn{4}{|l|}{ Have too much homework } \\
\hline \multicolumn{4}{|l|}{ Have not enough time for PA } \\
\hline Variables not included in PCA & 2 & & \\
\hline \multicolumn{4}{|l|}{ The weather was bad } \\
\hline \multicolumn{4}{|l|}{ PA makes one look uncool } \\
\hline
\end{tabular}

\subsubsection{Support from Family and Friends}

Table 4-4 showed the factor analysis results of Family's Support and Friend's support domain.

Factor structure of Family's Support: The Family's Support domain included 11 items. However, the item worded 'family upset with the physical activity that their adolescents did' had a meaning opposite to the other items within the domain (family didn't support for physical activity). Before conducting principal component analysis this item was reverse coded in order to be consistent with other items. Cronbach's alpha reliability coefficient for 11 items was 0.81 , indicating good internal consistency among the items. After two items ('family upset with the physical activity that adolescents did' and 'family order them to be physical activity') were dropped-because they had small Corrected ItemTotal Correlations-the Cronbach's alpha reliability coefficient for 9 items was 0.84 , indicating stronger association. The principal component analysis yielded 2 factors with eigenvalues greater than 1 , accounting for $56.5 \%$ of the total variance. They were named Family’s Indirect Support and Family’s Direct Support. 
Family's Indirect Support Factor included 5 items such as: Family 'offer to be physical activity with adolescents', 'talk about how physical activity is fun', 'participate in physical activity', 'teach skills for physical activity', and 'say physical activity was good for adolescents'. The Cronbach's alpha reliability coefficient for the items in this factor was 0.75 . Family's Direct Support Factor was composed 4 items: Family 'watch adolescents to be physical activity', 'pay for physical activity', 'say adolescents were good at physical activity', and 'encourage them to stick with physical activity'. Internal consistency within this factor was good (Cronbach's alpha $=0.78)$.

Factor structure for Friend's Support: This domain included 9 items, with Cronbach's alpha reliability coefficient was 0.85 , demonstrating strong internal consistency. The principal component analysis yielded one factor with eigenvalues greater than 1 , accounting for $44.8 \%$ of the total variance. 
Table 4-4. Factor Analysis Results for Family's Support and Friends' Support

\begin{tabular}{|lccc|}
\hline Original domain / Derived factor(s) & $\begin{array}{c}\text { \# } \\
\text { items }\end{array}$ & $\begin{array}{c}\text { Total } \\
\text { variance } \\
\text { explained } \\
\text { (\%) }\end{array}$ & $\begin{array}{c}\text { Cronbach's } \\
\text { alpha }\end{array}$ \\
\hline $\begin{array}{l}\text { FAMILY'S SUPPORT } \\
\text { Factor 1 - Family's Indirect Support }\end{array}$ & $\mathbf{1 1}$ & $\mathbf{5 6 . 5}$ & $\mathbf{0 . 8 1}$ \\
$\quad$ Family seen being PA & & $\mathbf{0 . 7 5}$ \\
Family says PA was good & & \\
Family offers to do PA with & & \\
Family teaches skills for PA & & \\
Family talks about how PA is fun & & \\
Factor 2 - Family's Direct Support & 4 & \\
Family watches adolescents do PA & & \\
Family says adolescents were good at PA & & \\
Family pays for PA & & \\
Family encourages adolescents to stick with PA & & \\
Variables not included in PCA & $\mathbf{2}$ & \\
Family upset with the PA adolescents did & & \\
Family orders adolescents to be PA & & \\
\hline FRIEND'S SUPPORT & & \\
Friends say adolescents were good at PA & & \\
Friends seen being PA & & \\
Friends say PA was good & & \\
Friends offer to do PA with & & \\
Friends order to do PA with & & \\
Friends teach skills for PA & & \\
Friends watch adolescents do PA & & \\
Friends encourage adolescents to stick with PA & & \\
Friends talk about how PA is fun & & \\
\end{tabular}




\subsection{Overweight and Obesity by Age and Sex}

Since the data for physical activity determinants as well as heights and weights measurements were available for two time points, BMI values were calculated at Time 1 and Time 3. Table 4-5 provides mean BMI values and the proportion of adolescents who were classified as overweight and obese, as defined by Cole and colleagues (2000), at Time 1 and Time 3 (separately by age group and sex). Figure 4.1 illustrates the distribution of overweight and obesity proportions at Time 1 and Time 3.

\section{Comparison of Average BMI}

Comparison of mean BMI between age groups: The average BMI for both boys and girls generally increased with age at both times. The mean BMI for girls in 15-16 and 17-18 age groups were significantly higher than that of 12-14 age group at either Time 1 or Time $3(\mathrm{p}<0.01)$. However, these increases were not statistically significant for girls. For boys the mean BMI significantly increased with age at Time $1(\mathrm{p}<0.05)$ (that is, mean BMI of 17-18 age group was greater than mean BMI of 15-16 age group which was greater than mean BMI of 12-14 age group). At Time 3, the mean BMI for boys in 15-16 and 17-18 age groups were significantly higher than that of 12-14 age group $(\mathrm{p}<0.01)$; no significant difference in mean BMI was found between 15-16 and 17-18 age groups ( $\mathrm{p}=$ 0.116). The comparisons of BMI between age groups for girls and boys are presented in

\section{Table 4-6a and Table 4-6b.}

Comparison of mean BMI between Sexs: At Time 1, the average BMI of girls was significantly lower than that of boys in 15-16 age group $(t=-2.048, \mathrm{df}=292, \mathrm{p}=$ $0.04)$ and in $17-18$ age groups $(t=-3.439, d f=216, p=0.001)$. No difference in the 
average BMI was found between sexs in 12-14 age group. At Time 3, no significant difference in mean BMI between boys and girls were observed among any of the three age groups compared. When comparing average BMI between Time 1 and Time 3, no significant difference was found between two sexs in each age group.

Table 4-5. Mean BMI and Proportion of Overweight/Obesity by Age and Sex at

Time 1 and Time 3

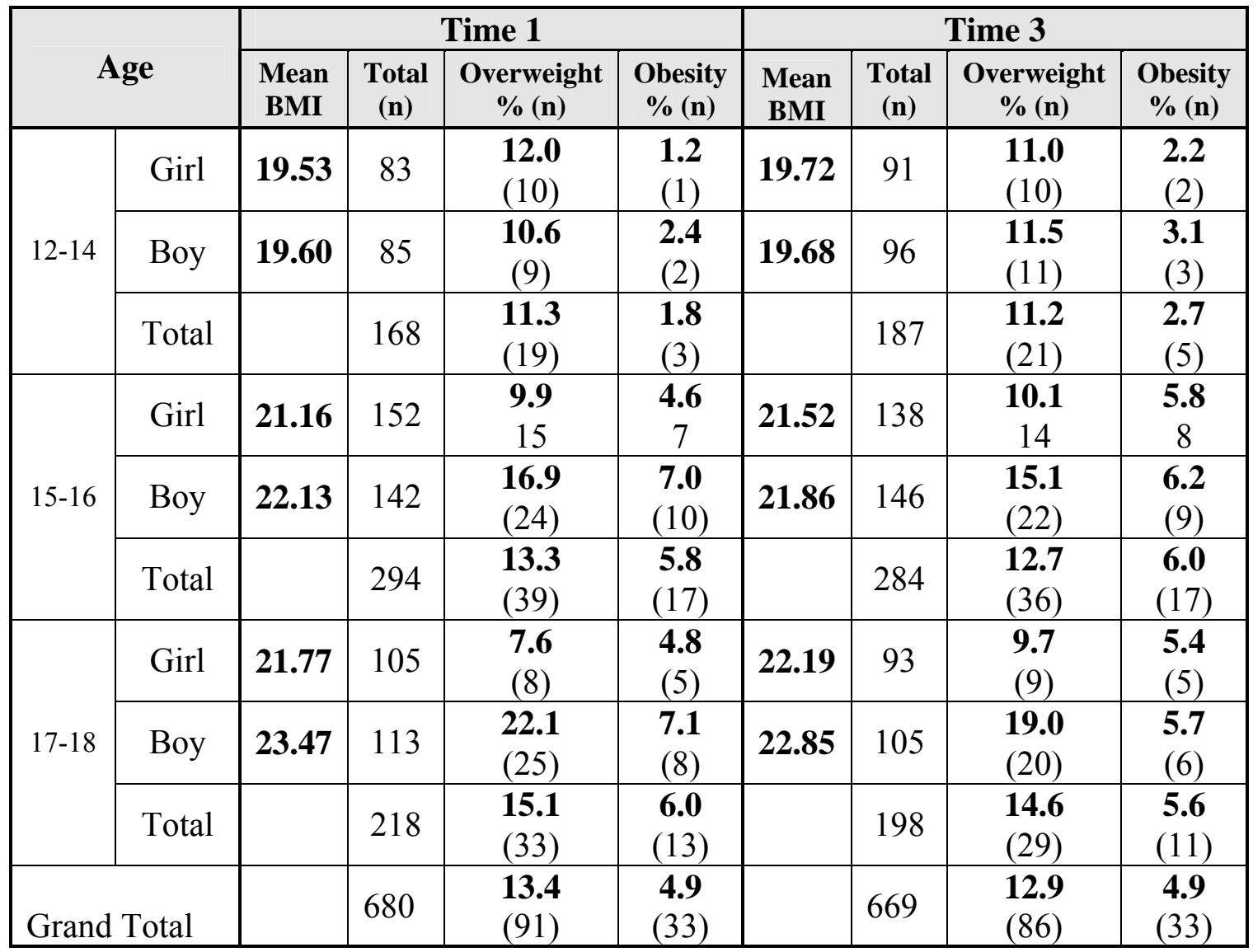


Figure 4-1. Distribution of Overweight/Obesity at Time 1 and Time 3
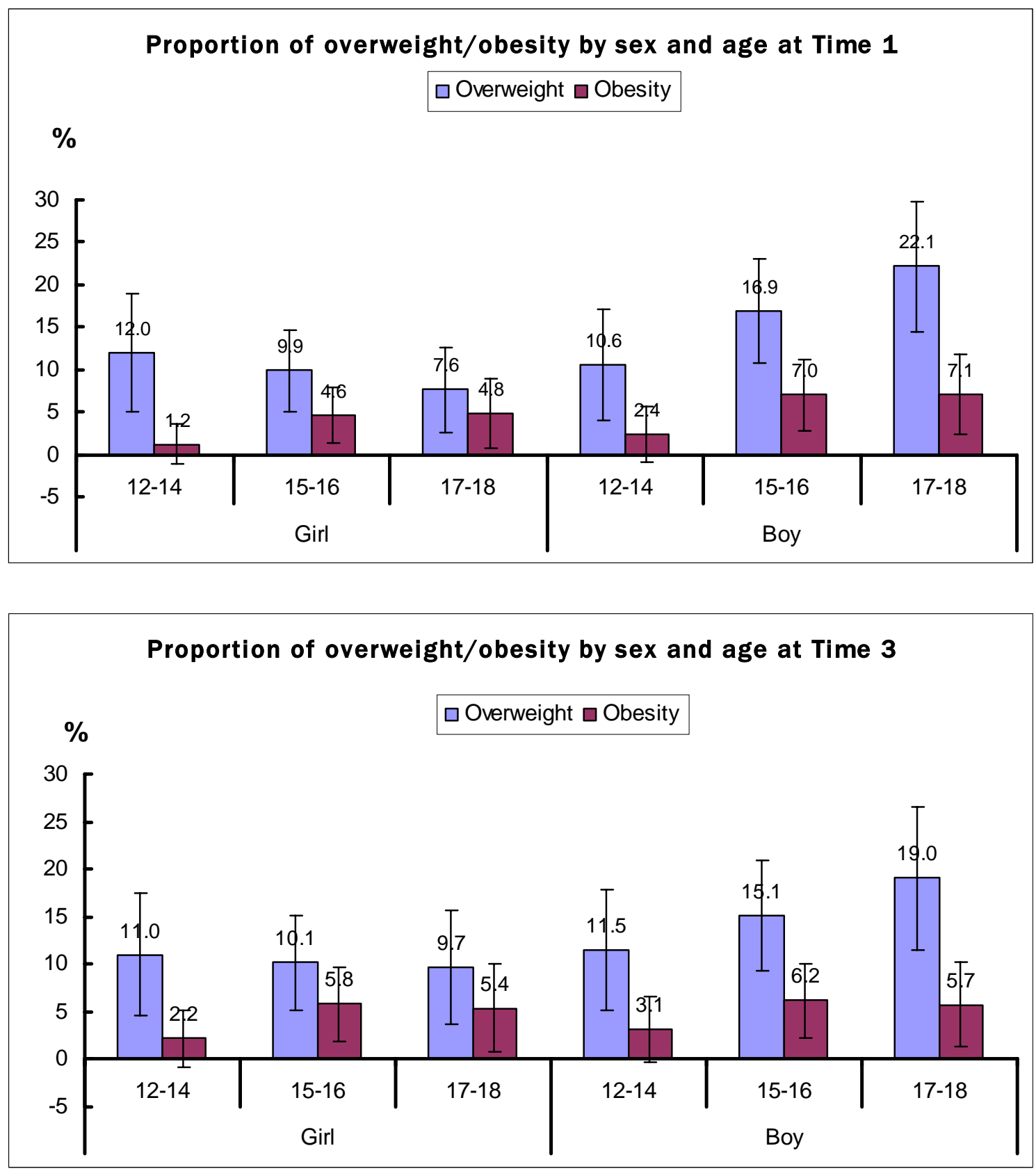
Table 4-6a \& b. Comparison of BMI between Age groups for girls and boys

Table 4-6a. Comparison of BMI between age-groups for girls

\begin{tabular}{|c|c|c|c|c|c|c|c|}
\hline \multirow{2}{*}{$\begin{array}{c}\text { Dependent } \\
\text { Variable }\end{array}$} & \multirow{2}{*}{\multicolumn{2}{|c|}{$\begin{array}{c}\text { Comparison } \\
\text { between } \\
\text { Age groups }\end{array}$}} & \multirow{3}{*}{$\begin{array}{c}\text { Mean } \\
\text { Difference } \\
\mathbf{- 1 . 6 2 5} \\
\end{array}$} & \multirow{3}{*}{$\begin{array}{l}\text { S.E. } \\
0.467\end{array}$} & \multirow{3}{*}{$\begin{array}{l}\text { Sig. } \\
0.002\end{array}$} & \multicolumn{2}{|c|}{ 95\% C.I. } \\
\hline & & & & & & \multirow{2}{*}{$\begin{array}{c}\text { Upper } \\
\text { Bound } \\
\mathbf{- 2 . 7 4 9}\end{array}$} & \multirow{2}{*}{$\begin{array}{l}\text { Lower } \\
\text { Bound } \\
\mathbf{- 0 . 5 0 1} \\
\end{array}$} \\
\hline \multirow{6}{*}{ Time $1 \mathrm{BMI}$} & \multirow{2}{*}{$12-14$} & $15-16$ & & & & & \\
\hline & & $17-18$ & -2.243 & 0.503 & 0.000 & -3.452 & -1.033 \\
\hline & \multirow{2}{*}{$15-16$} & $12-14$ & 1.625 & 0.467 & 0.002 & 0.501 & 2.749 \\
\hline & & $17-18$ & -0.617 & 0.434 & 0.468 & -1.662 & 0.427 \\
\hline & \multirow{2}{*}{$17-18$} & $12-14$ & 2.243 & 0.503 & 0.000 & 1.033 & 3.452 \\
\hline & & $15-16$ & 0.617 & 0.434 & 0.468 & -0.427 & 1.662 \\
\hline \multirow{6}{*}{ Time $3 \mathrm{BMI}$} & \multirow{2}{*}{$12-14$} & $15-16$ & -1.798 & 0.497 & 0.001 & -2.993 & -0.603 \\
\hline & & $17-18$ & -2.463 & 0.542 & 0.000 & -3.768 & -1.158 \\
\hline & \multirow{2}{*}{$15-16$} & $12-14$ & 1.798 & 0.497 & 0.001 & 0.603 & 2.993 \\
\hline & & $17-18$ & -0.665 & 0.493 & 0.536 & -1.852 & 0.522 \\
\hline & \multirow{2}{*}{$17-18$} & $12-14$ & 2.463 & 0.542 & 0.000 & 1.158 & 3.768 \\
\hline & & $15-16$ & 0.665 & 0.493 & 0.536 & -0.522 & 1.852 \\
\hline
\end{tabular}

Figures in bold text are statistically significant at $p<0.05$.

Table 4-6b. Comparison of BMI between Age-groups for boys

\begin{tabular}{|c|c|c|c|c|c|c|c|}
\hline \multirow{2}{*}{$\begin{array}{c}\text { Dependent } \\
\text { Variable }\end{array}$} & \multirow{2}{*}{\multicolumn{2}{|c|}{$\begin{array}{c}\text { Comparison } \\
\text { between } \\
\text { Age groups }\end{array}$}} & \multirow{3}{*}{$\begin{array}{c}\text { Mean } \\
\text { Difference } \\
-2.532 \\
\end{array}$} & \multirow{3}{*}{$\begin{array}{l}\text { S.E. } \\
0.541 \\
\end{array}$} & \multirow{3}{*}{$\begin{array}{l}\text { Sig. } \\
\mathbf{0 . 0 0 0}\end{array}$} & \multicolumn{2}{|c|}{ 95\% C.I. } \\
\hline & & & & & & \multirow{2}{*}{$\begin{array}{l}\text { Upper } \\
\text { Bound } \\
-3.832 \\
\end{array}$} & \multirow{2}{*}{$\begin{array}{l}\text { Lower } \\
\text { Bound } \\
\mathbf{- 1 . 2 3 1} \\
\end{array}$} \\
\hline \multirow{6}{*}{ Time $1 \mathrm{BMI}$} & \multirow{2}{*}{$12-14$} & $15-16$ & & & & & \\
\hline & & $17-18$ & -3.871 & 0.566 & 0.000 & -5.232 & -2.509 \\
\hline & \multirow{2}{*}{$15-16$} & $12-14$ & 2.532 & 0.541 & 0.000 & 1.231 & 3.832 \\
\hline & & $17-18$ & -1.339 & 0.497 & 0.022 & -2.535 & -0.144 \\
\hline & \multirow{2}{*}{$17-18$} & $12-14$ & 3.871 & 0.566 & 0.000 & 2.509 & 5.232 \\
\hline & & $15-16$ & 1.339 & 0.497 & 0.022 & 0.144 & 2.535 \\
\hline \multirow{6}{*}{ Time 3 BMI } & \multirow{2}{*}{$12-14$} & $15-16$ & -2.177 & 0.492 & 0.000 & -3.362 & -0.993 \\
\hline & & $17-18$ & -3.173 & 0.529 & 0.000 & -4.446 & -1.900 \\
\hline & \multirow{2}{*}{$15-16$} & $12-14$ & 2.177 & 0.492 & 0.000 & 0.993 & 3.362 \\
\hline & & $17-18$ & -0.996 & 0.480 & 0.116 & -2.150 & 0.158 \\
\hline & \multirow{2}{*}{$17-18$} & $12-14$ & 3.173 & 0.529 & 0.000 & 1.900 & 4.446 \\
\hline & & $15-16$ & 0.996 & 0.480 & 0.116 & -0.158 & 2.150 \\
\hline
\end{tabular}

Figures in bold text are statistically significant at $p<0.05$. 


\section{Prevalence of overweight and obesity}

At Time 1, the proportion of girls classified as obese increased with age. For boys, the proportion classified as overweight or obese increased as well with age. At Time 3, these patterns were less linear.

Chi-square tests were used to examine the association between overweight status and sex at each time point. At Time 1, boys and girls in younger age groups did not differ significantly in terms of being classified as overweight or obese. However, the proportion of boys and girls overweight/obese in the older age group (17-18 years) was significantly different. At Time 3, there were no significant differences in prevalence of overweight/obesity between sexs in all three age groups. The Chi-square test results are presented in Table 4-7a and Table 4-7b.

Between Time 1 and Time 3, the proportion of girls who were overweight and obese in 15-16 and 17-18 age groups increased. The same trend was seen for boys although the increased was less marked. In contrast, among 12-14 year boys, those considered overweight or obese were greater at Time 1 than that at Time 3 . The proportions of overweight/obesity are presented in Table 4-5. 
Table 4-7a \& b. Chi-square test results for Overweight/Obesity status by Sex and Age group at Time 1 and Time 3

Table 4-7a. at Time 1

\begin{tabular}{|c|c|c|}
\hline Age group & $\begin{array}{c}\text { Pearson Chi-square } \\
\text { (degrees of freedom) }\end{array}$ & $\begin{array}{c}\text { Significance (2- } \\
\text { sided) }\end{array}$ \\
\hline $12-14$ & $0.39(2)$ & 0.823 \\
\hline $15-16$ & $4.31(2)$ & 0.116 \\
\hline $17-18$ & $10.00(2)$ & 0.007 \\
\hline
\end{tabular}

Table 4-7b. at Time 3

\begin{tabular}{|c|c|c|}
\hline Age group & $\begin{array}{c}\text { Pearson Chi-square } \\
\text { (degrees of freedom) }\end{array}$ & $\begin{array}{c}\text { Significance (2- } \\
\text { sided) }\end{array}$ \\
\hline $12-14$ & $0.17(2)$ & 0.919 \\
\hline $15-16$ & $1.62(2)$ & 0.446 \\
\hline $17-18$ & $3.55(2)$ & 0.170 \\
\hline
\end{tabular}

In general, the average BMI for both adolescent boys and girls increased with age at both times. Compared with boys at Time 1, the mean BMI for girls was significantly lower in 15-16 and 17-18 age groups, while no difference in the average BMI was found in younger age group. At Time 3, no difference in mean BMI between sex were observed as well in all age groups. The proportion of girls classified as obese and the proportion of boys classified as overweight/obese increased with age at Time 1, however these patterns were less linear at Time 3. 


\subsection{Physical Activity Level}

\subsubsection{Physical Activity Levels Over Time}

Adolescents' physical activity patterns over five time points are presented in

Table 4-8 and are graphed in Figure 4-2. The proportion of adolescents reporting low levels of physical activity showed a steady increase over time (from $14.2 \%$ at Time 1 to $25 \%$ at Time 5). Correspondingly, proportion of adolescents reporting high levels of physical activity showed a downward trend over time although this trend was not monotonic (46.5\% at Time 1 drops to $30.3 \%$ at Time 3 , and increases to $34.8 \%$ at Time $5)$.

Table 4-8. Proportion (\%) of Adolescents' Physical Activity Levels at Five Time

\section{Points}

\begin{tabular}{|c|c|c|c|c|c|c|c|c|c|c|}
\hline \multirow{2}{*}{$\begin{array}{c}\text { Physical } \\
\text { activity } \\
\text { levels }\end{array}$} & \multicolumn{2}{|c|}{ Time 1} & \multicolumn{2}{|c|}{ Time 2} & \multicolumn{2}{|c|}{ Time 3} & \multicolumn{2}{|c|}{ Time 4} & \multicolumn{2}{|c|}{ Time 5} \\
\hline & Frequency & $\begin{array}{c}\text { Valid } \\
\%\end{array}$ & Frequency & $\begin{array}{c}\text { Valid } \\
\%\end{array}$ & Frequency & $\begin{array}{c}\text { Valid } \\
\%\end{array}$ & Frequency & $\begin{array}{c}\text { Valid } \\
\%\end{array}$ & Frequency & $\begin{array}{c}\text { Valid } \\
\%\end{array}$ \\
\hline Low & 110 & 14.2 & 149 & 20.7 & 154 & 20.8 & 142 & 19.9 & 169 & 25.0 \\
\hline Mod & 303 & 39.2 & 307 & 42.7 & 361 & 48.8 & 298 & 41.9 & 272 & 40.2 \\
\hline High & 359 & 46.5 & 263 & 36.6 & 224 & 30.3 & 272 & 38.2 & 235 & 34.8 \\
\hline Total & 772 & 100.0 & 719 & 100.0 & 739 & 100.0 & 712 & 100.0 & 676 & 100.0 \\
\hline
\end{tabular}


Figure 4-2. Proportion (\%) of Adolescents' Physical Activity Levels at Five Time

\section{Points}

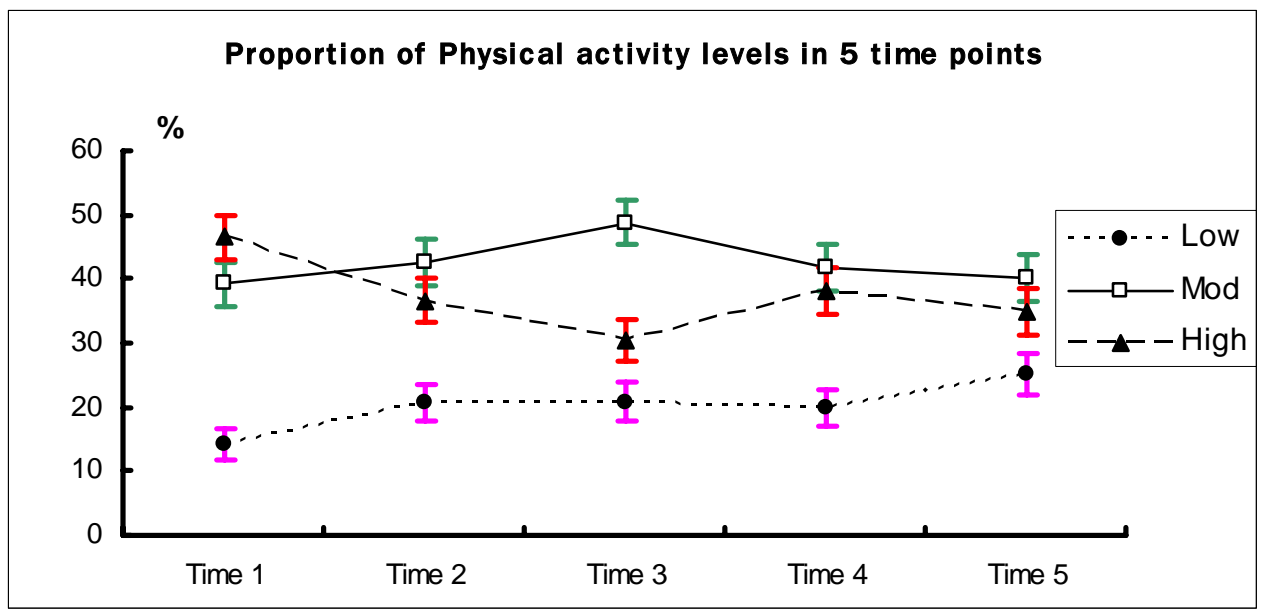

\subsubsection{Physical Activity Trends by Age and Sex}

When examining physical activity trends by age and sex, the proportion of girls who reported low physical activity levels showed a steady increase over time; this was true for all age groups. At the opposite end of the distribution, proportion of girls who reported high levels of physical activity showed notable decline over time for older age groups (17-18 years) but not as much for younger girls (12-14 or 15-16 years).

Among boys, only the oldest age group (17-18 years) showed a discernible increase in proportion of boys who reported low levels of physical activity; but such patterns were not seen among younger boys (12-14 or 15-16 years). However, boys in all age groups indicated a steady decrease of high levels of physical activity over time. The proportion (\%) and distribution of physical activity levels broken down by sex and age are demonstrated in Table 4-9 and Figure 4-3a, 4-3b, and 4-3c. 
Table 4-9. Proportion (\%) of Adolescents with Low, Moderate and High Physical Activity by Sex and Age

\begin{tabular}{|c|c|c|c|c|c|c|}
\hline \multicolumn{2}{|c|}{ Age at next birthday } & Time 1 & Time 2 & Time 3 & Time 4 & Time 5 \\
\hline \multicolumn{7}{|c|}{ Low physical activity level } \\
\hline \multirow{3}{*}{ Female } & $12-14$ & 12.61 & 17.86 & 15.38 & 17.12 & 27.43 \\
\hline & $15-16$ & 16.27 & 24.16 & 18.18 & 20.67 & 27.56 \\
\hline & $17-18$ & 17.95 & 25.24 & 32.04 & 31.18 & 38.89 \\
\hline \multirow{3}{*}{ Male } & $12-14$ & 9.80 & 19.05 & 15.60 & 18.52 & 12.77 \\
\hline & $15-16$ & 16.78 & 21.43 & 22.00 & 17.02 & 20.45 \\
\hline & $17-18$ & 10.34 & 15.38 & 23.58 & 18.10 & 24.14 \\
\hline \multicolumn{7}{|c|}{ Moderate physical activity level } \\
\hline \multirow{3}{*}{ Female } & $12-14$ & 45.38 & 43.75 & 53.85 & 41.44 & 35.40 \\
\hline & $15-16$ & 45.18 & 46.98 & 53.90 & 40.67 & 41.03 \\
\hline & $17-18$ & 44.44 & 46.60 & 43.69 & 45.16 & 37.78 \\
\hline \multirow{3}{*}{ Male } & $12-14$ & 34.31 & 43.81 & 51.38 & 34.26 & 44.68 \\
\hline & $15-16$ & 22.82 & 34.29 & 44.00 & 42.55 & 39.39 \\
\hline & $17-18$ & 44.83 & 41.35 & 45.28 & 47.62 & 43.68 \\
\hline \multicolumn{7}{|c|}{ High physical activity level } \\
\hline \multirow{3}{*}{ Female } & $12-14$ & 42.02 & 38.39 & 30.77 & 41.44 & 37.17 \\
\hline & $15-16$ & 38.55 & 28.86 & 27.92 & 38.67 & 31.41 \\
\hline & $17-18$ & 37.61 & 28.16 & 24.27 & 23.66 & 23.33 \\
\hline \multirow{3}{*}{ Male } & $12-14$ & 55.88 & 37.14 & 33.03 & 47.22 & 42.55 \\
\hline & $15-16$ & 60.40 & 44.29 & 34.00 & 40.43 & 40.15 \\
\hline & $17-18$ & 44.83 & 43.27 & 31.13 & 34.29 & 32.18 \\
\hline
\end{tabular}


Figures 4-3a-c. Distribution of Low, Moderate, and High Physical Activity Among Adolescents By Sex and Age Group.

Figure 4-3a. Distribution of Low Physical Activity
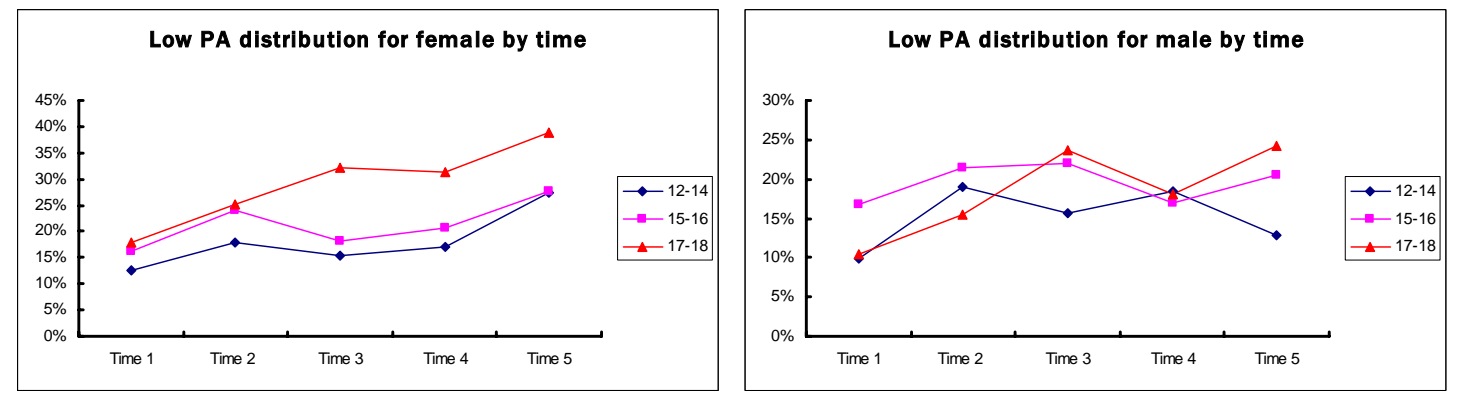

Figure 4-3b. Distribution of Moderate Physical Activity
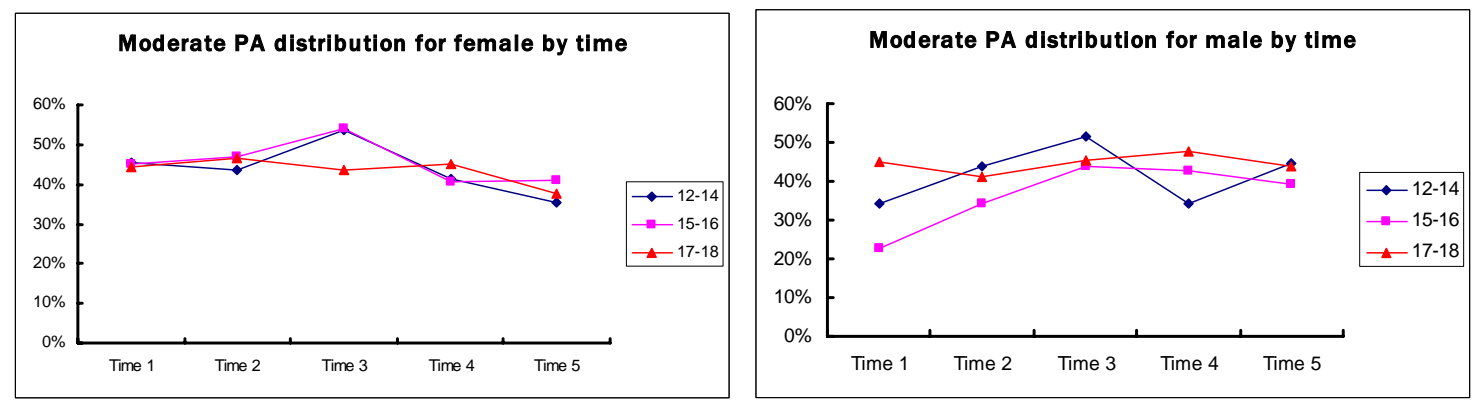

Figure 4-3c. Distribution of High Physical Activity
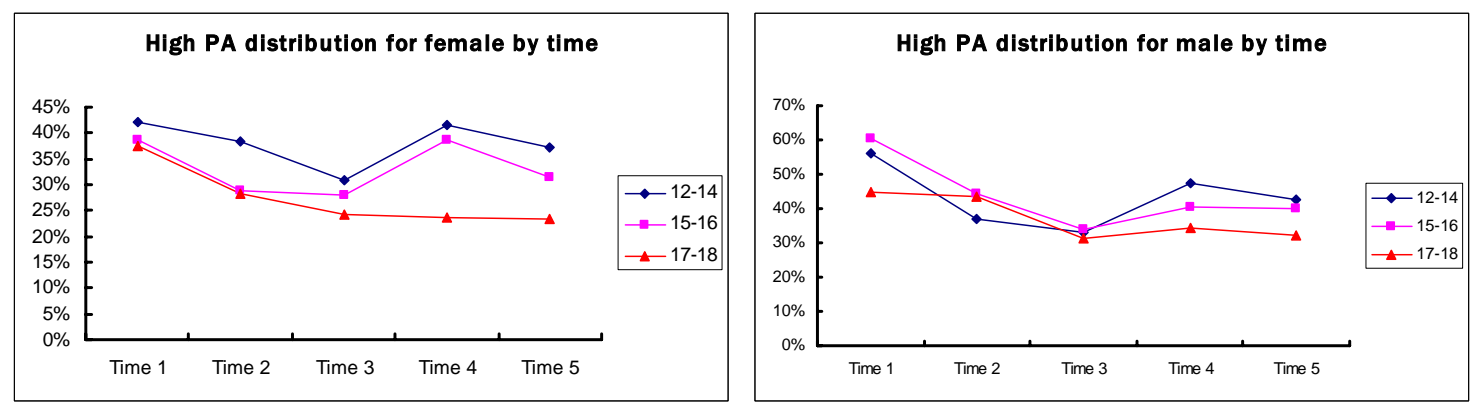


\subsubsection{Distribution of the Total Daily Energy Expenditure by Sex over Five}

Time Points

The mean total energy expenditure (KKD) for both sexes is shown in Table 4-10. The Figure 4-4 illustrates the distribution of mean KKD. Mean KKD showed a steady decline over 5 time points for both boys and girls. At Time 1 and 2 boys were shown a significantly higher mean KKD than girls $(\mathrm{p}<0.01)$. For Time 3,4 and 5 , there is no significant difference between the means KKD in boys and girls. The statistical t-test analyses of comparing mean energy expenditure between time points are shown in Table 4-11.

Table 4-10. Total Energy Expenditure (Mean KKD) by Sex at Five Time Points

\begin{tabular}{|c|l|c|c|c|c|}
\hline Time & Sex & $\mathbf{N}$ & Mean KKD & Std. Error & Std. Deviation \\
\hline \multirow{2}{*}{1} & Female & 429 & 7.96 & 0.39 & 8.08 \\
& Male & 406 & 10.12 & 0.48 & 9.75 \\
\hline \multirow{2}{*}{2} & Female & 429 & 5.84 & 0.33 & 6.83 \\
& Male & 406 & 7.21 & 0.39 & 7.80 \\
\hline \multirow{2}{*}{3} & Female & 429 & 5.72 & 0.30 & 6.30 \\
& Male & 406 & 6.56 & 0.33 & 6.74 \\
\hline \multirow{2}{*}{4} & Female & 429 & 6.22 & 0.38 & 7.81 \\
& Male & 406 & 6.82 & 0.33 & 6.67 \\
\hline \multirow{2}{*}{5} & Female & 429 & 5.49 & 0.35 & 7.32 \\
& Male & 406 & 5.94 & 0.34 & 6.91 \\
\hline
\end{tabular}


Figure 4-4. Distribution of Total Energy Expenditure (KKD) Over Five Time Points

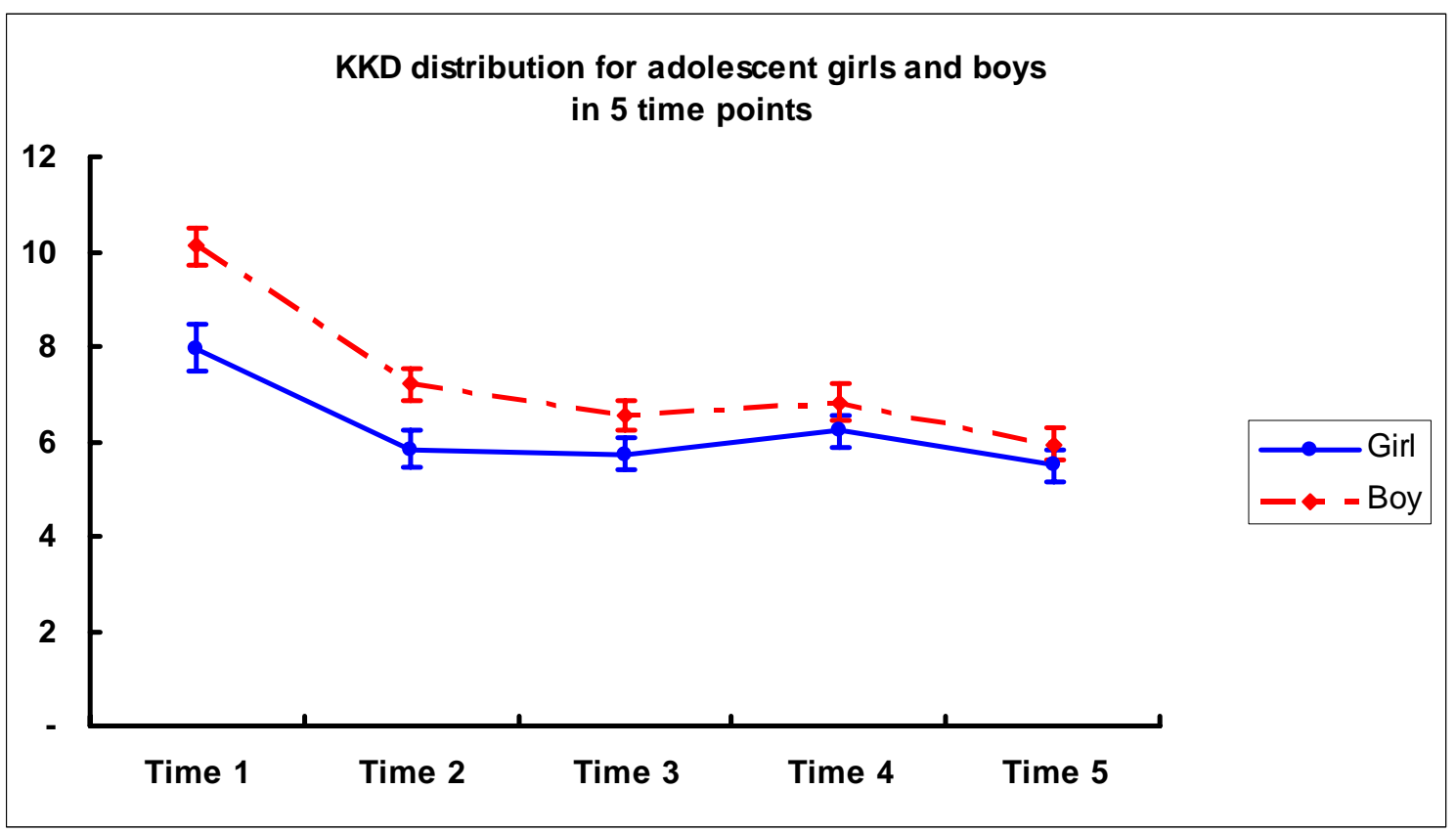

Table 4-11. Comparison of Total Energy Expenditure Scores Between Boys and Girls (t-test) Over Five Time Points

\begin{tabular}{|c|c|c|c|c|c|c|c|}
\hline Time & t-test & df & $\begin{array}{c}\text { p-value } \\
\mathbf{( 1 -} \\
\text { tailed) }\end{array}$ & $\begin{array}{c}\text { Mean Difference } \\
\text { between female } \\
\text { and male }\end{array}$ & $\begin{array}{c}\text { Std. Error } \\
\text { Difference }\end{array}$ & \multicolumn{2}{|c|}{$\begin{array}{c}\text { 95\% Confidence } \\
\text { Interval } \\
\text { of the Difference }\end{array}$} \\
\cline { 5 - 8 } & & $\mathbf{7 8 8}$ & $\mathbf{0 . 0 0 0}$ & $\mathbf{- 2 . 1 6 3}$ & $\mathbf{0 . 6 2 2}$ & -3.383 & $\mathbf{- 0 . 9 4 3}$ \\
$\mathbf{2}$ & $\mathbf{- 2 . 6 9 5}$ & $\mathbf{8 0 5}$ & $\mathbf{0 . 0 0 3}$ & $\mathbf{- 1 . 3 7 1}$ & $\mathbf{0 . 5 0 9}$ & $\mathbf{- 2 . 3 6 9}$ & $\mathbf{- 0 . 3 7 2}$ \\
$\mathbf{3}$ & $\mathbf{- 1 . 8 6 8}$ & $\mathbf{8 3 3}$ & $\mathbf{0 . 0 3 1}$ & $\mathbf{- 0 . 8 4 3}$ & $\mathbf{0 . 4 5 2}$ & $\mathbf{- 1 . 7 3 0}$ & $\mathbf{0 . 0 4 3}$ \\
$\mathbf{4}$ & -1.193 & 833 & 0.116 & -0.601 & 0.504 & -1.589 & 0.388 \\
$\mathbf{5}$ & -0.917 & 833 & 0.179 & -0.453 & 0.493 & -1.421 & 0.516 \\
\hline
\end{tabular}

The proportion of adolescents reporting low levels of physical activity showed a steady increase over time, while the proportion of adolescents reporting high levels of physical activity showed a downward trend over time. When examining physical activity trends by age and sex, the proportion of girls who reported low physical activity levels 
showed a steady increase over time at all age groups. The proportion of girls who reported high levels of physical activity showed remarkable decrease over time for 17-18 age group. Among boys, the proportion of boys who reported low levels of physical activity showed an apparent increase over time only in the 17-18 age group. The high levels of physical activity in all age groups for boys indicated a steady decrease over time.

When examining the distribution of the total daily energy expenditure (KKD) by sex, mean KKD showed a steady decline over time for both boys and girls. The mean KKD for boys were significantly higher than that for girls at Time 1, Time 2 and Time 3 only.

\subsection{Bivariate Associations: Physical Activity and Independent Variables}

The results of bivariate analysis are presented in Table 4-12. These findings are presented as general information prior to the multivariate results of predictors of physical activity.

In the bivariate analysis the following observations were found. Most predictor variables were significantly associated with physical activity. For instance, a negative association was found between physical activity and age, indicating declining physical activity with age; declining physical activity with age was more pronounced for girls compared to boys $(\mathrm{B}=-0.13, \mathrm{p}<0.01)$.

Support from family (including direct and indirect support) and friends, selfefficacy and self esteem showed positive relationships to physical activity in adolescents; family's direct support especially showed a stronger correlation with physical activity. 
Neighborhood and home environments, neighborhood safety and safety of travel to physical activity settings showed significantly positive correlations, indicating increase in physical activity participation in adolescents with more favourable characteristics of neighbourhood and home environments.

With respect to demographic variables, a positive correlation was observed between physical activity and family's financial situation and neighborhood's SES. 
Table 4-12. Bivariate Analysis Results Examining Association Between Physical Activity and Predictor Variables

\begin{tabular}{|c|c|c|c|}
\hline \multirow{2}{*}{ Variable } & \multicolumn{3}{|c|}{$\begin{array}{c}\text { Physical activity } \\
\text { (High=3, Mod=2, Low }=1)\end{array}$} \\
\hline & $\begin{array}{l}\text { Regression } \\
\text { coefficient }\end{array}$ & OR (95\% CI) & p-value \\
\hline Age & -0.04 & $0.96(0.94,0.99)$ & 0.00 \\
\hline $\begin{array}{r}\text { Age group } \\
17-18 \\
15-16 \\
12-14 \\
\end{array}$ & $\begin{array}{c}- \\
0.07 \\
0.12\end{array}$ & 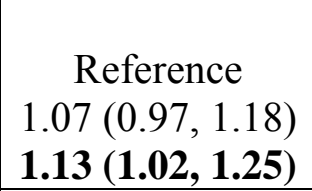 & $\begin{array}{l}- \\
0.17 \\
\mathbf{0 . 0 2}\end{array}$ \\
\hline $\begin{array}{l}\text { Sex } \\
\quad \text { Male } \\
\text { Female }\end{array}$ & -- & $\begin{array}{c}\text { Reference } \\
\mathbf{0 . 8 8}(\mathbf{0 . 8 1}, \mathbf{0 . 9 5})\end{array}$ & $\begin{array}{c}- \\
0.00\end{array}$ \\
\hline BMI & -0.02 & $0.98(0.97,1.00)$ & 0.00 \\
\hline $\begin{array}{l}\text { Weight perception } \\
\text { I think I'm underweight } \\
\text { I think I'm overweight }\end{array}$ & -0.06 & $\begin{array}{c}\text { Reference } \\
0.95(0.89,1.01)\end{array}$ & $\begin{array}{c}- \\
0.09 \\
\end{array}$ \\
\hline $\begin{array}{l}\text { Overweight or not } \\
\text { Overweight } \\
\text { Not overweight }\end{array}$ & $0 . \overline{20}$ & $\begin{array}{c}\text { Reference } \\
1.23(1.06,1.42)\end{array}$ & - \\
\hline $\begin{array}{l}\text { Benefits of Physical Activity } \\
\text { Improve Health } \\
\text { Improve Mental Health } \\
\text { Improve Social Relationship } \\
\text { Improve Appearance } \\
\text { Competition } \\
\text { Easy } \\
\text { Busy }\end{array}$ & $\begin{array}{c}0.15 \\
0.06 \\
0.08 \\
-0.004 \\
0.09 \\
-0.03 \\
0.05 \\
\end{array}$ & $\begin{array}{l}1.16(1.11,1.21) \\
1.06(1.02,1.11) \\
1.09(1.05,1.13) \\
1.00(0.96,1.03) \\
1.09(1.07,1.12) \\
0.97(0.94,1.00) \\
1.05(1.02,1.08) \\
\end{array}$ & $\begin{array}{l}\mathbf{0 . 0 0} \\
\mathbf{0 . 0 1} \\
\mathbf{0 . 0 0} \\
0.79 \\
\mathbf{0 . 0 0} \\
\mathbf{0 . 0 4} \\
\mathbf{0 . 0 0}\end{array}$ \\
\hline $\begin{array}{l}\text { Barriers to Physical Activity } \\
\text { External (Environment) } \\
\text { Motivational } \\
\text { Instrumental } \\
\text { Time } \\
\text { Weather } \\
\end{array}$ & $\begin{array}{l}-0.04 \\
-0.12 \\
-0.07 \\
-0.07 \\
-0.05\end{array}$ & $\begin{array}{l}0.96(0.93,0.99) \\
0.89(0.85,0.92) \\
0.93(0.90,0.96) \\
0.93(0.91,0.96) \\
0.95(0.93,0.97)\end{array}$ & $\begin{array}{l}0.01 \\
0.00 \\
0.00 \\
0.00 \\
0.00\end{array}$ \\
\hline $\begin{array}{l}\text { Look uncool } \\
\text { Number of barriers }\end{array}$ & $\begin{array}{l}-0.06 \\
-0.05\end{array}$ & $\begin{array}{l}0.95(0.91,0.98) \\
0.95(0.94,0.96)\end{array}$ & 0.00 \\
\hline $\begin{array}{l}\text { Family's support } \\
\text { Family's Indirect support } \\
\text { Family's Direct support }\end{array}$ & $\begin{array}{l}0.10 \\
0.21\end{array}$ & $\begin{array}{l}1.10(1.05,1.15) \\
1.24(1.20,1.28)\end{array}$ & $\begin{array}{l}0.00 \\
0.00\end{array}$ \\
\hline Friend's support & 0.16 & $1.17(1.13,1.23)$ & 0.00 \\
\hline Self-efficacy & 0.03 & $1.03(1.02,1.04)$ & 0.00 \\
\hline
\end{tabular}




\begin{tabular}{|c|c|c|c|}
\hline \multirow{2}{*}{ Variable } & \multicolumn{3}{|c|}{$\begin{array}{c}\text { Physical activity } \\
(\text { High }=3, \text { Mod=2, Low }=1)\end{array}$} \\
\hline & $\begin{array}{c}\text { Regression } \\
\text { coefficient }\end{array}$ & OR $(95 \% \mathrm{CI})$ & p-value \\
\hline $\begin{array}{l}\text { Self esteem } \\
\text { Diffidence } \\
\text { Self-confidence }\end{array}$ & $\begin{array}{l}0.10 \\
0.09\end{array}$ & $\begin{array}{l}1.11(1.05,1.17) \\
1.09(1.04,1.15)\end{array}$ & $\begin{array}{l}0.00 \\
0.00\end{array}$ \\
\hline $\begin{array}{l}\text { Neighborhood Environment } \\
\text { Score }\end{array}$ & 0.03 & $1.03(1.01,1.05)$ & 0.02 \\
\hline Home environment score & 0.05 & $1.05(1.03,1.07)$ & 0.00 \\
\hline Convenient facilities & 0.02 & $1.02(1.01,1.03)$ & 0.00 \\
\hline $\begin{array}{l}\text { Neighbourhood Safety } \\
\text { Very Safe } \\
\text { Somewhat Safe } \\
\text { Safe } \\
\text { Somewhat Unsafe } \\
\text { Very Unsafe }\end{array}$ & $\begin{array}{l}- \\
-0.09 \\
-0.13 \\
-0.10 \\
-0.34\end{array}$ & $\begin{array}{c}\text { Reference } \\
\mathbf{0 . 9 2}(\mathbf{0 . 8 5}, \mathbf{1 . 0 0}) \\
\mathbf{0 . 8 8}(\mathbf{0 . 8 0 , 0 . 9 6 )} \\
0.91(0.79,0.95) \\
\mathbf{0 . 7 1}(\mathbf{0 . 5 9 , 0 . 8 7 )}\end{array}$ & $\begin{array}{l}- \\
\mathbf{0 . 0 4} \\
\mathbf{0 . 0 1} \\
0.19 \\
\mathbf{0 . 0 0}\end{array}$ \\
\hline $\begin{array}{l}\text { Safety of travel } \\
\text { Very Safe } \\
\text { Somewhat Safe } \\
\text { Safe } \\
\text { Somewhat Unsafe } \\
\text { Very Unsafe }\end{array}$ & $\begin{array}{l}- \\
-0.07 \\
-0.17 \\
-0.21 \\
-0.24\end{array}$ & $\begin{array}{c}\text { Reference } \\
\mathbf{0 . 9 3}(\mathbf{0 . 8 7}, \mathbf{1 . 0 0}) \\
\mathbf{0 . 8 5}(\mathbf{0 . 7 8 , 0 . 9 1 )} \\
\mathbf{0 . 8 1}(\mathbf{0 . 7 0 , 0 . 9 4 )} \\
0.78(0.61,1.01)\end{array}$ & $\begin{array}{l}- \\
\mathbf{0 . 0 4} \\
\mathbf{0 . 0 0} \\
\mathbf{0 . 0 1} \\
0.06\end{array}$ \\
\hline $\begin{array}{l}\text { Neighborhood's SES } \\
\text { Low SES } \\
\text { Moderate SES } \\
\text { High SES } \\
\end{array}$ & $\begin{array}{l}- \\
0.17 \\
0.26 \\
\end{array}$ & $\begin{array}{c}\text { Reference } \\
1.19(1.06,1.33) \\
1.29(1.17,1.42)\end{array}$ & $\begin{array}{c}- \\
0.00 \\
0.00\end{array}$ \\
\hline Family's financial situation & 0.03 & $1.03(1.00,1.05)$ & 0.04 \\
\hline $\begin{array}{l}\text { Academic performance } \\
\text { Below average } \\
\text { Average } \\
\text { Above average } \\
\end{array}$ & $\begin{array}{c}- \\
-0.09 \\
-0.24 \\
\end{array}$ & $\begin{array}{c}\text { Reference } \\
0.92(0.85,0.99) \\
0.78(0.69,0.89)\end{array}$ & $\begin{array}{c}- \\
0.02 \\
0.00\end{array}$ \\
\hline $\begin{array}{l}\text { Self rated health } \\
\text { Excellent } \\
\text { Very good } \\
\text { Good } \\
\text { Fair } \\
\text { Poor }\end{array}$ & $\begin{array}{c}- \\
-0.02 \\
-0.13 \\
-0.34 \\
-0.51\end{array}$ & $\begin{array}{c}\text { Reference } \\
0.98(0.79,0.92) \\
0.88(0.80,0.97) \\
0.71(0.63,0.81) \\
0.60(0.49,0.73)\end{array}$ & $\begin{array}{l}- \\
0.00 \\
0.01 \\
0.00 \\
0.00\end{array}$ \\
\hline
\end{tabular}

Figures in bold text are statistically significant at $p<0.05$. 


\subsection{Determinants of Changing Physical Activity Patterns}

Multivariate GEE analysis was used to determine what characteristics overall were important for physical activity in this study. Variables that were significant at $\mathrm{p}<0.05$ in the bivariate analyses and those variables which were clinically important were included in the multivariate analyses for physical activity.

The full model which includes all predictors of high physical activity over time is presented in Table 4-13. 
Table 4-13. Factors Associated with High Level of Physical Activity Over Time in

Adolescents in Saskatoon

\begin{tabular}{|c|c|c|c|c|c|}
\hline \multirow[t]{2}{*}{ Parameter } & \multirow[t]{2}{*}{$\begin{array}{l}\text { Regression } \\
\text { coefficient }\end{array}$} & \multirow[t]{2}{*}{ Std.Error } & \multirow[t]{2}{*}{$\begin{array}{c}\text { Relative } \\
\text { Risk }\end{array}$} & \multicolumn{2}{|c|}{$\begin{array}{c}95 \% \\
\text { Confidence } \\
\text { Interval for } \\
\text { Relative Risk }\end{array}$} \\
\hline & & & & Lower & Upper \\
\hline (Intercept) & 2.046 & 0.573 & 7.739 & 2.519 & 23.779 \\
\hline $\begin{array}{l}\text { Sex } \\
\quad \text { Male } \\
\text { Female }\end{array}$ & $\begin{array}{c}- \\
-0.140\end{array}$ & 0.055 & $\begin{array}{c}\text { Reference } \\
\mathbf{0 . 8 7 0}\end{array}$ & $\begin{array}{c}\cdot \\
0.781\end{array}$ & 0.968 \\
\hline $\begin{array}{l}\text { Neighborhood safety } \\
\text { Very Safe } \\
\text { Somewhat Safe } \\
\text { Safe } \\
\text { Somewhat Unsafe } \\
\text { Very Unsafe } \\
\end{array}$ & $\begin{array}{c}- \\
0.034 \\
-0.042 \\
\mathbf{0 . 2 7 7} \\
0.130 \\
\end{array}$ & $\begin{array}{c}\cdot \\
0.066 \\
0.092 \\
0.133 \\
0.230 \\
\end{array}$ & $\begin{array}{c}\text { Reference } \\
1.034 \\
0.959 \\
\mathbf{1 . 3 1 9} \\
1.139 \\
\end{array}$ & $\begin{array}{l}0.908 \\
0.801 \\
\mathbf{1 . 0 1 7} \\
0.726 \\
\end{array}$ & $\begin{array}{l}1.178 \\
1.149 \\
\mathbf{1 . 7 1 1} \\
1.787 \\
\end{array}$ \\
\hline $\begin{array}{l}\text { Safety of travel } \\
\text { Very Safe } \\
\text { Somewhat Safe } \\
\text { Safe } \\
\text { Somewhat Unsafe } \\
\text { Very Unsafe } \\
\end{array}$ & $\begin{array}{c}- \\
0.019 \\
-0.028 \\
\mathbf{- 0 . 2 9 7} \\
-0.166 \\
\end{array}$ & $\begin{array}{c}. \\
0.063 \\
0.077 \\
0.141 \\
0.362 \\
\end{array}$ & $\begin{array}{c}\text { Reference } \\
1.019 \\
0.972 \\
\mathbf{0 . 7 4 3} \\
0.847 \\
\end{array}$ & $\begin{array}{l}0.902 \\
0.837 \\
\mathbf{0 . 5 6 4} \\
0.417 \\
\end{array}$ & $\begin{array}{c}\cdot \\
1.153 \\
1.130 \\
\mathbf{0 . 9 8 0} \\
1.722 \\
\end{array}$ \\
\hline $\begin{array}{l}\text { Neighborhood SES } \\
\text { Low SES } \\
\text { Moderate SES } \\
\text { High SES }\end{array}$ & $\begin{array}{c}- \\
0.048 \\
-0.015\end{array}$ & $\begin{array}{c}. \\
0.074 \\
0.073\end{array}$ & $\begin{array}{c}\text { Reference } \\
1.050 \\
0.985\end{array}$ & $\begin{array}{c}\cdot \\
0.908 \\
0.854\end{array}$ & $\begin{array}{c}. \\
1.213 \\
1.137\end{array}$ \\
\hline $\begin{array}{l}\text { Overweight Status } \\
\text { Obesity } \\
\text { Overweight } \\
\text { Healthy Weight } \\
\end{array}$ & $\begin{array}{c}- \\
-0.277 \\
-0.337 \\
\end{array}$ & $\begin{array}{c}\cdot \\
0.149 \\
0.179 \\
\end{array}$ & $\begin{array}{c}\text { Reference } \\
0.758 \\
0.714 \\
\end{array}$ & $\begin{array}{c}\cdot \\
0.566 \\
0.502 \\
\end{array}$ & $\begin{array}{c}. \\
1.015 \\
1.014 \\
\end{array}$ \\
\hline $\begin{array}{l}\text { Self rated health } \\
\text { Excellent } \\
\text { Very Good } \\
\text { Good } \\
\text { Fair } \\
\text { Poor } \\
\end{array}$ & $\begin{array}{c}- \\
-0.097 \\
-0.023 \\
-0.085 \\
-0.216 \\
\end{array}$ & $\begin{array}{l}0.061 \\
0.075 \\
0.118 \\
0.216 \\
\end{array}$ & $\begin{array}{c}\text { Reference } \\
0.907 \\
0.977 \\
0.918 \\
0.806 \\
\end{array}$ & $\begin{array}{c}\cdot \\
0.804 \\
0.843 \\
0.729 \\
0.528 \\
\end{array}$ & $\begin{array}{c}\cdot \\
1.023 \\
1.132 \\
1.156 \\
1.230 \\
\end{array}$ \\
\hline
\end{tabular}




\begin{tabular}{|c|c|c|c|c|c|}
\hline \multirow[t]{2}{*}{ Parameter } & \multirow[t]{2}{*}{$\begin{array}{l}\text { Regression } \\
\text { coefficient }\end{array}$} & \multirow[t]{2}{*}{ Std.Error } & \multirow[t]{2}{*}{$\begin{array}{l}\text { Relative } \\
\text { Risk }\end{array}$} & \multicolumn{2}{|c|}{$\begin{array}{c}95 \% \\
\text { Confidence } \\
\text { Interval for } \\
\text { Relative Risk } \\
\end{array}$} \\
\hline & & & & Lower & Upper \\
\hline \multicolumn{6}{|l|}{ Academic performance } \\
\hline Below Average & - & . & Reference & . & . \\
\hline Average & -0.031 & 0.054 & 0.970 & 0.873 & 1.077 \\
\hline Above Average & -0.063 & 0.121 & 0.939 & 0.741 & 1.189 \\
\hline Age & 0.018 & 0.019 & 1.018 & 0.981 & 1.056 \\
\hline BMI & -0.021 & 0.012 & 0.979 & 0.956 & 1.002 \\
\hline \multicolumn{6}{|l|}{ Benefits of Physical Activity } \\
\hline Improve Mental Health & -0.055 & 0.044 & 0.947 & 0.869 & 1.031 \\
\hline Improve Health & 0.058 & 0.040 & 1.060 & 0.980 & 1.146 \\
\hline Improve Social Relationship & -0.002 & 0.030 & 0.998 & 0.941 & 1.059 \\
\hline $\mathrm{PA}$ is competitive & 0.057 & 0.020 & 1.059 & 1.018 & 1.102 \\
\hline PA is easy & -0.059 & 0.024 & 0.943 & 0.899 & 0.989 \\
\hline PA helps one to keep busy & 0.025 & 0.026 & 1.025 & 0.975 & 1.078 \\
\hline \multicolumn{6}{|l|}{ Barriers to Physical Activity } \\
\hline External & 0.040 & 0.046 & 1.041 & 0.951 & 1.138 \\
\hline Motivational & -0.018 & 0.042 & 0.982 & 0.905 & 1.066 \\
\hline Instrumental & 0.030 & 0.036 & 1.030 & 0.960 & 1.105 \\
\hline Time & -0.018 & 0.031 & 0.982 & 0.925 & 1.043 \\
\hline Weather & 0.003 & 0.023 & 1.003 & 0.958 & 1.050 \\
\hline Look Uncool & -0.019 & 0.033 & 0.981 & 0.920 & 1.047 \\
\hline Number of barriers & -0.025 & 0.020 & 0.976 & 0.938 & 1.014 \\
\hline \multicolumn{6}{|l|}{ Family’s Support } \\
\hline Family's Indirect Support & -0.081 & 0.039 & 0.922 & 0.853 & 0.996 \\
\hline Family's Direct Support & 0.208 & 0.033 & 1.231 & 1.153 & 1.313 \\
\hline Friend's Support & 0.056 & 0.036 & 1.058 & 0.985 & 1.136 \\
\hline Self efficacy & 0.019 & 0.007 & 1.019 & 1.007 & 1.033 \\
\hline \multicolumn{6}{|l|}{ Self-esteem } \\
\hline Diffidence & 0.022 & 0.043 & 1.022 & 0.940 & 1.111 \\
\hline Self confidence & -0.069 & 0.044 & 0.934 & 0.856 & 1.018 \\
\hline Neighborhood Environment & -0.011 & 0.020 & 0.989 & 0.951 & 1.028 \\
\hline Home Environment & 0.026 & 0.013 & 1.026 & 1.001 & 1.052 \\
\hline Convenient Facilities & 0.011 & 0.010 & 1.011 & 0.991 & 1.030 \\
\hline $\begin{array}{l}\text { Family's Financial } \\
\text { Situation }\end{array}$ & 0.006 & 0.022 & 1.006 & 0.963 & 1.050 \\
\hline
\end{tabular}

Figures in bold text are statistically significant at $p<0.05$. 
After excluding all variables that were not statistically significant in the full main effect model, the final main effect model that included only the variables that were significantly related to physical activity in the full effect model was built. The results are presented in Table 4-14.

The variables in the final model included: sex, perceived benefits that physical activity is competitive and easy, family's indirect support, family's direct support, self efficacy and home environment score. The main findings from the final multivariate analysis are summarized below:

1) Compared to boys, girls were $8 \%$ less likely to be physically active over time (Relative odds $0.92 ; 95 \%$ CI $0.88,0.96$ ).

2) Adolescent boys and girls who indicated that engaging in physical activity conferred the benefit of being competitive were more likely to engage in physical activity over time. In contrast adolescents who indicated that engaging in physical activity was "easy" were less likely to engage in physical activity over time.

3) Adolescent boys and girls who indicated that they received indirect support from their family were $5.4 \%$ less likely to be physically active over time (Relative odds 0.94; 95\% CI 0.91, 0.98).

4) Conversely, adolescents who indicated that they received direct support from family were $21 \%$ more likely to be physically active over time (Relative odds $1.21 ; 95 \%$ CI $1.17,1.24)$.

5) Adolescents who indicated high degree of self efficacy were $3 \%$ more likely to engage in physically active over time (Relative odds $1.03 ; 95 \%$ CI 1.02, 1.04). 
6) Adolescents who indicated that they had access to more equipment for physical activity at home were $4 \%$ more likely to engage in physical activity over time (Relative odds 1.04; 95\% CI 1.03, 1.05).

Table 4-14. Final Main Effect Model Examining Factors Associated with High Physical Activity Over Time in Adolescents in Saskatoon

\begin{tabular}{|c|c|c|c|c|c|}
\hline \multirow[t]{2}{*}{ Parameter } & \multirow[t]{2}{*}{$\begin{array}{l}\text { Regression } \\
\text { Coefficient }\end{array}$} & \multirow[t]{2}{*}{ Std.Error } & \multirow[t]{2}{*}{$\begin{array}{l}\text { Relative } \\
\text { Risk }\end{array}$} & \multicolumn{2}{|c|}{$\begin{array}{c}95 \% \\
\text { Confidence } \\
\text { Interval for } \\
\text { Relative Risk } \\
\end{array}$} \\
\hline & & & & Lower & Upper \\
\hline (Intercept) & 1.232 & 0.061 & 3.428 & 3.040 & 3.866 \\
\hline \multicolumn{6}{|l|}{ Sex } \\
\hline Male & - & . & Reference & . & \\
\hline Female & -0.083 & 0.023 & 0.921 & 0.880 & 0.964 \\
\hline $\begin{array}{l}\text { Perceived benefit of PA: } \\
\text { competitive }\end{array}$ & 0.070 & 0.009 & 1.072 & 1.053 & 1.092 \\
\hline $\begin{array}{l}\text { Perceived benefit of PA: } \\
\text { easy }\end{array}$ & -0.059 & 0.010 & 0.943 & 0.924 & 0.962 \\
\hline Family's Indirect Support & -0.055 & 0.018 & 0.946 & 0.914 & 0.980 \\
\hline Family's Direct Support & 0.189 & 0.015 & 1.208 & 1.174 & 1.243 \\
\hline Self efficacy & 0.030 & 0.004 & 1.030 & 1.023 & 1.037 \\
\hline Home Environment & 0.038 & 0.005 & 1.038 & 1.028 & 1.049 \\
\hline
\end{tabular}




\section{DISCUSSION}

The purpose of this analysis was to determine how physical activity and overweight/obesity change overtime and to identify factors associated with change in physical activity in this sample. The following discussion considers results found for each research question. The strengths and limitations of the study are also discussed.

\subsection{Physical Activity, Overweight/Obesity Patterns Over Time, and by Sex}

How do physical activity and overweigh/obesity change over time in a cohort of adolescents in Saskatoon? Are there differences in the patterns of change in overweight/obesity and physical activity between boys and girls?

\section{Overweight/obesity status}

In the current study, the overall prevalence of overweight and obesity was similar at each of the two time points, Time 1 and Time 3 . At Time 1, the overall prevalence of overweight and obesity was $13.4 \%$ and $4.9 \%$, respectively. At Time 2 , the comparable proportions were $12.9 \%$ and $4.9 \%$, respectively.

Findings from the 2004 Canadian Community Health Survey ${ }^{159}$ (CCHS) - this survey used the same international standard for BMI values for overweight and obesity proposed by Cole et al. ${ }^{54}$-reported an overall prevalence of $19.8 \%$ for overweight, and 9.4\% for obesity, for youth aged 12-17 years. The comparable prevalence from 1978/79 Canada Health Survey (CHS) was $11 \%$ for overweight and $3 \%$ for obesity. ${ }^{159}$ The current findings for overall prevalence of overweight and obesity were lower than those reported in the 2004 CCHS by Shields, ${ }^{159}$ and higher than prevalence figures reported in the 
1978/79 CHS. The prevalence of overweight and obesity for youth aged 12-17 reported from previous and current studies are detailed in Table 5-1.

Table 5-1. Prevalence of Overweight and Obesity in the 1978/79 CHS, 2004 CCHS and the Current Study

\begin{tabular}{|c|c|c|c|c|c|c|c|c|c|c|}
\hline & \multicolumn{3}{|c|}{ Overweight (\%) } & \multicolumn{3}{|c|}{ Obese (\%) } & \multicolumn{3}{|c|}{ Overweight/Obese (\%) } \\
\hline & & Girls & Boys & Total & Girls & Boys & Total & Girls & Boys & Total \\
\hline \multicolumn{2}{|c|}{ 1978/79 CHS } & $\begin{array}{c}\text { Not } \\
\text { available }\end{array}$ & NA & 11 & NA & NA & 3 & NA & NA & 14 \\
\hline \multicolumn{2}{|c|}{2004 CCHS } & 18.3 & 21.1 & 19.8 & 7.4 & 11.1 & 9.4 & 25.8 & 32.3 & 29.2 \\
\hline \multirow{2}{*}{$\begin{array}{l}\text { Current } \\
\text { study }\end{array}$} & Time 1 & 9.7 & 17.1 & 13.4 & 3.8 & 5.9 & 4.9 & 13.5 & 22.9 & 18.2 \\
\hline & Time 3 & 10.2 & 15.3 & 12.9 & 4.7 & 5.2 & 4.9 & 14.9 & 20.5 & 17.8 \\
\hline
\end{tabular}

The differences in prevalence of overweight and obesity among youth 12-17 years of age between the current study and the two Canadian surveys could be due to the variations in the methods used to collect information on height and weight, the difference in the time of data collection and the survey's scale. The height and weight of adolescents in the 1978/79 CHS and 2004 CCHS were collected based on direct measurement, while the height and weight measures in the current study were collected based on self-reported data. The results of Cairney et al. suggested that the prevalence estimates for obesity calculated from self-reported data were approximately $10 \%$ lower than estimates based upon directly measured data. ${ }^{160}$

The prevalence of overweight and obesity in the current study was higher than those of the 1978/79 CHS. Our results were consistent with the commonly observed increase in overweight and obesity in Canada's children; ${ }^{57,58}$ however the prevalences found in our study were not as marked as the results from previous studies. Although the 
time of data collection was close between the current study and the 2004 CCHS, the overweight/obesity rate in the 2004 CCHS was much higher. The reason for this difference could be due to differences in the collection method (our study had selfreported data whereas CCHS had measured data), or the actual overweight/obesity rates nationally compared to in one city. ${ }^{161-163}$

Another reason that we observed lower overweight/obesity rates could be due to subject selection bias. Students who participated in the in motion research could have self-selected to participate in the study based on their actual or perceived weight levels. That is, students who either were actually overweight/obese or perceived as such would have not elected to participate in a study that measured these factors. ${ }^{57,164}$

It is important to acknowledge the context in which this study was conducted in Saskatoon, which would have some bearing on the type of results that were found. This thesis used data collected as part of the Saskatoon's in motion research. The vision of this program is to make Saskatoon and region the healthiest community in Canada through physical activity. ${ }^{165}$ This program further envisions that Saskatoon will serve as a model for provincial, national and international initiatives on taking a population based approach to physical activity enhancement. ${ }^{165}$ In 1999, in motion was launched in the Saskatoon Health Region. From 2000 to 2006, the number of people in Saskatoon and region who are active has increased by $39 \% .{ }^{165}$ At present, 124 Saskatoon schools have declared themselves in motion. Each school has a goal to improve physical activity levels by having children engage in 30 minutes of activity every day. ${ }^{165}$ These achievements could in part explain the results that were found in this study. That is, there is a high degree of awareness among Saskatoon adults and youth about the benefits of physical 
activity, which in turn may have led to a lower prevalence of overweight and obesity among adolescents in the current study sample compared to results of the Canada-wide 2004 CCHS.

\section{Trends in BMI and physical activity with age}

In general, the mean BMI for both boys and girls 12-14 years of age in the current study were lower than two older age groups. However there are no discernible differences in mean BMI between 15-16 and 17-18 year-old groups for both girls and

boys at both time points. This trend was consistent with the results of a previous study. ${ }^{166}$ The results of the current investigation also provided further evidence that the level of physical activity declined with age in both boys and girls. This trend was similar to the results from previous studies. ${ }^{65,67,72,75,167-171}$ There seem to be increasing evidence to show that physical activity decreases as adolescents age and that this in turn, at least in part, may cause increased overweight/obesity observed among adolescents.

\section{Patterns of change in overweight/obesity and physical activity}

The proportion of adolescent girls who were overweight or obese increased over time. This trend was consistent with the observed trend which saw physical activity levels among girls decreasing over time. Among adolescent boys, however, the pattern of change observed in overweight/obesity and physical activity levels were not depended on each other. Boys who were highly physically active decreased in all three adolescent age groups, while the boys who were overweight/obese increased only in 12-14 year-old boys. 
In the current study, sex differences in physical activity in the same age groups were a consistent finding. Adolescent girls were significantly less active than boys. This finding confirmed the results from several investigations using self-reported measures of physical activity. ${ }^{72,77,170-175}$ This suggests that physical activity among adolescent girls usually decreases over time and that, in turn, it results in an increase in overweight/obesity among girls over time. In boys, however, while physical activity decreased over time, similar to in girls, it did not necessarily result in an increase in overweight/obesity. This finding confirms the findings from previous studies ${ }^{67,78}$ that maturation has an effect on the differences in physical activity participation between boys and girls of similar chronological age.

\section{Implications for interventions}

This study has implications for health promotion efforts aimed at reducing sex disparities in physical activity. Since adolescent girls were less likely to be active than boys, a high priority should be placed on developing effective interventions for adolescent girls.

According to studies, the age between 13 and 18 years is the period of greatest decline in physical activity levels for both males and females. ${ }^{66,69-71}$ This finding is consistent with the current finding that levels of physical activity declined with age in both adolescent boys and girls. It is, therefore, especially necessary to target interventions to this age group to counter this decline. A variety of strategies may need to be considered, from those that directly appeal to adolescents, to increasing parental 
activities to promoting physical amenities and building publicly accessible facilities for physical activity.

Although, the decline in physical activity levels with age among adolescents is well documented in many studies, ${ }^{66,67,69-71}$ and it is confirmed again in this study, this phenomenon is still not well understood. The mechanism of the decline was not well identified. Therefore, more research is needed to improve understanding about the reasons and mechanism for decline.

\subsection{Determinants of Changing Physical Activity Patterns}

What are the effects of family/friends and physical activity environments on the changing patterns of physical activity in this sample?

\subsubsection{Effects of Family and Friends}

The results confirmed the hypothesis that family had influence on determining physical activity patterns in adolescents over time, but this study does not support the assertion that friends had an affect on adolescent physical activity. In the final model friend's support did not remain as a significant variable in predicting adolescent physical activity over time.

The support from family was found to be a significant predictor of adolescent physical activity. The associations were significantly positive for family's direct support and significantly negative for family's indirect support. Adolescents who received greater direct support from family members (such as encouraging adolescents to stick with physical activity, paying for physical activity programs, watching adolescents doing physical activity and saying they were good at physical activity) were more likely to 
sustain their physical activity levels. This finding is consistent with previous studies. The studies of Biddle and McGuire et al. found that parental encouragement had been shown to increase children's physical activity level. ${ }^{176-178}$ Also, parental facilitation of physical activity (which include such activity as transporting the child to physical activity venues, providing equipment or opportunities to be active) has been strongly correlated with children's physical activity level. ${ }^{179-181}$

Interestingly, the family's indirect support was associated with physical activity in the opposite direction to what was expected. The more the family's indirect support the less sustaining the adolescents' physical activity. Family's indirect support included activity such as role modeling (seen to be participating physical activity), saying physical activity was good and fun, offering to be physically active with adolescents, and teaching physical activity skills. There is some support in the literature that role modeling was not as a major source of parental influence on physical activity in children as one would think. ${ }^{179}$ With increasing desire for independence and autonomy adolescents may be less influenced by their parents. Increasingly as adolescents mature they spend more time with their friends, away from family contact. It is plausible that some of the behaviour that was named as 'indirect support,' such as role modeling of physical activity by family, did not had the positive influence on sustaining physical activity.

Although not significant in the final model in this study, the friend's support was significant positive influence on physical activity at the bivariate level. The results in the multivariable model in this study is contrary to findings in other studies, ${ }^{28,29,84,182,183}$ which found that friend's support was a dominant influence on physical activity. The results from this study supports the notion that support from friends' had an influence on 
sustaining physical activity among adolescents, but that this association was eclipsed by the direct support that adolescents received from their family. In other words, family's direct support were more influential than friends' support to sustaining physical activity in this sample. These results may be important to consider for intervention development to promote physical activity.

\subsubsection{Effects of Environments}

According to King et al., Sallis and Owen, physical environments have the capacity to facilitate or hinder physical activity. ${ }^{184,185}$ Ecological models of behavior led investigators to hypothesize that aspects of the physical environment can influence participation in physical activity. ${ }^{186}$ The present study examined the effects of home and neighborhood environments on the adolescent's participation in physical activity. The findings revealed that home environment had a positive impact on adolescent physical activity, and that neighborhood had no impact on physical activity in adolescents. These findings are consistent with an interpretation that the home environments that are 'rich' in resources relevant for physical activity might have a greater influence on adolescents' physical active levels than living in certain neighbourhoods. Although the correlation between home environment and physical activity was not strong, it still could be concluded that home environment was a influential determinant of sustaining adolescent physical activity. This result was similar to finding in the Sallis et al. study ${ }^{186}$ that home environment were positively correlated with self-reported physical activity among college students. 


\subsubsection{Implications for Physical Activity Intervention}

The current study results clearly establish that encouragement and involvement of family in physical activity predicted high physical activity levels among adolescents. Implication for these findings is that family members should be encouraged to participate in physical activity with adolescents. Because most children remain in the family environment for a long time, family-based physical activity intervention programs hold promise for long-term effectiveness. Therefore, the community actions should acknowledge the potential of families as physical activity promoting units, and the vital contributions of families to physical activity. Health promotion programs aimed at stimulating daily physical activity of families and the reduction of sedentary activities are very promising.

Direct help from parents, such as organizing outdoor exercise activities is positively related to physical activity among children and adolescents. ${ }^{34}$ Parents should be encouraged to be physical activity role models for their children and support their children's participation in enjoyable physical activities. Adolescents should be encouraged to participate in physical activity or family activities that may be helpful to reduce the amount of sedentary time (e.g. they can be asked to contribute to house chores or encouraged to ride their bicycles or walk for short distances). The goal is to increase the amount of time spent doing physical activity or other outdoor activities while decreasing the amount of sedentary behaviors such as watching television and playing computer games. ${ }^{91}$

A reduction of childhood sedentary activities should also be promoted. Such an intervention would require cooperation between the family, schools, neighbourhood 
associations and strong parental commitment to behavioral change and provision of alternative leisure activities. These types of interventions could also be incorporated into positive parenting strategies and early childhood education. Parents should be encouraged to limit access to their children's sedentary activities such as TV watching, gaming from a very young age.

Another aspect of the family environment that could be a focus for intervention is the physical material and equipment available in households. Households should provide safe spaces and facilities for physical activity that encourage and enable adolescents and all family members to participate in and enjoy physical activities. These spaces and facilities should be available for adolescents to access all time of the year and should meet recommendation safety standards for design, and installation.

\subsection{Methodological Issues: Strengths and Limitations}

The study design and methodology have both strengths and limitations which may affect the study results. The main advantages and disadvantages are identified below.

\subsubsection{Study Limitations}

The present study had several methodological limitations. First, the use of selfreports for measures of physical activity, heights, weights and other behaviors in this study may have introduced some bias in reporting. Studies have found that among adolescents self-reported values of physical activity, ${ }^{187}$ weight and height ${ }^{188,189}$ tend to be biased in opposite directions. Adolescent respondents tend to overestimate their physical activity, underestimate their weight and exaggerate their height. Therefore, in the current study, the level of physical activity may be over-reported, and the prevalence 
of overweight and obesity may be underestimated. This could result in a further reduction in the estimation of the associations between physical activity and overweight and obesity, if self-reported data continue to be used for overweight and obesity surveillance. ${ }^{190}$ Other studies have implied that self-reported measure was subject to considerable recall bias and have limited validity and reliability among children. ${ }^{7,191}$ Future studies should use both self-reported and objective measures to reduce potential errors associated with relying on self-reported data; ${ }^{131}$ this would likely increase the validity of findings. ${ }^{192}$

Second, the current study recruited volunteers via informed consent. It is difficult to overcome the self-selection process that occurs among those who consent to participate versus those who do not. The present study could have been subjected to a selection bias, because the adolescents who would have agreed to undergo physical activity testing may have been the same individuals who are physically active rather than individuals who were physically inactive or carry excess weight. The study population, therefore, could be biased toward physically active adolescents in Saskatoon.

Third, the intervals between data collection points for physical activity were short (only a month), this make the study did not fully reflect the variation of physical activity levels of adolescents over time. In addition, the data on 'Factors Affecting My Physical Activity' were available in only two time points versus five time points on physical activity data. Therefore, the close relationship between overweight/obesity and physical activity in this study was not clearly revealed. 
Finally, although it should be acknowledged the advantages of longitudinal analysis, this study design is resource intensive in terms of time and money for both investigators and participants.

\subsubsection{Study Strengths}

The study also has a number of important methodological strengths. First, longitudinal study is the best design to investigate causal relationship between potential predictor variables and level of physical activity participation and to gain a better understanding of the complexities between variables that may promote or limit physical activity among youth.

Second, the energy expenditure level of greater than 8 KKD has been suggested as the cut point in which youth and adolescents will achieve health benefits. This

conservative cut point has been used to account for potential errors in over-reporting that may occur in self-reporting of physical activity. 


\section{CONCLUSION}

This thesis has provided information concerning overweight/obesity status and physical activity among adolescents in Saskatoon. The longitudinal study design was an appropriate method to investigate the association and causal relationship between predictor variables and level of physical activity participation among adolescents. The study results are credible due to the excellent response rate and relatively large sample size. The followings were main findings identified in the current study:

- The prevalence of overweight and obesity, when measured twice over a relatively short period of time, remained higher for boys than for girls. Specifically, the prevalence of overweight was $17.1 \%$ for boys and $9.7 \%$ for girls at Time 1 , and the corresponding numbers for obesity were $5.9 \%$ for boys and 3.8\% for girls. At Time 3, the prevalence of overweight was $15.3 \%$ for boys and 10.2 for girls; prevalence of obesity was $5.2 \%$ for boys and $4.7 \%$ for girls.

- Among adolescent girls, the proportion of overweight and obesity increased over time, while the proportion of overweight and obesity was not discernible for boys.

- The BMI increased with age, while physical activity decreased with age for both boys and girls; however adolescent boys were more likely to be physically active than adolescent girls.

- Adolescents who received greater direct support from family members were more likely to sustain their physical activity levels, while the more the family's indirect support the less sustaining the adolescents' physical activity. Although the support from friends' had an influence on sustaining physical activity among adolescents, 
in this study, this association was eclipsed by the direct support that adolescents received from their family.

- Home environments that are 'rich' in physical resources relevant for physical activity might have a greater influence on adolescents' sustained physical activity levels than living in certain neighbourhoods.

The current investigation confirms findings from previous studies that adolescent BMI increase with age, while physical activity decreased with age and boys were more likely to be active than girls. The results from this study also confirm previous findings that direct support from family and home environment had influence on sustaining physical activity among adolescents. Contrary to some other studies, indirect support from family was contributed to decrease adolescents' physical activity, and no association between friend's support, neighborhood environment and adolescent physical activity were found in this study.

Although the results of the current study might have brought about important implications in developing intervention to promote physical activity among adolescents, I also would suggest that further research should be carried out on the relationship between adolescents' physical activity and age, sex; and the influence of friend's support, home environment and neighbourhood to physical activity patterns in adolescents. Then the results would provide more evidences to support for intervention strategies to encourage physical activity. Moreover, more studies using both self-reported and objective measures of physical activity level should be conducted to produce results with minimal potential errors that associated with relying on self-reported data. 


\section{REFERENCES}

1. World Health Organization. Global Strategy on Diet, Physical Activity and Health. 2003.

2. National Population Health Survey, 1994-1995. Ottawa: Statistics Canada;. 1995.

3. Belanger-Ducharme F, Tremblay A. Prevalence of obesity in Canada. Obes Rev. 2005 Aug;6(3):183-6.

4. Statistics Canada. Canadian Community Health Survey: Obesity among children and adults. 2005 [cited 2006 Jan 18th]; Available from: http://www.statcan.ca/Daily/English/050706/td050706.htm

5. Campbell K, Waters E, O'Meara S, Kelly S, Summerbell C. Interventions for preventing obesity in children. Cochrane Database Syst Rev. 2002(2):CD001871.

6. Dietz WH. Childhood weight affect adult morbidity and mortality. J Nutr. 1998;128(2 Suppl):411S-4S.

7. O'Loughlin J, Gray-Donald K, Paradis G, Meshefedjian G. One- and two-year predictors of excess weight gain among elementary schoolchildren in multiethnic, lowincome, inner-city neighborhoods. Am J Epidemiol. 2000 Oct 15;152(8):739-46.

8. Nammi S, Koka S, Chinnala KM, Boini KM. Obesity: an overview on its current perspectives and treatment options. Nutr J. 2004 Apr 14;3:3.

9. Bouchard C, Perusse L, Leblanc C, Tremblay A, Theriault G. Inheritance of the amount and distribution of human body fat. Int J Obes. 1988;12(3):205-15.

10. Rosenbaum M, Leibel RL. The physiology of body weight regulation: relevance to the etiology of obesity in children. Pediatrics. 1998;101 (Suppl):525-39.

11. Hill JO, Trowbridge FL. Childhood obesity: future directions and research priorities. Pediatrics. 1998 Mar;101(3 Pt 2):570-4.

12. Hill JO, Peters JC. Environmental contributions to the obesity epidemic. Science. 1998;280:1371-4.

13. Anderson R, Crespo C, Bartlett S, Cheskin L, Pratt M. Relationship of physical activity and television watching with body weight and level of fatness among children: results from the Third National Health and Nutrition Examination Survey. JAMA 1998;279(12):938-59.

14. Sothern MS. Obesity prevention in children: physical activity and nutrition. Nutrition. 2004 Jul-Aug;20(7-8):704-8.

15. McGloin AF, Livingstone MBE, Greene LC, Webb SE, Givson JM, Jebb SA, et al. Energy and fat intake in obese and lean children at varying risk of obesity. International Journal of Obesity. 2002;26:200-7.

16. Rodriguez-Altalego F, Garces C, Gorgojo L, Lopez Garcia E, Martin-Moreno J, Benavente M, et al. Dietary patterns among children aged 6-7 year in four Spanish cities with widely differing cardiorvascular mortality. European Journal of Clinical Nutrition. 2002;56(2):141-8.

17. Lyznicki JM, Young DC, Riggs JA, Davis RM. Obesity: assessment and management in primary care. Am Fam Physician. 2001 Jun 1;63(11):2185-96.

18. Troiano RP, Flegal KM, Kuczmarski RJ, Campbell SM, Johnson CL. Overweight prevalence and trends for children and adolescents. The National Health and Nutrition Examination Surveys, 1963 to 1991. Arch Pediatr Adolesc Med. 1995 Oct;149(10):108591. 
19. Graf C, Koch B, Kretschmann-Kandel E, Falkowski G, Christ H, Coburger S, et al. Correlation between BMI, leisure habits and motor abilities in childhood (CHILTProject). Int J Obes Relat Metab Disord. 2004;28(1):22-6.

20. World Health Organization. Obesity: Preventing and Managing the Global Epidemic. WHO technical report series no.894. Geneva: World Health Organization,. 2000.

21. Robinson TN, Sirard JR. Preventing childhood obesity: a solution-oriented research paradigm. Am J Prev Med. 2005 Feb;28(2 Suppl 2):194-201.

22. Raine Kim. Overweight and Obesity in Canada: A Population Health Perspective. Canadian Population Health Initiative. August 2004.

23. Anderssen N, Wold B. Parental and peer influences on leisure-time physical activity in young adolescents. Res Q Exerc Sport. 1992 Dec;63(4):341-8.

24. Maffeis C, Talamini G, Tato L. Influence of diet, physical activity and parents' obesity on children's adiposity: a four-year longitudinal study. Int J Obes Relat Metab Disord. 1998 Aug;22(8):758-64.

25. Burke V, Beilin LJ, Dunbar D. Family lifestyle and parental body mass index as predictors of body mass index in Australian children: a longitudinal study. Int J Obes Relat Metab Disord. 2001 Feb;25(2):147-57.

26. Fogelholm M, Nuutinen O, Pasanen M, Myohanen E, Saatela T. Parent-child relationship of physical activity patterns and obesity. Int J Obes Relat Metab Disord. 1999 Dec;23(12):1262-8.

27. Butcher J. Socialization of adolescent girls into physical activity. Adolescence. $1983 ; 18(72): 753-66$.

28. Greendorfer SL, Lewko JH. Role of family members in sport socialization of children. Res Q. 1978 May;49(2):146-52.

29. Gottlieb NH, Chen M-S. Sociocultural correlates of childhood sporting activities: their implications for heart health. Soc Sci Med. 1985;21(5):533-9.

30. Kelly LA, Reilly JJ, Fisher A, Montgomery C, Williamson A, McColl JH, et al. Effect of socioeconomic status on objectively measured physical activity. Arch Dis Child. 2006 Jan;91(1):35-8.

31. Sallis JF, Glanz K. The role of built environments in physical activity, eating, and obesity in childhood. Future Child. 2006 Spring;16(1):89-108.

32. Lindsay AC, Sussner KM, Kim J, Gortmaker S. The role of parents in preventing childhood obesity. Future Child. 2006 Spring;16(1):169-86.

33. Katzmarzyk PT. Pediatric Obesity Symposium \& Workshop. April 24th, 2006; College of Kinesiology - University of Saskatchewan; April 24th, 2006.

34. United States Department of Health and Human Services. Physical activity and Health. A report of the Surgeon General. US Department of Health and Human Services, Centers for Disease Control and Prevention. 1996.

35. Cameron C, Craig CL, Paolin S. Local opportunities for physical activity and sport: Trends from 1999 - 2004. Ottawa, ON. Canadian Fitness and Lifestyle Research Institute. 2005.

36. Corbin C, Pangrazi RP, Welk GJ. Toward an understanding of appropriate physical activity levels for youth. Physical Activity and Fitness Research Digest. 1994;Series 1(No. 8). 
37. Brenner ND, Billy JOG, Grady WR. Assessment of factors affecting the validity of self-reported health-risk behavior among adolescents: Evidence from the scientific literature. J Adolesc Health. 2003;33(6):436-57.

38. Craig C, Russell S, Cameron C, Beaulieu A. Foundation for joint action:

Reducing physical inactivity. Ottawa, ON: Canadian Fitness and Lifestyle Research Institute; 1999.

39. Katzmarzyk PT, Gledhill N, Shephard RJ. The economic burden of physical inactivity in Canada. Cmaj. 2000 Nov 28;163(11):1435-40.

40. Varo JJ, Martinez-Gonzalez MA, De Irala-Estevez J, Kearney J, Gibney M, Martinez JA. Distribution and determinants of sedentary lifestyles in the European Union. Int J Epidemiol. 2003 Feb;32(1):138-46.

41. Blair SN, Kohl HW, 3rd, Paffenbarger RS, Jr., Clark DG, Cooper KH, Gibbons

LW. Physical fitness and all-cause mortality. A prospective study of healthy men and women. Jama. 1989 Nov 3;262(17):2395-401.

42. World Health Organization. Global Strategy on Diet, Physical Activity and Health. 2007.

43. WHO/CDC Collaborating Center on Physical Activity and Health Promotion. Atlanta. 2000.

44. Pratt M, Macera C, Wang G. Higher Direct Medical Costs Associated With Physical Inactivity. The Physician and Sportsmedicine. 2000;28(10):63.

45. Katzmarzyk PT, Janssen I. The economic costs associated with physical inactivity and obesity in Canada: an update. Can J Appl Physiol. 2004 Feb;29(1):90-115.

46. Department of Health and Human Services - Centers for Disease Control and Prevention. Overweight and Obesity: An Overview. 2007 May, 22 [cited 2007 June, 20]; Available from: http://www.cdc.gov/nccdphp/dnpa/obesity/contributing factors.htm 47. U.S. Department of Health \& Human Services - National Institutes of Health Disease and Conditions Index. What Are Overweight and Obesity? 2007 [cited 2007 October 5th]; Available from: http://www.nhlbi.nih.gov/health/dci/Diseases/obe/obe_whatare.html 48. Myers MD. Objective Medical Information on Obesity, Weight Management, Eating Disorders, and Related Topics: Definition of obesity. 2004 [cited 2007 Sep. 30]; Available from: http://www.weight.com/definition.asp

49. World Health Organization. Physical status: the use and interpretation of anthropometry. Geneva: World Health Organization. 1995.

50. Quetelet A. Physique sociale: ou, essai sur le développement des facultés de l'homme. Brussels: C Muquardt. 1869.

51. Abrantes MM, Lamounier JA, Colosimo EA. Recommendations for the use of body mass index for the classification of overweight and obese children and adolescents. Food Nutr Bull. 2002;23(3):262-6.

52. Franklin MF. Comparison of weight and height relations in boys from 4 countries. Am J Clin Nutr. 1999 Jul;70(1):157S-62S.

53. Bellizzi MC, Dietz WH. Workshop on childhood obesity: summary of the discussion. Am J Clin Nutr. 1999 Jul;70(1 Part 2):173S-5S.

54. Cole TJ, Bellizzi MC, Flegal KM, Dietz WH. Establishing a standard definition for child overweight and obesity worldwide: international survey. Bmj. 2000 May 6;320(7244):1240-3. 
55. Disordered-eating. Limitations of Body Max Index (BMI). 2008 [cited 2008

April 2nd]; Available from: http://www.disordered-eating.co.uk/signs-of-eatingdisorders/body-mass-index-limitations.html

56. World Health Organization. Obesity: preventing and managing the global epidemic. Report of a WHO consultation on Obesity. World Health Organization Technical Report Series. 2000;894:i-xii, 1-253.

57. Tremblay MS, Katzmarzyk PT, Willms JD. Temporal trends in overweight and obesity in Canada, 1981-1996. Int J Obes Relat Metab Disord. 2002 Apr;26(4):538-43. 58. Tremblay MS, Willms JD. Secular trends in the body mass index of Canadian children. Cmaj. 2000 Nov 28;163(11):1429-33.

59. Willms JD, Tremblay MS, Katzmarzyk PT. Geographic and demographic variation in the prevalence of overweight Canadian children. Obes Res. 2003 May;11(5):668-73.

60. Statistics Canada. National Longitudinal Survey of Children and Youth (NLSCY) 1994-1999. Statistics Canada and Social Development Canada (SDC).

61. Birmingham CL, Muller JL, Palepu A, Spinelli JJ, Anis AH. The cost of obesity in Canada. Cmaj. 1999 Feb 23;160(4):483-8.

62. Spence JC, Lee RE. Toward a comprehensive model of physical activity. Psychology of Sport and Exercise. 2003;4:7-24.

63. United States Government Accountability Office. GAO Congressional Briefing: Childhood obesity: Factors Affecting Physical Activity; 2006.

64. Sallis JF. Epidemiology of physical activity and fitness in children and adolescents. Crit Rev Food Sci Nutr. 1993;33(4-5):403-8.

65. Trost SG, Pate RR, Sallis JF, Freedson PS, Taylor WC, Dowda M, et al. Age and gender differences in objectively measured physical activity in youth. Med Sci Sports Exerc. $2002 \mathrm{Feb} ; 34(2): 350-5$.

66. Sallis JF. Age-related decline in physical activity: a synthesis of human and animal studies. Med Sci Sports Exerc. 2000 Sep;32(9):1598-600.

67. Sherar LB, Esliger DW, Baxter-Jones AD, Tremblay MS. Age and gender differences in youth physical activity: does physical maturity matter? Med Sci Sports Exerc. 2007 May;39(5):830-5.

68. Sallis JF, Prochaska JJ, Taylor WC. A review of correlates of physical activity of children and adolescents. Med Sci Sports Exerc. 2000 May;32(5):963-75.

69. Caspersen CJ, Pereira MA, Curran KM. Changes in physical activity patterns in the United States, by sex and cross-sectional age. Med Sci Sports Exerc. 2000 Sep;32(9):1601-9.

70. Telama R, Yang X. Decline of physical activity from youth to young adulthood in Finland. Med Sci Sports Exerc. 2000 Sep;32(9):1617-22.

71. van Mechelen W, Twisk JW, Post GB, Snel J, Kemper HC. Physical activity of young people: the Amsterdam Longitudinal Growth and Health Study. Med Sci Sports Exerc. 2000 Sep;32(9):1610-6.

72. Van Mechelen W, Kemper HC. Habitual physical activity in longitudinal perspective. In: the Amsterdam Growth Study, HCGKemper (Ed) Champaign, IL: Human Kinetics,. 1995:135-58.

73. Caspersen CJ, Merritt RK. Physical activity trends among 26 states, 1986-1990. Med Sci Sports Exerc. 1995;27(5):713-20. 
74. Jago R, Anderson CB, Baranowski T, Watson K. Adolescent patterns of physical activity differences by gender, day, and time of day. Am J Prev Med. 2005

Jun;28(5):447-52.

75. Kimm SY, Glynn NW, Kriska AM, Fitzgerald SL, Aaron DJ, Similo SL, et al. Longitudinal changes in physical activity in a biracial cohort during adolescence. Med Sci Sports Exerc. 2000 Aug;32(8):1445-54.

76. Riddoch CJ, Bo Andersen L, Wedderkopp N, Harro M, Klasson-Heggebo L, Sardinha LB, et al. Physical activity levels and patterns of 9- and 15-yr-old European children. Med Sci Sports Exerc. 2004 Jan;36(1):86-92.

77. Sallis JF, Alcaraz JE, McKenzie TL, Hovell MF. Predictors of change in children's physical activity over 20 months. Variations by gender and level of adiposity. Am J Prev Med. 1999 Apr;16(3):222-9.

78. Thompson AM, Baxter-Jones AD, Mirwald RL, Bailey DA. Comparison of physical activity in male and female children: does maturation matter? Med Sci Sports Exerc. 2003;35(10):1684-90.

79. Malina RM, Bouchard C, Bar-Or O. Growth, Maturation, and Physical Activity. Champaign, IL: Human Kinetics. 2004:307-33.

80. Mirwald RL, Baxter-Jones AD, Bailey DA, Beunen GP. An assessment of

maturity from anthropometric measurements. Med Sci Sports Exerc. 2002 Apr;34(4):68994.

81. College of Kinesiology - University of Saskatchewan. Prediction of Age of Peak Height Velogicy. 2008 [cited 2008 3rd April]; Available from: http://athena.usask.ca/growthutility/phv ui.cfm?type=1

82. Janz NK, Becker MH. The Health Belief Model: a decade later. Health Educ Q. 1984 Spring; 11(1):1-47.

83. Glanz K, Marcus Lewis F, Rimer BK. Theory at a Glance: A Guide for Health Promotion Practice. National Institute of Health. 1997.

84. Ferguson K, Yeslais C, Pohmrehn P, Kirkpartick M. Attitudes, knowledge, and beliefs as predictors of exercise intentions and behavior in schoolchildren. J Sch Health. 1989;59(3):112-5.

85. DiLorenzo TM., Stucky-Ropp RC., Vander Wal JS., Gotham HJ. Determinants of Exercise among Children. II. A Longitudinal Analysis. Preventive Medicine. 1998;27:470-7.

86. Katzmarzyk PT, Perusse L, Rao DC, Bouchard C. Familial risk of obesity and central adipose tissue distribution in the general Canadian population. Am J Epidemiol. 1999 May 15;149(10):933-42.

87. Hill JO, Wyatt HR, Melanson EL. Genetic and environmental contributions to obesity. Med Clin North Am. 2000 Mar;84(2):333-46.

88. Dehghan M, Akhtar-Danesh N, Merchant AT. Childhood obesity, prevalence and prevention. PubMed Central Journal List - Nutrition Journal. 2005 Sep 2;4(1):24.

89. Hill JO. Physical activity and obesity. Lancet. 2004 Jan 17;363(9404):182.

90. Goran MI, Treuth MS. Energy expenditure, physical activity, and obesity in children. Pediatr Clin North Am. 2001 Aug;48(4):931-53.

91. Amisola RV, Jacobson MS. Physical activity, exercise, and sedentary activity: relationship to the causes and treatment of obesity. Adolesc Med. 2003 Feb;14(1):23-35. 
92. LeBlanc CM. The growing epidemic of child and youth obesity--another twist? Can J Public Health. 2003 Sep-Oct;94(5):329-31.

93. Boynton-Jarrett R, Thomas TN, Peterson KE, Wiecha J, Sobol AM, Gortmaker SL. Impact of television viewing patterns on fruit and vegetable consumption among adolescents. Pediatrics. 2003 Dec;112(6 Pt 1):1321-6.

94. Hall KD, Stephen AM, Reeder BA, Muhajarine N, Lasiuk G. Diet, obesity and education in three age groups of Saskatchewan women. Can J Diet Pract Res. 2003 Winter;64(4):181-8.

95. Health Canada. Young people in Canada: their health and well-being. Health Behaviour in School-Aged Children. 1990.

96. Gordon-Larsen P, McMurray RG, Popkin BM. Determinants of adolescent physical activity and inactivity patterns. Pediatrics. 2000 Jun;105(6):E83.

97. Janssen I, Boyce WF, Simpson K, Pickett W. Influence of individual- and arealevel measures of socioeconomic status on obesity, unhealthy eating, and physical inactivity in Canadian adolescents. Am J Clin Nutr. 2006 Jan;83(1):139-45.

98. Duncan C, Jones K, Moon G. Do place matter? A multi-level analysis of regional variations in health-related behaviour in Britain. Social Science \& Medicine. 1993;37:725-33.

99. Duncan C, Jones K, Moon G. Health-related behaviour in context: A multilevel modelling approach. Social Science \& Medicine. 1996;42:817-30.

100. Gauvin L, Richard L, Potvin L, Craig C, Spence J, Quinney H, et al. Public infrastructrue, policies, and practices for the promotion of physical activity in Canada. Ottawa, Ontario: NHRDP Grant \# R6605-5241-004 Final Report; 2001b.

101. Canadian Fitness and Lifestyle Research Institute. Sedentary living hazardous to health. Progress in Prevention. 1997;Bulletin no. 20.

102. Gauvin L, Interdisciplinary Research Group on Health. Social Disparities and Involvement in Physical Activity: Shaping the Policy Agenda in Healthy Living to Successfully Influence Population Health. 2003.

103. Walcott-McQuigg JA, Zerwic JJ, Dan A, Kelley MA. An ecological approach to physical activity in African American women. Medscape Womens Health. 2001 Dec;6(6):3.

104. Oliver LN, Hayes MV. Neighbourhood socio-economic status and the prevalence of overweight Canadian children and youth. Can J Public Health. 2005 NovDec;96(6):415-20.

105. Molnar BE, Gortmaker SL, Bull FC, Buka SL. Unsafe to play? Neighborhood disorder and lack of safety predict reduced physical activity among urban children and adolescents. Am J Health Promot. 2004 May-Jun;18(5):378-86.

106. Bruce MJ, Katzmarzyk PT. Canadian population trends in leisure-time physical activity levels, 1981-1998. Can J Appl Physiol. 2002 Dec;27(6):681-90.

107. Statistics Canada. National Longitudinal Survey of Children and Youth (NLSCY): Childhood Obesity, 1994-1999. The Daily (October 18, 2002).

108. Cecil JE, Watt P, Murrie IS, Wrieden W, Wallis DJ, Hetherington MM, et al. Childhood obesity and socioeconomic status: a novel role for height growth limitation. Int J Obes (Lond). 2005 Oct;29(10):1199-203.

109. Dietz WH. The role of lifestyle in health: the epidemiology and consequences of inactivity. Proc Nutr Soc. 1996 Nov;55(3):829-40. 
110. Australians Bureau of Statistics. How Australians use their time. Canberra, Australia: Commonwealth Government; 1994. Report No.: 4153.0.

111. Salmon J, Owen N, Crawford D, Bauman A, Sallis JF. Physical activity and sedentary behavior: a population-based study of barriers, enjoyment, and preference. Health Psychol. 2003 Mar;22(2):178-88.

112. Ainsworth BE, Haskell WL, Leon AS, Jacobs DR, Jr., Montoye HJ, Sallis JF, et al. Compendium of physical activities: classification of energy costs of human physical activities. Med Sci Sports Exerc. 1993 Jan;25(1):71-80.

113. Mokdad AH, Marks JS, Stroup DF, Gerberding JL. Actual causes of death in the United States, 2000. Jama. 2004 Mar 10;291(10):1238-45.

114. Pate RR, Pratt M, Blair SN, Haskell WL, Macera CA, Bouchard C, et al. Physical activity and public health. A recommendation from the Centers for Disease Control and Prevention and the American College of Sports Medicine. Jama. 1995 Feb 1;273(5):4027.

115. Kujala UM, Kaprio J, Sarna S, Koskenvuo M. Relationship of leisure-time physical activity and mortality: the Finnish twin cohort. Jama. 1998 Feb 11;279(6):440-4. 116. Bryan S, Walsh P. Physical Activity and Obesity in Canadian Women. BMC Womens Health. 2004 Aug 25;4 Suppl 1:S6.

117. Tremblay MS, Willms JD. Is the Canadian childhood obesity epidemic related to physical inactivity? Int J Obes Relat Metab Disord. 2003 Sep;27(9):1100-5.

118. Statistics Canada. Television Viewing, by Age and Sex, by Provinces: 2003. 2005 November 23rd [cited 2006 Feb 20th]; Available from:

http://www40.statcan.ca/101/cst01/arts23.htm

119. Statistics Canada. Characteristics of household Internet users, by location of access 2005 [cited Feb 20th]; Available from:

http://www40.statcan.ca/101/cst01/comm10a.htm

120. Carriere G. Parent and child factors associated with youth obesity. Health Rep. 2003;14 Suppl:29-39.

121. Dietz WH. Childhood obesity: Susceptibility, cause, and management. Journal of Pediatrics. 1983;103(5).

122. Statistics Canada. Parent and child factors associated with youth obesity. Nov. 2003 [cited 2006 Jan. 22nd]; Available from:

http://www.statcan.ca/Daily/English/031103/d031103a.htm

123. Whitaker RC, Wright JA, Pepe MS, Seidel KD, Dietz WH. Predicting obesity in young adulthood from childhood and parental obesity. N Engl J Med. 1997 Sep 25;337(13):869-73.

124. Locard E, Mamelle N, Billette A, Miginiac M, Munoz F, Rey S. Risk factors of obesity in a five year old population. Parental versus environmental factors. Int J Obes Relat Metab Disord. 1992 Oct;16(10):721-9.

125. Klesges RC, Eck LH, Hanson CL, Haddock CK, Klesges LM. Effects of obesity, social interactions, and physical environment on physical activity in preschoolers. Health Psychol. 1990;9(4):435-49.

126. Sallis JF, Patterson TL, McKenzie TL, Nader PR. Family variables and physical activity in preschool children. J Dev Behav Pediatr. 1988;9:57-61. 
127. Moore LL, Lombardi DA, White MJ, Campbell JL, Oliveria SA, Ellison RC. Influence of parents' physical activity levels on activity levels of young children. J Pediatr. 1991 Feb;118(2):215-9.

128. Davison KK, Cutting TM, Birch LL. Parents' activity-related parenting practices predict girls' physical activity. Med Sci Sports Exerc. 2003 Sep;35(9):1589-95.

129. Freedson PS, Evenson S. Familial aggregation in physical activity. Res Q Exerc Sport. 1991 Dec;62(4):384-9.

130. Yang X, Telama R, Laakso L. Parent's physical activity, socioeconomic status and education as predictors of physical activity and sport among children and youths: a 12 year follow up study. Int Rev Soc Sport. 1996;31:273-94.

131. Sallis JF, Owen N. Physical activity and behavioral medicine: Thousand Oaks. Sage; 1999.

132. Higgins JW, Gaul C, Gibbons S, Gyn GV. Factor influencing physical activity levels among canadian youth. Canadian Journal of Public Health. 2003;94(1):45-51.

133. Okun MA, Karoly P, Lutz R. Clarifying the contribution of subjective norm to predicting leisure-time exercise. Am J Health Behav. 2002 Jul-Aug;26(4):296-305.

134. Sallis JF, Prochaska JJ, Taylor WC, Hill JO, Geraci JC. Correlates of physical activity in a national sample of girls and boys in grades 4 through 12. Health Psychol. 1999;18(4):410-5.

135. Eccles JS. The development of children ages 6 to 14. The Future of Children. 1999;9:30-44.

136. Wold B, Hendry L. Social and environmental factors associated with physical activity in young people. In S. biddle, J. Sallis, \& N. Cavill (Eds.), Young and active? Young people and health-enhancing physical activity--evidence and implications. London: Health Education Authority. 1998:119-32.

137. Prochaska JJ, Rodgers MW, Sallis JF. Association of parent and peer support with adolescent physical activity. Res Q Exerc Sport. 2002 Jun;73(2):206-10.

138. Greendorfer SL, Ewing ME. Race and gender differences in children's socialization into sport. Res Q Exerc Sport. 1981;52:301-10.

139. Klesges RC, Malott JM, Boschee PF, Weber JM. The effects of parental influences on children's food intake, physical activity, and relative weight. Int J Eating Disord. 1986;5:335-46.

140. Sallis JF, Simons-Morton BG, Stone EJ, Corbin CB, Epstein LH, Faucette N, et al. Determinants of physical activity and interventions in youth. Med Sci Sports Exerc. 1992 Jun;24(6 Suppl):S248-57.

141. Sallis JF, Patterson TL, Buono MJ, Atkins CJ, Nader PR. Aggregation of physical activity habits in Mexican-American and Anglo families. J Behav Med. 1988;11:31-41. 142. Garcia AW, Broda MN, Frenn M, Covial C, Pender NJ, Ronis DL. Gender and developmental differences in exercise beliefs among youth and prediction of their exercise behavior. J Sch Health. 1995;65(6):213-19.

143. Tergerson JL, King KA. Do Perceived Cues, Benefits, and Barriers to Physical Activity Differ Between Male and Female Adolescents? Journal of School Health. 2002;72(9):374-80.

144. Baranowski T, Thompson WO, DuRant RH, Baranowski J, Puhl J. Observations on physical activity in physical locations: age, gender, ethnicity, and month effects. Res Q Exerc Sport. 1993 Jun;64(2):127-33. 
145. Strauss RS, Knight J. Influence of the home environment on the development of obesity in children. Pediatrics. 1999 Jun;103(6):e85.

146. Robinson TN. Reducing children's television viewing to prevent obesity: a randomized controlled trial. Jama. 1999 Oct 27;282(16):1561-7.

147. Dietz WH, Gortmaker SL. Do We Fatten Our Children at the Television Set? Obesity and Television Viewing in Children and Adolescents . PEDIATRICS. 1985;75(5):807-12.

148. Romero AJ, Robinson TN, Kraemer HC, Erickson SJ, Haydel KF, Mendoza F, et al. Are perceived neighborhood hazards a barrier to physical activity in children? Arch Pediatr Adolesc Med. 2001 Oct;155(10):1143-8.

149. Army Norton. Children in dangerous neighbourhoods more likely overweight. Reuters Health - Archives of Pediatrics \& Adolescent Medicine 2006.

150. Gordon-Larsen P, Griffiths P, Bentley ME, Ward DS, Kelsey K, Shields K, et al. Barriers to physical activity: qualitative data on caregiver-daughter perceptions and practices. Am J Prev Med. 2004;27:218-23.

151. Handy SL, Boarnet MG, Ewing R, Killingsworth RE. How the built environment affects physical activity: views from urban planning. Am J Prev Med. 2002 Aug;23(2 Suppl):64-73.

152. Resnicow K. School-based obesity prevention. Population versus high-risk interventions. Ann N Y Acad Sci. 1993 Oct 29;699:154-66.

153. Coalition for Active Living, Making the Case for a National Physical Activity Strategy for the Health of Canadians (Ottawa: Coalition for Active Living, 2002). 154. Aaron DJ, Kriska AM, Dearwater SR, Cauley JA, Metz KF, LaPorte RE. Reproducibility and validity of an epidemiologic questionnaire to assess past year physical activity in adolescents. Am J Epidemiol. 1995 Jul 15;142(2):191-201.

155. Sallis J. Self-report measure of children's physical activity. J Sch Health. 1991;61:215-9.

156. Craig CL, Cameron C. Increasing Physical Activity: Assessing trends from 19982003. Ottawa, ON. Canadian Fitness and Lifestyle Research Institute. 2004.

157. Zeger SL, Liang SL. Longitudinal data analysis using generalized linear models. Biometrila,. 1986;73,:13-22.

158. Harville DA. MAximum Likelihood approaches to variance component estimation and to related problems. . Journal of the American Statistical Association,. 1977;72:320-40.

159. Shields M. Measured Obesity Overweight Canadian children and adolescents. Statistics Canada. 2005(1).

160. Cairney J, Wade TJ. Correlates of body weight in the 1994 National Population Health Survey. Int J Obes Relat Metab Disord. 1998 Jun;22(6):584-91.

161. Roberts R. Can self-reported data accurately describe the prevalence of overweight? Public Health. 1995;109(4):275-84.

162. Rowland ML. Reporting bias in height and weight data. Stat Bull Metrop Insur Co. 1989 Apr-Jun;70(2):2-11.

163. Strauss RS. Comparison of measured and self-reported weight and height in a cross-sectional sample of young adolescents. Int J Obes Relat Metab Disord. 1999 Aug;23(8):904-8. 
164. Torrance GM, Hooper MD, Reeder BA. Trends in overweight and obesity among adults in Canada (1970-1992): evidence from national surveys using measured height and weight. Int J Obes Relat Metab Disord. 2002 Jun;26(6):797-804.

165. in motion. in motion - who we are. 2006 [cited 2008 Jan 24th]; Available from: http://www.in-motion.ca/whoweare/

166. Parsons TJ, Manor O, Power C. Physical activity and change in body mass index from adolescence to mid-adulthood in the 1958 British cohort. Int J Epidemiol. 2006 Feb;35(1):197-204.

167. Craig CL, Cameron C, Russell SJ, Beaulieu A. Increasing Physical Activity: Supporting children's physical activity participation. Ottawa, ON. Canadian Fitness and Lifestyle Research Institute. 2001.

168. Craig CL, Cameron C, Russell SJ, Beaulieu A. Increasing Physical Activity: Building supportive recreation and sport system. Ottawa, ON. Canadian Fitness and Lifestyle Research Institute. 2001.

169. Hohepa M, Schofield G, Kolt G. Adolescent obesity and physical inactivity. N Z Med J. 2004 Dec 17;117(1207):U1210.

170. Hovell MF, Sallis JF, Kolody B, McKenzie TL. Children's physical activity choices: a developmental analysis of gender, intensity levels, and time. Pediatr Exerc Sci. 1999;11:158-68.

171. Riddoch C, Savage JM, Murphy N, Cran GW, Boreham C. Long term health implications of fitness and physical activity patterns. Arch Dis Child. 1991 Dec;66(12):1426-33.

172. Cameron C, Craig CL, Stephens T, Ready TA. Increasing Physical Activity: Supporting an active workforce. Ottawa, ON. Canadian Fitness and Lifestyle Research Institute. 2002.

173. Ernst MP, Pangrazi RP. Effects of a physical activity program on children's activity levels and attraction to physical activity. Pediatr Exerc Sci. 1999;11:393-405. 174. Lindquist CH, Reynolds KD, Goran MI. Sociocultural determinants of physical activity among children. Prev Med. 1999;29:305-12.

175. Mota J, Queiros P. Children's behavior: physical activity regarding parents' perception vs. children's activity. Int Rev Soc Sport. 1996;31:173-8.

176. Biddle S, Goudas M. Analysis of children's physical activity and its association with adult encouragement and social cognitive variables. J Sch Health. 1996 Feb;66(2):75-8.

177. McGuire MT, Hannan PJ, Neumark-Sztainer D, Cossrow NH, Story M. Parental correlates of physical activity in a racially/ethnically diverse adolescent sample. J Adolesc Health. 2002 Apr;30(4):253-61.

178. Brustad RJ. Who will go out and play? Parental and psychological influences on children's attraction to physical activity. Pediatric Exercise Science. 1993;5(3):210-23.

179. Welk GJ, Wood K, Morss G. Parental influences on physical activity in children: an exploration of potential mechanisms. Pediatr Exerc Sci. 2003;15:19-33.

180. Sallis JF, Alcaraz JE, McKenzie TL, Hovell MF, Kolody B, Nader PR. Parental behavior in relation to physical activity and fitness in 9-year-old children. Am J Dis Child. 1992 Nov;146(11):1383-8. 
181. Hovell MF, Kolody B, Sallis JF, al. e. Parent support, physical activity, and correlates of adiposity in nine year olds: an exploratory study. J Health Educ. 1996;27(2):126-9.

182. Sallis JF, Hovell MF, Hofstetter CR, Faucher P, Elder JP, Blanchard J, et al. A multivariate study of determinants of vigorous exercise in a community sample. Prev Med. 1989 Jan;18(1):20-34.

183. Brown BA. Factors influencing the process of withdrawal by female adolescents from the role of competitive age group swimmer. Sociology of Sport Journal. 1985;2:111-29.

184. King AC, Jeffery RW, Fridinger F, Dusenbury L, Provence S, Hedlund SA, et al. Environmental and policy approaches to cardiovascular disease prevention through physical activity: Issues and opportunities. Health Educ Q. 1995;22:499-511. 185. Sallis JF, Owen N. Ecological models. In K.Glanz, F.M. Lewis, \& B.K.Rimer (Eds.), Health behavior and health education: Theory, research, and practice (2nd ed.) (pp.403-424). San Francisco: Jossey-Bass. 1997.

186. Sallis J, Johnson M, Calfas K, Caparosa S, Nichols J. Assessing perceived physical environmental variables that may influence physical activity. Research Quarterly for Exercise and Sport. 1997;68(4):345-51.

187. Kriska A. Ethnic and cultural issues in assessing physical activity. Res Q Exerc Sport. 2000 Jun; 71(2 Suppl):S47-53.

188. Fortenberry JD. Reliability of adolescents' reports of height and weight. J Adolesc Health. 1992 Mar;13(2):114-7.

189. Himes JH, Story M. Validity of self-reported weight and stature of American Indian youth. J Adolesc Health. 1992 Mar;13(2):118-20.

190. Katzmarzyk PT. The Canadian obesity epidemic: an historical perspective. Obes Res. 2002 Jul;10(7):666-74.

191. Trost SG, Kerr LM, Ward DS, Pate RR. Physical activity and determinants of physical activity in obese and non-obese children. Int J Obes Relat Metab Disord. 2001 Jun;25(6):822-9.

192. McKenzie TJ, Marshall SJ, Sallis JF, Conway TL. Leisure-time physical activity in school environments: An observational study using SOPLAY. Preventive Medicine. 2000;30:70-7. 


\section{APPENDIXES.}

Appendix A. BMI Values for Overweight and Obesity Proposed by Cole et al. ${ }^{54}$

\begin{tabular}{|c|c|c|c|c|}
\hline \multirow{2}{*}{ Age (year) } & \multicolumn{2}{|c|}{ Overweight } & \multicolumn{2}{c|}{ Obesity } \\
\cline { 2 - 5 } & Boys & Girls & Boys & Girls \\
\hline 6 & 17.55 & 17.34 & 19.78 & 19.65 \\
\hline 7 & 17.92 & 17.75 & 20.63 & 20.51 \\
\hline 8 & 18.44 & 18.35 & 21.60 & 21.57 \\
\hline 9 & 19.10 & 19.07 & 22.77 & 22.81 \\
\hline 10 & 19.84 & 19.86 & 24.00 & 24.11 \\
\hline 11 & 20.55 & 20.74 & 25.10 & 25.42 \\
\hline 12 & 21.22 & 21.68 & 26.02 & 26.67 \\
\hline 13 & 21.91 & 22.58 & 26.84 & 27.76 \\
\hline 14 & 22.62 & 23.34 & 27.63 & 28.57 \\
\hline 15 & 23.29 & 23.94 & 28.30 & 29.11 \\
\hline 16 & 23.9 & 24.37 & 28.88 & 29.43 \\
\hline 17 & 24.46 & 24.70 & 29.41 & 29.69 \\
\hline 18 & 25.00 & 25.00 & 30.00 & 30.00 \\
\hline
\end{tabular}




\section{Appendix B. Physical Activity Questionnaire.}

\section{MY PHYSICAL ACTIVITY}

A. Let's start with Activities That You Sign Up Or Register For: Examples of these kinds of activities may include playing on a school, community or zone team, taking dance or swimming lessons, or attending an exercise class.

1. Circle all of the activities that you participated that in the PAST MONTH that you had to sign up or register for. Do not include time spent in school physical education classes.

$\begin{array}{ll}\text { Aerobics } & \text { Curling } \\ \text { Archery } & \text { Dance } \\ \text { Badminton } & \text { Diving } \\ \text { Baseball } & \text { Figure skating } \\ \text { Basketball } & \text { Football } \\ \text { Bowling } & \text { Gymnastics } \\ \text { Boxing } & \text { Ice hockey } \\ & \text { Kickboxing }\end{array}$

Lacrosse
Martial Arts
Racquetball
Ringette
Rowing
Rugby
Skiing Downhill
Skiing-Cross country

\section{Soccer}

Softbal

Speed Skating

Street/Floor Hockey

Swimming

Syncro

Swimming

Taebo

2. List each activity that you circled above in the "Activity" box below.

3. For each activity, record the number of times you participated each week for the last 4 weeks.

4. For each activity, estimate the average number of minutes that you spent participating each time. Record this in the last box. Only report the time that you were actively participating in the activity.

5. For each activity, record the intensity as Light (light change from normal breathing), Medium (above normal breathing), or Heavy (heavy breathing)

6. For each activity, record where the activity takes place, at School (S), Park (P), or Facility (F).

\begin{tabular}{|c|c|c|c|c|c|c|c|}
\hline \multirow[b]{2}{*}{ ACTIVITY } & \multicolumn{4}{|c|}{$\begin{array}{c}\text { Number of Times Doing the } \\
\text { Activity }\end{array}$} & \multirow{2}{*}{$\begin{array}{l}\text { Average Number of Minutes } \\
\text { You Were Active in the } \\
\text { Activity EACH Time }\end{array}$} & \multirow{2}{*}{$\begin{array}{c}\text { Intensity } \\
\\
\mathrm{L}=\text { Light } \\
\mathrm{M}=\text { =edium } \\
\mathrm{H}=\text { Heavy } \\
\end{array}$} & \multirow{2}{*}{$\begin{array}{c}\text { Location } \\
\text { S= School } \\
\text { P= Park } \\
\text { F= Facility }\end{array}$} \\
\hline & $\begin{array}{c}\text { Week } \\
1 \\
\end{array}$ & $\begin{array}{c}\text { Week } \\
2 \\
\end{array}$ & $\begin{array}{c}\text { Week } \\
3 \\
\end{array}$ & $\begin{array}{c}\text { Week } \\
4 \\
\end{array}$ & & & \\
\hline & & & & & & & \\
\hline & & & & & & & \\
\hline & & & & & & & \\
\hline & & & & & & & \\
\hline
\end{tabular}

**If you did not list any activities in Table 1 (page 1) go to page $3^{* *}$ 
7. During this month, was there any time when you wanted to be physically active, but were not?

Yes No

If yes, please answer the following questions:

a. What activity were you going to do?

b. Why did you not do this activity? (Examples include having the flu, the weather, etc.)

c. If you returned to being active later in the month, did anything help you in your return to being active? (Examples include, I recovered from the flu, I changed activities, I thought about how important it is to be active, the weather, etc.) 
B. Now we would like you to think of all the activities that you participated in the past month that You Did Not Need To

Sign Up Or Register For: Examples of these kinds of activities may include walking, biking, jogging, skateboarding, swimming, or getting together with friends for a basketball game.

1.Circle all of the activities that you participated in the PAST MONTH that you DID NOT have to Sign Up or Register For. Do not include time spent in school physical education classes.

$\begin{array}{llll}\text { Aerobics } & \text { Dance-Break } & \text { Racquetball/Squash } & \text { Skipping } \\ \text { Badminton } & \text { Football } & \text { Ringette } & \text { Snowboarding } \\ \text { Baseball } & \text { Garden/Yard Work } & \text { Rowing } & \text { Soccer } \\ \text { Basketball } & \text { Golf } & \text { Rugby } & \text { Softball } \\ \text { Biking-Outdoors } & \text { Gymnastics } & \text { Running } & \text { Street/Floor hockey } \\ \text { Biking-Stationary } & \text { Hacky-sac } & \text { Shoveling } & \text { Swimming-Diving } \\ \text { Bowling } & \text { Hiking } & \text { Skateboarding } & \text { Swimming-Laps } \\ \text { Boxing } & \text { Horseback Riding } & \text { Skating-Ice } & \text { Swim-Leisure } \\ \text { Curling } & \text { Ice hockey } & \text { Skating-Inline } & \text { Taebo } \\ \text { Dance } & \text { Martial Arts/Kickboxing } & \text { Skiing-Downhill } & \text { Tennis } \\ \text { Dance-Aboriginal } & \text { Ping Pong } & \text { Skiing-Cross Country } & \text { Trampoline }\end{array}$

Ultimate Frisbee
Volleyball
Walking
Wall Climbing
Weight training
Wrestling
Yoga
Other

Skiing-Downhill

Ping Pong Skiing-Cross Country
Tennis

Trampoline

2. List each activity that you circled above in the "Activity" box below.

3. For each activity, record the number of times you participated each week for the last 4 weeks.

4. For each activity, estimate the average number of minutes that you spent participating each time. Only report the time that you were actively participating in the activity.

5. For each activity, record the intensity as Light (light change from normal breathing), Medium (above normal breathing), or Heavy (heavy breathing)

6. For each activity, record where the activity takes place, at Home (H), School (S), Park (P), or Facility (F).

\begin{tabular}{|c|c|c|c|c|c|c|c|}
\hline \multirow[b]{2}{*}{ ACTIVITY } & \multicolumn{4}{|c|}{$\begin{array}{l}\text { Number of Times Doing the } \\
\text { Activity }\end{array}$} & \multirow{2}{*}{$\begin{array}{l}\text { Average Number of Minutes } \\
\text { You Were Active in the } \\
\text { Activity EACH Time }\end{array}$} & \multirow{2}{*}{$\begin{array}{l}\text { Intensity } \\
\mathrm{L}=\text { Light } \\
\mathrm{M}=\text { Medium } \\
\mathrm{H}=\text { Heavy }\end{array}$} & \multirow{2}{*}{$\begin{array}{l}\text { Location } \\
\mathrm{H}=\text { Home } \\
\mathrm{S}=\text { School } \\
\mathrm{P}=\text { Park } \\
\mathrm{F}=\text { Facility }\end{array}$} \\
\hline & $\begin{array}{l}\text { Week } \\
1\end{array}$ & $\begin{array}{l}\text { Week } \\
2\end{array}$ & $\begin{array}{c}\text { Week } \\
3\end{array}$ & $\begin{array}{c}\text { Week } \\
4\end{array}$ & & & \\
\hline & & & & & & & \\
\hline & & & & & & & \\
\hline & & & & & & & \\
\hline
\end{tabular}

**If you did not list any activities in Table 2, you are done. Thank you.** 


\section{During this month, was there any time when you wanted to be physically active, but were not?}

Yes No

If yes, please answer the following questions:

a. What activity were you going to do?

b. Why did you not do this activity? (Examples include having the flu, the weather, etc.)

c. If you returned to being active later in the month, did anything help you in your return to being active? (Examples include, I recovered from the flu, I changed activities, I thought about how important it is to be active, the weather, etc.) 
Appendix C. Physical Activity Determinants Questionnaire.

\title{
Factors Affecting My Physical Activity and Health
}

\begin{abstract}
A. These questions are about your physical activity. The questions below are common reasons that stop people from being physically active. Using the scale, please tell us how confident you are that you could be active if the following things happened.
\end{abstract}

I believe that I can be as active next month as this month even if:

1. I feel tired

$\begin{array}{lllllllllll}0 \% & 10 \% & 20 \% & 30 \% & 40 \% & 50 \% & 60 \% & 70 \% & 80 \% & 90 \% & 100 \%\end{array}$

Not Confident at all Somewhat Confident Confident Very Confident

2. I am in a bad mood

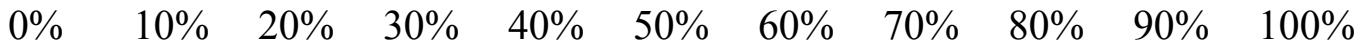

Not Confident at all Somewhat Confident Confident Very Confident

3. I don't have the time

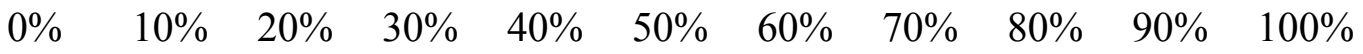

Not Confident at all Somewhat Confident Confident Very Confident

The next questions are about scheduling time for physical activity. Once again, please circle how confident you are regarding the following question.

1. How confident are you that you can arrange your schedule to be active no matter what?

$\begin{array}{lllllllllll}0 \% & 10 \% & 20 \% & 30 \% & 40 \% & 50 \% & 60 \% & 70 \% & 80 \% & 90 \% & 100 \%\end{array}$

Not Confident at all Somewhat Confident Confident Very Confident

2. How confident are you that you can overcome obstacles that prevent you from being active regularly?

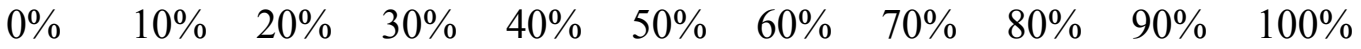

Not Confident at all Somewhat Confident Confident Very Confident

3. How confident are you that you can make up times when you have missed your regular physical activity?

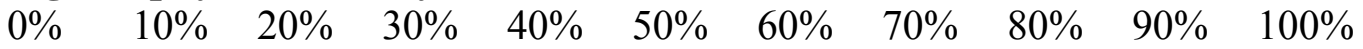

Not Confident at all Somewhat Confident Confident Very Confident 
B. When people are active, they expect to get some benefit from the activity. Please tell us how important the following benefits are to you when you are active.

1. It is fun.

2. It gives me time to think.

3. It helps me to relieve boredom.

4. It helps me to keep busy.

5. It helps to improve/maintain my skills.

6. It is competitive.

7. It is easy.

8. It makes me feel good.

9. It takes away my worries.

10. It allows me to be with friends.

11. It allows me to be part of a team or group.

12. It allows me to meet new people.

13. It gets me into shape.

14. It improves my health.

15. It improves my fitness. Not Important

$\begin{array}{ccccc}1 & 2 & 3 & 4 & 5 \\ \text { Not Important } & \text { Important } & \text { Very Important }\end{array}$

$\begin{array}{ccccc}1 & 2 & 3 & 4 & 5 \\ \text { Not Important } & \text { Important } & \text { Very Important }\end{array}$

$\begin{array}{ccccc}1 & 2 & 3 & 4 & 5 \\ \text { Not Important } & \text { Important } & \text { Very Important }\end{array}$

$\begin{array}{ccccc}1 & 2 & 3 & 4 & 5 \\ \text { Not Important } & \text { Important } & \text { Very Important }\end{array}$

$\begin{array}{lllll}1 & 2 & 3 & 4 & 5\end{array}$

$\begin{array}{ccccc}1 & 2 & 3 & 4 & 5 \\ \text { Not Important } & \text { Important } & \text { Very Important }\end{array}$

$\begin{array}{ccccc}1 & 2 & 3 & 4 & 5 \\ \text { Not Important } & \text { Important } & \text { Very Important }\end{array}$

$\begin{array}{ccccc}1 & 2 & 3 & 4 & 5 \\ \text { Not Important } & \text { Important } & \text { Very Important }\end{array}$

$\begin{array}{ccccc}1 & 2 & 3 & 4 & 5 \\ \text { Not Important } & \text { Important } & \text { Very Important }\end{array}$

$\begin{array}{ccccc}1 & 2 & 3 & 4 & 5 \\ \text { Not Important } & \text { Important } & \text { Very Important }\end{array}$

$\begin{array}{lllll}1 & 2 & 3 & 4 & 5\end{array}$

Not Important Important Very Important

$\begin{array}{ccccc}1 & 2 & 3 & 4 & 5 \\ \text { Not Important } & \text { Important } & \text { Very Important }\end{array}$

$\begin{array}{ccccc}1 & 2 & 3 & 4 & 5 \\ \text { Not Important } & \text { Important } & \text { Very Important }\end{array}$

$\begin{array}{ccccc}1 & 2 & 3 & 4 & 5 \\ \text { Not Important } & \text { Important } & \text { Very Important }\end{array}$

$\begin{array}{ccccc}1 & 2 & 3 & 4 & 5 \\ \text { Not Important } & \text { Important } & \text { Very Important }\end{array}$ 
16. It improves my appearance.

17. It makes me look cool. $\begin{array}{ccccc}1 & 2 & 3 & 4 & 5 \\ \text { Not Important } & \text { Important } & \text { Very Important }\end{array}$

$\begin{array}{ccccc}1 & 2 & 3 & 4 & 5 \\ \text { Not Important } & \text { Important } & \text { Very Important }\end{array}$

C. Sometimes when we are not as active as we would like to be, there are reasons. How important are the following factors in contributing to you not being active and how often did they occur in the last month?

1. I felt lazy.

2. I didn't feel like it.

How Often? $\square$ Never
12

Not Important

$\neg$ Twice

12

Not Important

$\square$ Twice

1

Not Important

$\square$ Twice

1

Not Important

$\square$ Twice

3
Important

$\square$ Three

(1)

$\begin{array}{ccc}3 & 4 & 5 \\ \text { Important } & \text { Very Important }\end{array}$

$\square$ Three

$\square$ Four or more

3. It makes me look uncool.

How Often? $\quad \square$ Never
4. I didn't have the money.

How Often? $\square$ Never

$\square$ Once

5. The activity is not close to my home.

\section{1}

Not Important

How Often? $\square$ Never

$\square$ Once

$\square$ Twice

$\begin{array}{lc}1 & 2 \\ \text { Not Important }\end{array}$

6. I couldn't get a ride.

How Often? $\square$ Never

$\square$ Once

7. I didn't have enough time.

How Often? $\square$ Never

$\square$ Once

8. I had too much homework.

How Often? $\square$ Never

$\square$ Once

$\square$ Twice

$\begin{array}{lr}1 & 2 \\ \text { Not Important }\end{array}$

$\square$ Twice

$\begin{array}{lr}1 & 2 \\ \text { Not Important }\end{array}$

$\square$ Twice

$\square$ Three $\begin{array}{cc}4 & 5 \\ \text { Very } & \text { Important }\end{array}$

$\square$ Four or more

\section{.}




\begin{tabular}{|c|c|c|c|c|c|}
\hline \multicolumn{3}{|c|}{ 9. It interferes with my social life. } & $\begin{array}{lc}1 & 2 \\
\text { Not Important }\end{array}$ & $\begin{array}{c}3 \\
\text { Important }\end{array}$ & $\begin{array}{cc}4 & 5 \\
\text { Very Important }\end{array}$ \\
\hline How Often? & $\square$ Never & $\square$ Once & $\square$ Twice & $\square$ Three & $\square$ Four or more \\
\hline \multirow{2}{*}{\multicolumn{3}{|c|}{ 10. I was injured. }} & $1 \quad 2$ & 3 & $4 \quad 5$ \\
\hline & & & Not Important & Important & Very Important \\
\hline How Often? & $\square$ Never & $\square$ Once & $\square$ Twice & $\square$ Three & $\square$ Four or more \\
\hline \multirow{2}{*}{\multicolumn{3}{|c|}{ 11. The weather was bad. }} & $1 \quad 2$ & 3 & $4 \quad 5$ \\
\hline & & & Not Important & Important & Very Important \\
\hline How Often? & $\square$ Never & $\square$ Once & $\square$ Twice & $\square$ Three & $\square$ Four or more \\
\hline \multirow{2}{*}{\multicolumn{3}{|c|}{ 12. The equipment was broken. }} & $1 \quad 2$ & 3 & $4 \quad 5$ \\
\hline & & & Not Important & Important & Very Important \\
\hline How Often? & $\square$ Never & $\square$ Once & $\square$ Twice & $\square$ Three & $\square$ Four or more \\
\hline \multirow{2}{*}{\multicolumn{3}{|c|}{ 13. I had family obligations. }} & $1 \quad 2$ & 3 & $4 \quad 5$ \\
\hline & & & Not Important & Important & Very Important \\
\hline How Often? & $\square$ Never & $\square$ Once & $\square$ Twice & $\square$ Three & $\square$ Four or more \\
\hline \multirow{2}{*}{\multicolumn{3}{|c|}{ 14. The area was not safe. }} & $1 \quad 2$ & 3 & $4 \quad 5$ \\
\hline & & & Not Important & Important & Very Important \\
\hline How Often? & $\square$ Never & $\square$ Once & $\square$ Twice & $\square$ Three & $\square$ Four or more \\
\hline \multirow{2}{*}{\multicolumn{3}{|c|}{ 15. It was too crowded. }} & $1 \quad 2$ & 3 & $4 \quad 5$ \\
\hline & & & Not Important & Important & Very Important \\
\hline How Often? & $\square$ Never & $\square$ Once & $\square$ Twice & $\square$ Three & $\square$ Four or more \\
\hline
\end{tabular}

\section{The following questions deal with your friends and family and their physical activity habits. Please tell us how often the following statements pertain to you.}

1. In the last month how often did you see any of your family members (mother, father, brothers, sisters, grandparents) participate in physical activity?
1 2
3
Sometimes
4
Often Very Often

2. In the last month, how often did you see any of your friends participate in physical activity?
1 2
3
Almost Never
Sometimes
Often
Very Often 
The following questions deal with reinforcement you may or may not receive from your family and friends. Please tell us how often the following statements pertain to you.

1. In the past month, how often did any of your family members say that you were good in the physical activities that you did?

$\begin{array}{lcccc}1 & 2 & 3 & 4 & 5 \\ \text { Never } & \text { Almost Never } & \text { Sometimes } & \text { Often } & \text { Very Often }\end{array}$

2. In the past month, how often did any of your family members get upset about the physical activities that you did?

$\begin{array}{lccrc}1 & 2 & 3 & 4 & 5 \\ \text { Never } & \text { Almost Never } & \text { Sometimes } & \text { Often } & \text { Very Often }\end{array}$

3. In the past month, how often did any of your friends say that you were good in the physical activities that you did?

$\begin{array}{ccccc}1 & 2 & 3 & 4 & 5 \\ \text { Never } & \text { Almost Never } & \text { Sometimes } & \text { Often } & \text { Very Often }\end{array}$

The following questions deal with support you may or may not receive from your family. Please tell us how often the following statements pertain to you.

1. In the past month, how often did any of your family members say that physical activity was good for you?

$\begin{array}{ccccc}1 & 2 & 3 & 4 & 5 \\ \text { Never } & \text { Almost Never } & \text { Sometimes } & \text { Often } & \text { Very Often }\end{array}$

2. In the past month, how often did any of your family members offer to be active with you?

$\begin{array}{lcccc}1 & 2 & 3 & 4 & 5 \\ \text { Never } & \text { Almost Never } & \text { Sometimes } & \text { Often } & \text { Very Often }\end{array}$

3. In the past month, how often did any of your family members order you to be active?

$\begin{array}{ccccc}1 & 2 & 3 & 4 & 5 \\ \text { Never } & \text { Almost Never } & \text { Sometimes } & \text { Often } & \text { Very Often }\end{array}$

4. In the past month, how often did any of your family members provide financial support (e.g., paid for equipment, the program, etc.) to help you be active? 1 Never 2 Almost Never Sometimes $\begin{array}{cc}4 & 5 \\ \text { Often } & \text { Very Often }\end{array}$

5. In the past month, how often did any of your family members help you learn/improve the skills that you use in being active?
1
2
3
Almost Never
Sometimes
Often Very Often 
6. In the past month, how often did any of your family members come to watch you when you were doing physical activity?

$\begin{array}{lccrc}1 & 2 & 3 & 4 & 5 \\ \text { Never } & \text { Almost Never } & \text { Sometimes } & \text { Often } & \text { Very Often }\end{array}$

7. In the past month, how often did any of your family members give you encouragement to stick with your physical activity program?

$\begin{array}{lccrc}1 & 2 & 3 & 4 & 5 \\ \text { Never } & \text { Almost Never } & \text { Sometimes } & \text { Often } & \text { Very Often }\end{array}$

8. In the past month, how often did any of your family talk to you about how much fun physical activity is?

$\begin{array}{lccrc}1 & 2 & 3 & 4 & 5 \\ \text { Never } & \text { Almost Never } & \text { Sometimes } & \text { Often } & \text { Very Often }\end{array}$

The following questions deal with support you may or may not receive from your friends. Please tell us how often the following statements pertain to you.

1. In the past month, how often did any of your friends say that physical activity was good for you?

$\begin{array}{ccccc}1 & 2 & 3 & 4 & 5 \\ \text { Never } & \text { Almost Never } & \text { Sometimes } & \text { Often } & \text { Very Often }\end{array}$

2. In the past month, how often did any of your friends offer to be active with you?

$\begin{array}{lcccc}1 & 2 & 3 & 4 & 5 \\ \text { Never } & \text { Almost Never } & \text { Sometimes } & \text { Often } & \text { Very Often }\end{array}$

3. In the past month, how often did any of your friends force you to be active?

$\begin{array}{llllr}1 & 2 & 3 & 4 & 5\end{array}$

Never Almost Never Sometimes Often Very Often

4. In the past month, how often did any of your friends help you learn/improve the skills that you use in being active?

$\begin{array}{lccrc}1 & 2 & 3 & 4 & 5 \\ \text { Never } & \text { Almost Never } & \text { Sometimes } & \text { Often } & \text { Very Often }\end{array}$

5. In the past month, how often did any of your friends come to watch you when you were doing physical activity?
1
2
3
Never
Almost Never
Sometimes
4
Often 
6. In the past month, how often did any of your friends give you encouragement to stick with your physical activity program?

$\begin{array}{lcccc}1 & 2 & 3 & 4 & 5 \\ \text { Never } & \text { Almost Never } & \text { Sometimes } & \text { Often } & \text { Very Often }\end{array}$

7. In the past month, how often did any of your friends talk to you about how much fun physical activity is?

1

Never

Almost Never

$\stackrel{3}{\text { Sometimes }}$

$\begin{array}{cc}4 & 5 \\ \text { Often } & \text { Very Often }\end{array}$

E. The following questions deal with the environment you live in.

1. Please circle the number of the items you have in your home, yard, or apartment complex.
1. Stationary aerobic equipment (e.g.
9. Sports equipment (balls, racquets) treadmill, stair climber)
10. Snowboard
2. Bicycle
11. Canoe, row boat, kayak
3. Trampoline
12. Skis (snow or water)
4. Running shoes
13. Basketball hoop
5. Swimming pool
14. Backyard rink
6. Weight lifting equipment (e.g., free weights, Nautilus, Universal)
7. Step aerobics, slide aerobics
8. Skates (roller, in line, or ice)

2. Please circle the number of any of the following that apply to your neighborhood.

1. Sidewalks

2. Heavy traffic

3. Hills

4. Street lights

5. Dogs that are unattended
6. Enjoyable scenery/Parks

7. Frequently see people walking or exercising

8. High crime

3. How safe do you feel walking in your neighborhood during the day?

$\begin{array}{lcccc}1 & 2 & 3 & 4 & 5 \\ \text { Very Unsafe } & \text { Somewhat Unsafe } & \text { Safe } & \text { Somewhat Safe } & \text { Very Safe }\end{array}$

4. Given that you can get to the physical activity or program, how safe do you feel getting to and from the program?

$\begin{array}{lcccc}1 & 2 & 3 & 4 & 5 \\ \text { Very Unsafe } & \text { Somewhat Unsafe } & \text { Safe } & \text { Somewhat Safe } & \text { Very Safe }\end{array}$


5. For each of these places where you can exercise, please circle its number if it is on a frequently traveled route (e.g., to and from school) or within a 5-min drive from your school or home.

1. Fitness facility

2. Basketball court

3. Bike lane or trails

4. Golf course

5. Playing field (soccer, football, softball etc.)
6. Public park

7. Running track

8. Skating rink

9. Swimming pool

10. Walking/hiking trails

11. Tennis courts

12. Dance studio

\section{Now we would like to ask you questions about you and your health. Please remember, you have the option to leave a question blank if you do not feel comfortable answering it.}

Please tell us some basic information about yourself.
1. Gender
A. Female
B. Male

2. Age. How old will you be at your next birthday?
A. 11
B. 12
C.13
D. 14
E.15
F.16
G.17
H.18 or older

3. Please write your home address and postal code here:

**Please note that we will not use this information to contact you or your parents in any way**

4. How long have you lived at this address?

5. How well are you doing in school this year?
A. Above average
B. Average
C. Below average

6. This year, where have most of your marks been?
A. $90 \%$ or higher
B. $80-89 \%$
C. $70-79 \%$
D. $60-69 \%$
E. $50-59 \%$
F. $49 \%$ or lower 
The next few questions ask about your family: Please circle the appropriate answer.

1. Who do you presently live with?
A. Both parents (biological or adopted)
B. Mother only
C. Father only
D. Other family members (e.g., a grandparent, etc.)
E. Alone
F. With friends
G. Room and board
H. Group home or foster home
I. Other

2. How many brothers and sisters do you have living with you?
A. None
B. 1
C. 2
D. 3
E. 4
F. 5
G. 6
H. 7 or more

3. Tell us about your father's work. Is he:
A. Working full time
B. Working part time
C. Works only at certain times of the year
D. Working at home (not looking for paid work)
E. Unemployed, but looking for work
F. Don't Know or Doesn't Apply
G. Other

4. Tell us about your mother's work. Is she:
A. Working full time
B. Working part time
C. Works only at certain times of the year
D. Working at home (not looking for paid work)
E. Unemployed, but looking for work
F. Don't Know or Doesn't Apply
G. Other

5. What is the highest level of schooling your father completed?
A. Less than high school
B. Finished high school
C. Trade school (for example, mechanic, technician, journeyman, librarian)
D. Some university
E. Finished university
F. Don't Know or Doesn't Apply
G. Other 
6. What is the highest level of schooling your mother completed?
A. Less than high school
B. Finished high school
C. Trade school (for example, mechanic, technician, journeyman, librarian)
D. Some university
E. Finished university
F. Don't Know or Doesn't Apply
G. Other

7. In comparison with other people your own age, would you describe your family's financial situation as (please choose only one answer):
A. Wealthy
B. Well-off
C. Comfortable
D. Adequate
E. Difficult
F. Poor
G. Don't Know

The next section asks about your own health practices: Please circle the appropriate answer. Please remember, you have the option to leave a question blank if you do not feel comfortable answering it.

1. In the last month, how often did you eat breakfast before you came to school?
A. 5 times a week
B. 3-4 times a week
C. 1-2 times a week
D. Seldom or never

2. In the last year, how often have you smoked cigarettes?
A. Never
B. Once a month or less
C. 2-3 times a month
D. 1-2 times a week
E. 3-4 times a week
F. Every day or almost every day

3. In the last year, how often have you drunk alcohol (beer, wine and hard liquor)?
A. Never
B. About once a month
C. 2-3 times a month
D. Once a week
E. 2-3 times a week
F. Every day 
4. In the last year, how often have you used other drugs such as marijuana, solvents, cocaine, LSD?
A. Never
B. 1-2 times
C. 3-9 times
D. 10 or more times

Tell us about your health: Please circle the appropriate answer.

1. Compared to others your age, how would you rate your health?
A. Excellent
B. Very good
C. Good
D. Fair
E. Poor

2. Are you limited in the kind and amount of physical activity that you can do because of a long-term (lasting for more than 6 months) physical problem or health problem?
A. Yes
B. No
C. Don't Know/Not Sure

3. In the past year have you had any of the following health problems (circle as many as apply):
A. Injury or poisoning
B. Breathing problems (asthma, chest infections, pneumonia)
C. Digestive problems (stomach or bowel trouble)
D. Trouble with my teeth or gums
E. Vision problems (trouble seeing)
F. Other serious health problems (for instance, cancer, heart problems, bladder problems, seizures etc.)
G. No health problems

4. What is your weight (pounds)?

5. How tall are you (feet and inches)?

6. This next question is about your weight. Choose the answer that is closest to how you feel:
A. I think I'm overweight (by about 5 pounds or more).
B. I think I'm underweight (by about 5 pounds or more).
C. I think my weight is okay. 
The next section contains statements about how you feel about yourself and your future.

For each statement, please state whether you never, seldom, sometimes, often, or always feel this way:

Never Seldom Sometimes Often
Always

$\begin{array}{llllllll}\text { 1. I have trouble making decisions. } & 1 & 2 & 3 & 4 & 5\end{array}$

$\begin{array}{lllllll}\text { 2. I like myself. } & 1 & 2 & 3 & 4 & 5\end{array}$

$\begin{array}{llllllll}\text { 3. I wish I was someone else. } & 1 & 2 & 3 & 4 & 5\end{array}$

4. I believe I can work things out by $\quad \begin{array}{llllll}1 & 2 & 3 & 4 & 5\end{array}$ myself if $I$ have a problem.

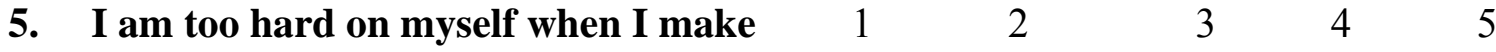
mistakes.

6. I like how I look. $\quad \begin{array}{llllll} & 1 & 2 & 3 & 4 & 5\end{array}$

7. I worry about what others think of me. $\quad 1 \quad 4 \begin{array}{lllll}2 & 3 & 4 & 5\end{array}$

8. I feel like an outsider. $\quad \begin{array}{lllllll}1 & 2 & 3 & 4 & 5\end{array}$

$\begin{array}{llllllll}\text { 9. I feel hopeful about my future. } & 1 & 2 & 3 & 4 & 5\end{array}$

10. In the last six months how often have you felt low or depressed?

A. More than 5 times

B. $2-5$ times

C. Once

D. Never

11. In the last six months how often have you had worries that kept you awake at night?
A. More than 5 times
B. $2-5$ times
C. Once
D. Never

Thank You For Your Time! 


\title{
Appendix D. Ethical Approval
}

\author{
UNIVERSITY OF
}

\author{
Certificate of Approval

\begin{tabular}{lll}
\hline PRINCIPAL INVESTIGATOR & DEPARTMENT & Beh \# \\
Karen Chad & Kinesiology & $02-688$
\end{tabular} \\ INSTITUTION(S) WHERE RESEARCH WILL BE CARRIED OUT \\ University of Saskatchewan \\ Saskatoon SK \\ STUDENT RESEARCHER(S) \\ Hang Lai \\ SPONSORING AGENCIES \\ CANADIAN INSTITUTES OF HEALTH RESEARCH (CIHR) \\ TITLE \\ Community Alliances for Health Research, Saskatoon In Motion: The Intrapersonal, social, and Environmental \\ Determinanats That Predict Continued Maintenance of Physical Activity and Lapses into Inactivity for Youth From Two \\ Diverse Geographic Areas \\ APPROVAL DATE $\quad$ EXPIRY DATE \\ 11-Dec-2002 31-Dec-2007 \\ APPROVAL OF \\ Have added Hang Lai as a student researcher. \\ APPROVED ON \\ 17-Apr-2007

\section{CERTIFICATION} \\ The University of Saskatchewan Behavioural Research Ethics Board has reviewed the proposed revisions to your study. \\ The revisions were found to be acceptable on ethical grounds. The principal investigator has the responsibility for any \\ other administrative or regulatory approvals that may pertain to this research project, and for ensuring that the authorized \\ research is carried out according to the conditions outlined in the original protocol submitted for ethics review. This \\ Certificate of Approval is valid for the above time period provided there is no change in experimental protocol or consent \\ process or documents.
}

Any significant changes to your proposed method, or your consent and recruitment procedures should be reported to the Chair for Research Ethics Board consideration in advance of its implementation.

ONGOING REVIEW REQUIREMENTS

In order to receive annual renewal, a status report must be submitted to the REB Chair for Board consideration within one month of the current expiry date each year the study remains open, and upon study completion. Please refer to the following website for further instructions: http://www.usask.ca/research/ethics_review/
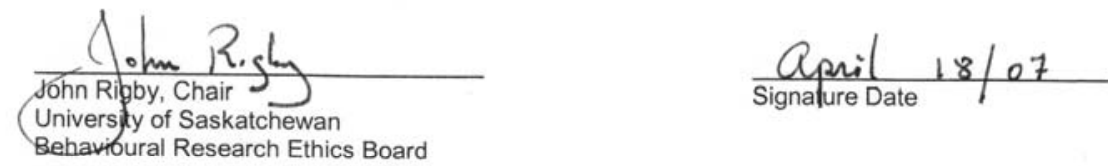

Behavibural Research Ethics Board

Please send all correspondence to: Ethics Office University of Saskatchewan Room 306 Kirk Hall, 117 Science Place

Saskatoon SK S7N 5 CB

Telephone: (306) 966-2084

Fax: (306) 966-2069 